\author{
UNIVERSIDADE DE SÃO PAULO \\ INSTITUTO DE ENERGIA E AMBIENTE \\ PROGRAMA DE PÓS-GRADUAÇÃO EM ENERGIA
}

TALITA DOS SANTOS ESTURBA

AVALIAÇÃO DO CONSUMO ENERGÉTICO EM OBRAS DE CONSTRUÇÃO CIVIL DE GRANDE PORTE 
TALITA DOS SANTOS ESTURBA

\section{AVALIAÇÃO DO CONSUMO ENERGÉTICO EM OBRAS DE CONSTRUÇÃO CIVIL DE GRANDE PORTE}

Dissertação apresentada ao Programa de PósGraduação em Energia da Universidade de São Paulo para obtenção do título de Mestre em Ciências.

Orientador: $\operatorname{Prof}^{\mathrm{a}} \operatorname{Dr}^{\mathrm{a}}$ Hirdan Katarina de Medeiros Costa

\section{Versão Corrigida}

(versão original disponível na Biblioteca da Unidade que aloja o Programa e na Biblioteca Digital de Teses e Dissertações da USP)

\section{SÃO PAULO \\ 2014}


Esturba, Talita dos Santos

Avaliação do Consumo Energético em Obras de Construção Civil de Grande Porte; orientadora Hirdan Katarina de Medeiros Costa. - São Paulo, 2014.

95f.: il.; $30 \mathrm{~cm}$.

Dissertação (Mestrado - Programa de Pós-Graduação em Energia) - Universidade de São Paulo.

1. Construção civil, 2. Combustíveis fósseis, 3. Uso final de energia. 
FOLHA DE APROVAÇÃO 


\section{DEDICATÓRIA}

Dedico aos anjos que tornaram este trabalho possível. Com saudosa lembrança. 


\section{AGRADECIMENTO}

A Deus, por ser minha fonte de força e inspiração nos momentos de dificuldade e grande provedor de alegria à nossa existência.

A todos os anjos que deram uma passada em minha vida para dar aquela força nos momentos difíceis.

Ao anjo não me deixou desistir por sequer nenhum minuto em todos os dias em que trabalhei neste projeto. Com certeza, sem Calvin Iost este trabalho não seria desenvolvido com as forças necessárias.

Ao anjo que me apoiou desde meu primeiro respirar, meu Pai, Humberto Esturba, que sempre valorizou a força que eu nunca vi em mim mesma. "Se fosse fácil, qualquer um faria".

Ao anjo que me criou e se foi, deixando um buraco no coração que nunca ninguém conseguirá fechar. Todos os valores de minha vida e o que sou hoje devo a ela, minha Avó-Mãe, Arminda Cézar, que descanse ao lado dos anjos em sua forma mais pura.

Aos professores do IEE/USP, que compartilharam seu conhecimento para fazer progredir mais uma geração de novos mestres e doutores.

À minha orientadora $\operatorname{Prof}^{\mathrm{a}}$ Dr $^{\mathrm{a}}$ Hirdan Katarina de Medeiros Costa, pela paciência e pelo apoio demonstrado durante a confecção deste trabalho.

A esta banca e à banca de minha qualificação, pelo tempo precioso que foi dispensado em suas agendas para apreciar este trabalho.

A toda equipe técnica e funcional do IEE, pelos apoios sempre que precisei.

Aos meus líderes no trabalho, pelo fornecimento de tempo, informações e condições necessárias para o bom andamento deste mestrado.

A todos, o meu "Muito obrigado". 


\section{EPÍGRAFE}

"Ainda que dizes que não o vês, a tua causa está diante dele; por isso, espera nele" (Jó 35; 14) 


\section{RESUMO}

ESTURBA, Talita dos Santos. Avaliação do Consumo Energético em Obras de Construção Civil de Grande Porte. . 2014. 95f. Dissertação (Mestrado em Ciências) Programa de Pós-Graduação em Energia - Instituto de Energia e Ambiente da Universidade de São Paulo, São Paulo, 2014.

O presente trabalho visa analisar, a partir da perspectiva do uso final de energia, os resultados do indicador de eficiência criado para averiguar o desempenho de equipamentos usados em obras de construção civil de grande porte. Dentro do setor apreciado, optou-se por analisar energeticamente apenas a fase de construção per si em razão desta etapa ser uma fase de intenso consumo energético. O presente trabalho contou com uma compilação de dados baseados no consumo de 26.121 equipamentos em operação, em 84 obras de construção de grande porte. A partir do banco de dados inicial realizou-se a análise dos dados dos equipamentos monitorados via satélite e com informações de eficiência. Por fim, estimou-se, especificamente, a variação da eficiência nos equipamentos em questão. $\mathrm{Na}$ busca de resultados, foi possível constatar uma predominância no consumo de óleo diesel quando comparado a outros insumos energéticos. Geradores, guindastes, compressores e caminhões foram os itens que apresentaram maiores índices de eficiência, com 99,0\%, 93,5\%, 93,2\% e 92,3\%, respectivamente. Esses resultados mostram que a maior parte destes equipamentos operam próximo ao ótimo do consumo por hora registrado no projeto.

Palavras-chave: Construção civil, Combustíveis fósseis, Uso final de energia. 


\begin{abstract}
ESTURBA, Talita dos Santos. Energy Consumption Evaluation of Construction Works of Large Size. 2014. 95f. . Master's Dissertation - Graduate Program on Energy, Universidade de São Paulo, São Paulo, 2014.
\end{abstract}

The present work aims to analyze, from the perspective of the end use of energy, the results of the efficiency indicator created in order to investigate the performance of a group of equipment widely used in large construction projects in Brazil. The analyze comprehends only construction period itself due this step is to consider a phase of intense energy consumption. This work included a database related to the fuel consumption of 26,121 equipment during their operation, at 84 work sites in the large construction projects. From the database described, we performed data analysis of satellite equipment monitored and with efficiency information. Finally, it was estimated the variation of efficiency of the equipment in question. The results show a predominance of diesel consumption when compared to other fuels inputs. Considering our methodology, generators, cranes, compressors and trucks were the items that had higher levels of efficiency, with $99.0 \%$, 93.5\%, 93.2\% and 92.3\%, respectively. These results show that most of these devices operate close to the optimal consumption per hour recorded in the project.

Keywords: Large construction projects, Fossils fuels, Efficiency in energy end-use. 


\section{LISTA DE FIGURAS}

Figura 1 - Taxa de crescimento do PIB brasileiro frente ao valor acrescentado bruto (VAB) pelo setor de construção civil

Figura 2 - Participação relativa realizada em 2013 e prevista para 2017 e 2022 do PIB

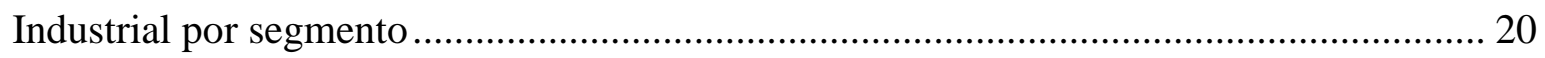

Figura 3 - Evolução do consumo energético per capita . ................................................. 25

Figura 4 - Esquematização simplificada do Ciclo de Vida da Construção Civil................ 29

Figura 5 - Participação energética durante a vida útil de edificações. ............................... 30

Figura 6 - Principais fases de um projeto de construção. ................................................. 31

Figura 7 - Classificação da abrangência do EROI............................................................ 37

Figura 8 - Metodologia de classificação da o indicador de eficiência.............................. 52

Figura 9 - Energia consumida durante a construção [GJ]. ............................................ 57

Figura 10 - Consumo energético por tipo de equipamento no ano de 2011 para o total de

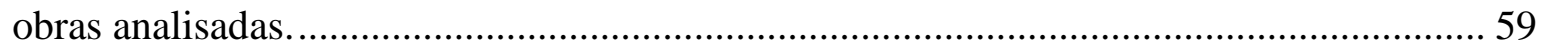

Figura 11 - Porcentagem acumulada de consumo energético por tipo de equipamento. ... 60

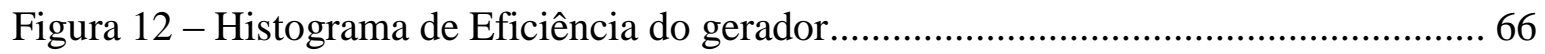

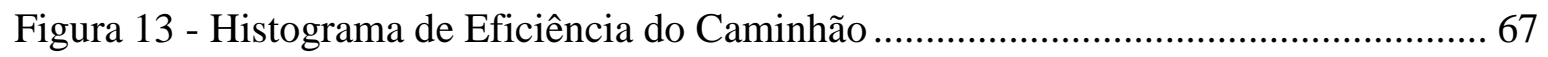

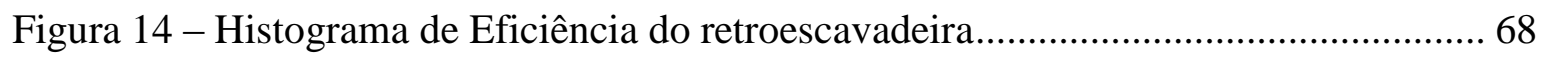




\section{LISTA DE TABELAS}

Tabela 1 - Participação setorial no PIB 18

Tabela 2 - Valores usuais de EROI para diversos recursos energéticos 38

Tabela 3 - Quantitativos de obras da "Empresa X" no período entre janeiro e dezembro de 2011 46

Tabela 4 - Uniformização dos dados por base energéticas 47

Tabela 5 - Método de desagregação de equipamentos utilizados neste estudo frente aos usos finais estabelecidos pelo BEU. 50

Tabela 6- Parâmetros para análise de incerteza para o consumo de combustíveis. 54

Tabela 7 - Destinação da energia para cada uso final 61

Tabela 8 - Parâmetros para classificação de indicador de eficiência calculado 62

Tabela 9 - Potencial de redução com base no indicador de eficiência criado 65

Tabela 10 - Consolidação dos resultados 68

Tabela 11 - Total de combustíveis consumidos durante a construção de Hidrelétricas no ano de 2011 dentro da base de dados utilizada. 69

Tabela 12 - Estimativa do total de energia gerada durante a vida útil dos projetos em questão 70 


\section{LISTA DE SIGLAS}

ABNT - Associação Brasileira de Normas Técnicas

ACV - Análise de Ciclo de Vida

ANP - Agência Nacional do Petróleo, Gás Natural e Biocombustíveis

APUC - Advanced Procurement for Universities and Colleges

BEN - Balanço Energético Nacional

BEU - Balanço de Energia Útil

BX - Percentual de biodiesel no combustível

CDP - Carbon Disclosure Project

CIMA - Conselho Interministerial do Açúcar e do Álcool

CNAE - Classificação Nacional de Atividades Econômicas

DIEESE - Departamento Intersindical de Estatística e Estudos Socioeconômicos

DOU - Diário Oficial da União

EF - Energia Final

ENR - Energia não Recuperável

EP - Energia Perdida

EPA - Environmental Protection Agency

EPE - Empresa de Pesquisa Energética

EPEc - Energia com Potencial de Economia

EROI - Retorno Sobre o Investimento de Energia

EU - Energia Útil

EY - Percentual de etanol no combustível

GJ - Gigajoule (corresponde a $10^{9}$ joules)

GLP - Gás Liquefeito de Petróleo

$\mathrm{H}$ - Hora 
Hab - Habitantes

IBGE - Instituto Brasileiro de Geografia e Estatística

IEA - International Energy Agency

IPCC - Intergovernmental Panel on Climate Change

IPIECA - International Petroleum Industry Environmental Conservation

\section{Association}

IPPC - Integrated Pollution Prevention and Control

ISO - International Organization for Standardization

Kcal - Quilocalorias (corresponde a $10^{3}$ calorias)

$\mathrm{Kg}$ - Quilograma (corresponde a $10^{3}$ gramas)

KWh - Quilowatt hora (corresponde a $10^{3}$ watts hora)

L - Litros

MAPA - Ministério de Estado da Agricultura, Pecuária e Abastecimento

MAPA - Ministro de Estado da Agricultura, Pecuária e Abastecimento

MAPEE - Modelo para a Avaliação do Potencial de Economia de Energia

MME - Ministério de Minas e Energia

MWh - Megawatt hora (corresponde a $10^{6}$ watts hora

NCAUR - National Renewable Energy Laboratory

PCI - Poder Calorífico Inferior

PIB - Produto Interno Bruto

UNEP - United Nations Environment Programme

VAB - Valor Acrescentado Bruto 


\section{LISTA DE EQUAÇÕES}

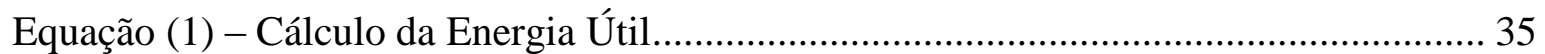

Equação (2) - Cálculo da Energia Perdida.............................................................................. 35

Equação (3) - Cálculo da Massa de combustível.............................................................. 49

Equação (4) - Cálculo do Consumo Energético de combustíveis ........................................ 49

Equação (5) - Cálculo do Indicador de Eficiência............................................................ 52 


\section{SUMÁRIO}

$1 \quad$ Introdução 17

$\begin{array}{lll}1.1 & \text { Panorama energético atual } & 17\end{array}$

1.2 Construção civil como indústria 18

1.3 Problemática 21

1.4 Hipóteses 21

1.5 Objetivos 22

$\begin{array}{lll}1.6 & \text { Estrutura capitular do trabalho } & 22\end{array}$

2 Revisão Bibliográfica 24

2.1 Introdução 24

2.2 Análise energética 24

2.3 Ciclo de Carnot 26

2.4 Impacto da construção civil na vida útil de um projeto 27

2.5 Problemática energética na etapa de construção 32

2.6 Balanço de energia útil para análise da relevância energética dos insumos 34

2.7 Análise do Retorno Sobre o Investimento de Energia 36

2.8 Combustíveis 39

2.9 Análise de incertezas 41

2.10 Considerações finais do capítulo 42

3 Método 44

3.1 Introdução 44

3.2 Banco de dados 44

3.3 Dados utilizados nos cálculos 46

3.4 Métodos de coleta da Informação 47

3.5 Análise energética 48

3.6 Utilização do balanço de energia útil (BEU) 50

3.7 Construção de parâmetros para classificação de indicador de eficiência 51

3.8 Análise de incertezas 53

3.9 Utilização de EROI na análise de hidrelétricas 54

3.10 Considerações finais do capítulo 55

4 Resultados e Discussões 56

$\begin{array}{lll}4.1 & \text { Introdução } & 56\end{array}$ 
4.2 Insumos energéticos 56

4.3 Demanda energética nos diferentes usos 58

$\begin{array}{lll}4.4 & \text { Destinação da energia } & 61\end{array}$

4.5 Classificação do indicador de eficiência 61

4.6 Potencial de redução de consumo com base no indicador de eficiência criado 64

$\begin{array}{lll}4.7 & \text { Análise do EROI } & 68\end{array}$

$\begin{array}{lll}4.8 & \text { Considerações finais do capítulo } & 70\end{array}$

5 Conclusão 72

6 Apêndices 81

6.1 Consumo por equipamentos 81

6.2 Consumo por tipo de caminhão 82

6.3 Consumo energético por tipo de equipamento [GJ] 83

6.4 Consumo energético por tipo de caminhão [GJ] 84

6.5 Destinação dos combustíveis para cada tipo de equipamento [Litros] 85

6.6 Destinação dos combustíveis para cada tipo de equipamento [GJ] 86

6.7 Destinação dos combustíveis para cada tipo de equipamento [\% de litros] 87

6.8 Destinação dos combustíveis por tipo de obra [GJ] 88

6.9 Participação no consumo energético de combustíveis para cada tipo de obra [\% de GJ] 90

6.10 Consumo mediano por tipo de equipamento monitorado via satélite $[1 / \mathrm{h}] \quad 92$

6.11 Quantitativo de geradores por faixa de consumo em litros por hora [unidades] 93

6.12 Quantitativo de caminhões por faixa de consumo em litros por hora [unidades]94

6.13 Quantitativo de retroescavadeiras por faixa de consumo em litros por hora

[unidades] 95 


\subsection{Panorama energético atual}

A energia é vital para o desenvolvimento, crescimento e manutenção do atual estilo de vida da sociedade moderna. Logo, suas fontes devem ser protegidas, preservadas e seu uso deve ser planejado (GOLDEMBERG, 1998a).

Goldemberg (1998a) considera que a energia é um dos fatores primordiais para o livre desenvolvimento de uma comunidade ou de uma nação.

Considerada em suas dimensões técnica, econômica, ambiental e social, a energia apresenta relevância no aspecto produtivo das organizações, que podem melhorar sua gestão de energia gerando ganhos na sua utilização e no aumento de eficiência (ISO, 2011).

Melhorias na eficiência energética são prioridades para diversos países devido a preocupações com emissões de gases de efeito estufa, a estratégias políticas relacionadas a reduções no consumo de combustíveis finitos, tais como os fósseis, assim como em razão dos objetivos direcionados a garantia da segurança de fornecimento de energia (IPPC, 2009).

Desta forma, é importante conceituar eficiência energética. Segundo a ABNT (2011), esta é a razão ou outra relação quantitativa entre uma saída de desempenho, serviços, produtos ou energia e uma entrada de energia. Ressaltando a importância de entradas e saídas serem claramente especificadas e mensuráveis em quantidade e qualidade.

Melhorias de eficiência ocorrem de forma eficaz quando são implantados programas de eficiência energética. Estes visam reduzir a energia necessária para o atendimento das demandas da sociedade por serviços energéticos tais como iluminação, aquecimento, resfriamento, acionamento, transportes e processuais (MME, 2011).

Diante desse panorama, vários setores da economia encontram motivações e desafios para aprimorar suas atividades produtivas, incluindo a utilização de programas de eficiência energética. 
O setor de construção civil de grande porte destaca-se com elevado consumo energético (UNEP, 2007) e em expansão no Brasil, com crescimento do PIB setorial verificado de 11,6\%, em 2009 (DIEESE, 2012).

Infere-se, portanto, que a descrição, a compreensão e a discussão sobre caminhos de alcançar e de aprimorar a eficiência energética nesse setor merecem estudo e análise específica, conforme delineado no item 1.2.

\subsection{Construção civil como indústria}

A proposta do presente trabalho se restringe à análise do setor de construção civil por se tratar, conforme já dito, de um campo com elevado consumo energético (UNEP, 2007).

No caso do Brasil, considerando o período de 2004 para 2005, os gastos com o setor de construção civil cresceram 800\% (UNEP, 2007).

Também no Brasil, a indústria da construção representa uma parcela representativa dentro do PIB (Produto Interno Bruto) nacional, conforme apresentado pela Tabela 1 que sintetiza as projeções decenais relativas e médias em classificação por setor na economia e na indústria. Como parâmetro de comparação, inclui-se a evolução quinquenal no período de 2002 a 2011.

Como se percebe, a Tabela 1 mostra a relevante participação da construção civil na indústria, com destaque para o histórico de 18,5\% (2002-2006) e 19,6\% (2006-2011), assim como para as projeções de crescimento de 21,8\% (2013-2017) e 21,9\% (2018-2022).

Tabela 1 - Participação setorial no PIB

\begin{tabular}{|c|c|c|c|c|}
\hline \multirow{2}{*}{ Setor } & \multicolumn{2}{|c|}{ Histórico } & \multicolumn{2}{|c|}{ Projeção } \\
\hline & $2002-2006$ & 2007-2011 & 2013-2017 & $2018-2022$ \\
\hline \% PIB na Indústria & 100,0 & 100,0 & 100,0 & 100,0 \\
\hline Extrativa mineral & 9,8 & 10,4 & 12,8 & 14,7 \\
\hline Transformação & 61,0 & 58,6 & 53,7 & 51,4 \\
\hline Construção Civil & 18,5 & 19,6 & 21,8 & 21,9 \\
\hline $\begin{array}{l}\text { Produção e distribuição de água, } \\
\text { eletricidade e gás }\end{array}$ & 10,7 & 11,4 & 11,7 & 12,0 \\
\hline
\end{tabular}

Fonte: baseado em MME; EPE, 2013. 
A Figura 1 traz um comparativo, no período de 2000 a 2012, entre a taxa de crescimento do PIB do Brasil a preço base (incluindo impostos) e o Valor Acrescentado Bruto a Preços de Mercado (VABpb) da construção civil, entendendo-se como a receita de venda deduzida dos custos dos recursos adquiridos de terceiros. É, portanto, o quanto o setor contribuiu para a formação do Produto Interno Bruto (PIB) do país.

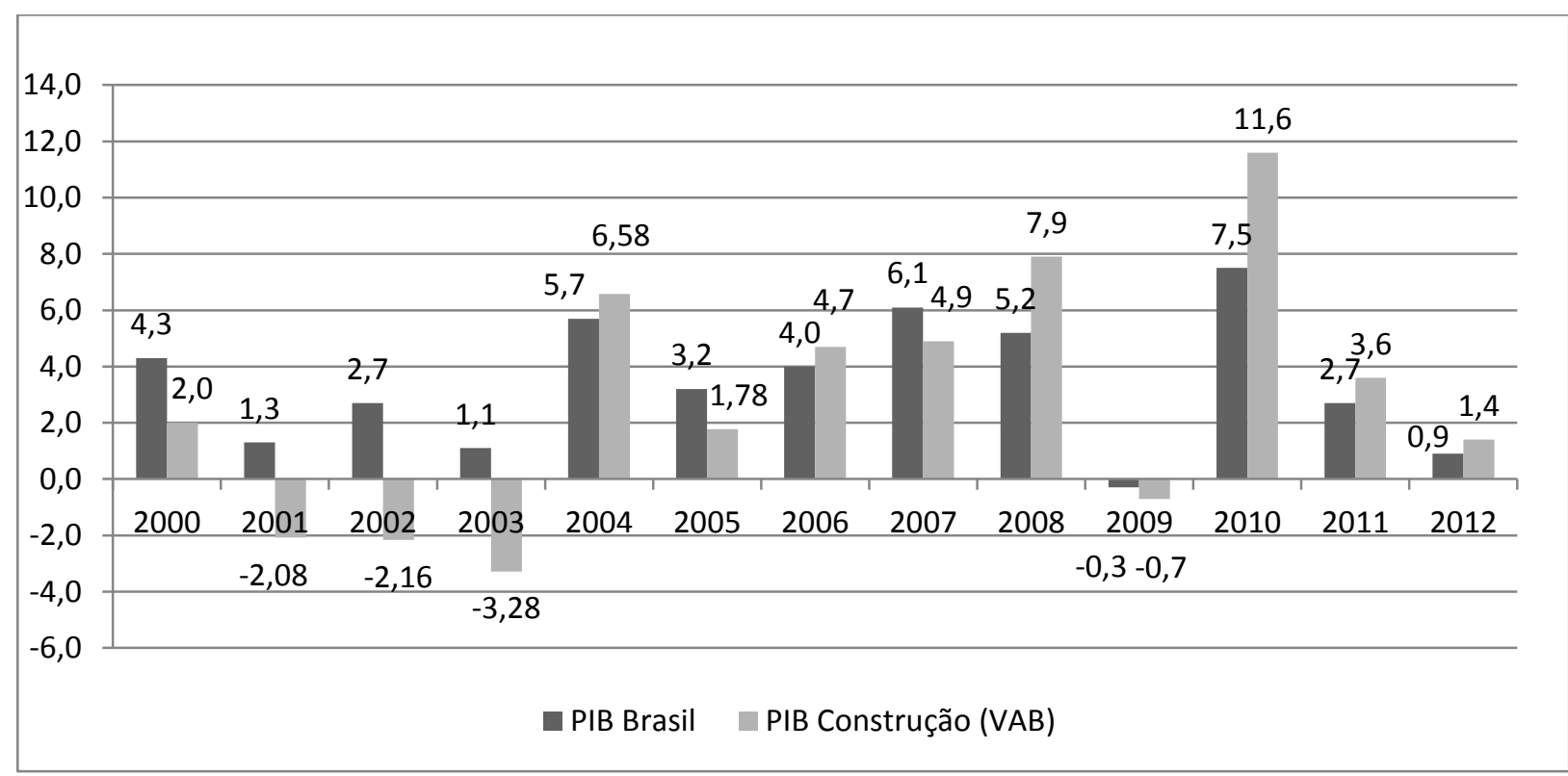

Figura 1 - Taxa de crescimento do PIB brasileiro frente ao valor acrescentado bruto (VAB) pelo setor de construção civil

Fonte: DIEESE - Departamento Intersindical de Estatísticas e Estudos Socioeconômicos, 2012.

Com relação à Figura 1, para o setor da construção civil observou-se em 2012 um crescimento superior à média nacional, com 1,4\% enquanto que o PIB nacional apresentou o valor de 0,9\% (DIEESE, 2012).

O grau de relevância da construção civil no PIB brasileiro em composição com outras áreas também pode ser observado na Figura 2 que mostra a evolução estimada no PIB brasileiro entre os anos de 2012 e 2022 pela indústria. 


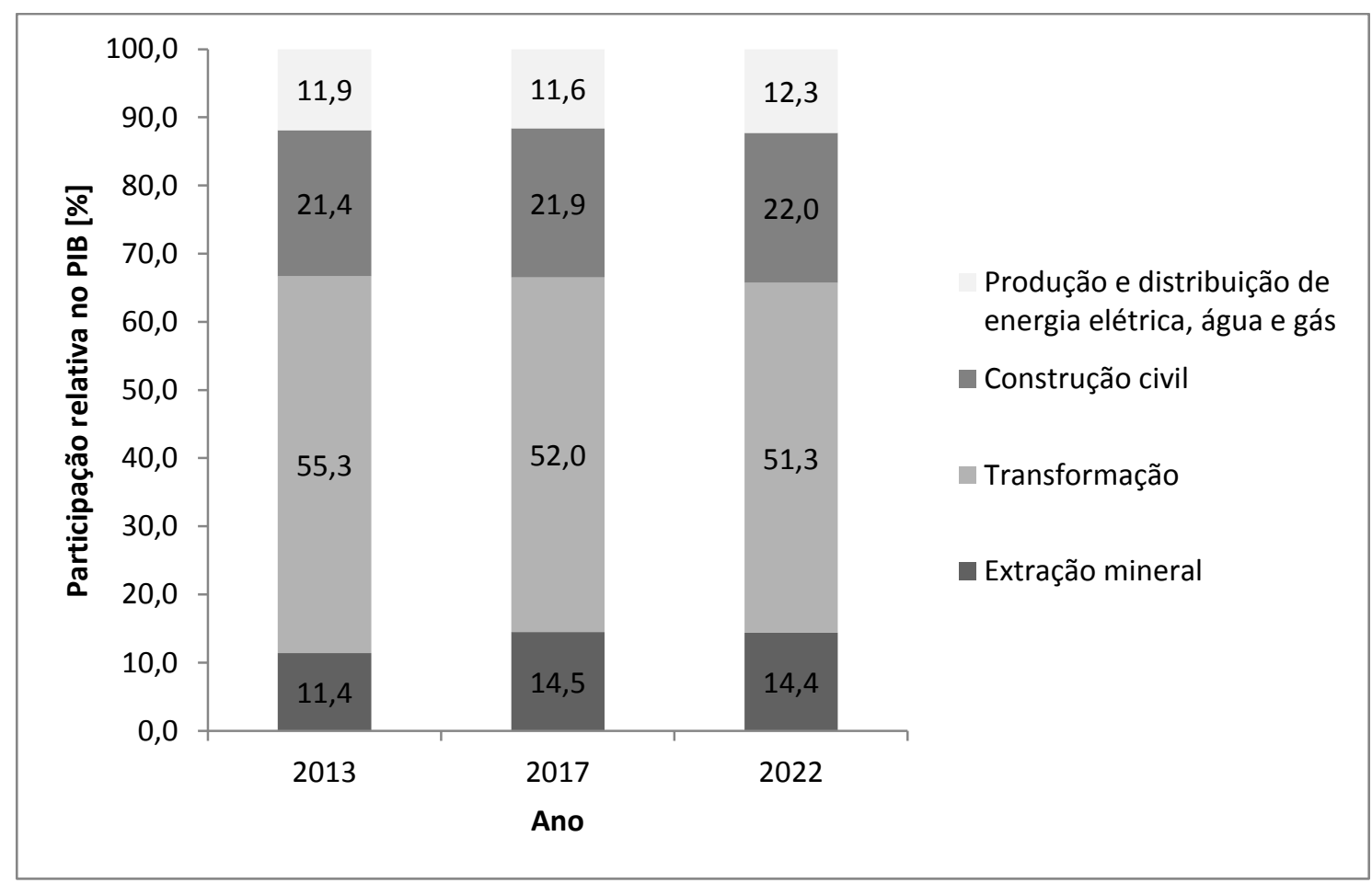

Figura 2 - Participação relativa do PIB Industrial por segmento, realizada em 2013 e prevista para 2017 e 2022.

Fonte: baseado em MME; EPE, 2013.

Conforme a Figura 2 verifica-se que a indústria de transformação vem perdendo gradualmente a participação em comparação aos outros segmentos, que apresentam uma expansão moderada.

Já a indústria extrativa mineral caracteriza-se pela produção de recursos naturais em que o Brasil apresenta vantagem comparativa considerável. A tendência é que esse setor cresça impulsionado pela demanda externa dos países emergentes e, para isso, as empresas têm feito pesados investimentos na exploração e produção de petróleo e na mineração. Para este setor projeta-se uma taxa de crescimento acima da média da indústria que se traduzirá em aumento da participação no valor adicionado setorial em 2022.

A produção e distribuição de eletricidade, de água e de gás crescem no ritmo médio da indústria como um todo e, como mostrado na Figura 2, manterá o mesmo nível de participação no valor adicionado da indústria. A construção civil apresentará um período de crescimento vinculado à expansão da infraestrutura e aos programas habitacionais governamentais. Além das obras para atender às demandas dos eventos esportivos, o setor será puxado pelo crescimento da infraestrutura (MME; EPE, 2013). 
Por essas razões a projeção de crescimento da construção civil foi mantida acima da média da indústria, com ganho de participação do setor.

Tal crescimento do setor de construção civil implica diretamente em um incremento do consumo energético para o setor e traz oportunidades de se estudar e de se propor caminhos para aprimorar processos em direção ao objetivo de aumento da eficiência energética desse setor.

\subsection{Problemática}

Considerando que o presente estudo vem de encontro com as necessidades atuais enfrentadas pela sociedade na redução de consumo energético em suas atividades, assim como em razão da importância de pesquisas acadêmicas para apoiar tomadas de decisões que foquem as práticas de uso racional de energia, apresenta-se a problemática desse trabalho: Quais as atividades da construção civil de grande porte que devem passar por processos de gestão direcionados à criação de programas focando o aprimoramento da eficiência energética?

\subsection{Hipóteses}

Para responder ao problema posto, serão analisados dados de forma a demonstrar as duas hipóteses a seguir.

A primeira baseia-se na relevância que o consumo de diesel apresenta dentro da construção civil, o que ocasiona uma tendência de atuação de gestão focada em melhorias no uso desse insumo para obter o aprimoramento da eficiência energética global do setor em questão.

A segunda hipótese tenta descrever e compreender os tipos de equipamentos que tem sua operação focada no consumo de diesel e, com isso, trabalhar com a gestão do insumo energético dentro da cadeia construtiva. 


\subsection{Objetivos}

\subsubsection{Objetivo Geral}

Considerando a problemática discutida, o objetivo principal do trabalho é apontar as atividades e tipos de equipamentos com maior potencial de redução de energia tendo por base o consumo de cada insumo energético utilizado em obras de construção civil de grande porte.

\subsubsection{Objetivos Específicos}

Em termos de objetivos específicos, o trabalho pretende alcançar as seguintes etapas:

- Levantar a distribuição dos insumos energéticos onde obras de construção detém a gestão de sua aplicação para cada tipo de uso final;

- Estimar os rendimentos energéticos correntes e os de referência utilizados para cada tipo de uso final;

- $\quad$ Estimar os coeficientes de destinação de energia;

- $\quad$ Estimar o potencial de economia de energia nos diferentes usos;

- Direcionar os usos que requerem maior atenção para a aplicação de boas práticas.

\subsection{Estrutura capitular do trabalho}

Além do presente capítulo introdutivo, a dissertação compreende quatro capítulos. O segundo capítulo traz a revisão bibliográfica, em que se descreve o estado da arte da construção civil de grande porte relacionado ao consumo energético.

O terceiro capítulo apresenta os métodos utilizados no trabalho, incluindo a ferramenta criada para análise de eficiência. O capítulo 4 expõe os resultados e discussões. E, finalmente, as conclusões são delineadas no capítulo 5.

O capítulo 0 traz as referências dos documentos utilizados para embasamento teórico do presente trabalho. O capítulo 6 traz apêndices com os principais dados brutos e processados utilizados. 
Todos os dados foram obtidos a partir da cessão de informações provenientes de empresa do setor de construção civil de grande porte, aqui denominada "Empresa X". Essas informações são as utilizadas para a gestão da construção, sendo as mesmas obtidas durante a operação dos equipamentos analisados.

No presente estudo de caso, decidiu-se não mencionar o nome da Empresa X para manter a integralidade e a neutralidade científicas, evitando-se qualquer tipo de propaganda e divulgação da Empresa que cedeu os dados.

Os dados serão avaliados ao final deste trabalho quanto a sua consistência. Não faz parte do objetivo do presente trabalho a análise do ciclo de vida de uma edificação, mas tão somente a análise energética de sua fase de construção. 


\section{Revisão Bibliográfica}

\subsection{Introdução}

A partir do objetivo descrito no Capítulo 1, a revisão bibliográfica realizada tem como objetivo a analise energética global do uso da energia na era moderna, trazendo um panorama geral dos conceitos de energia e eficiência energética.

Introduziu-se o Ciclo de Carnot para fundamentar a ferramenta criada no presente trabalho para a análise de eficiência dos equipamentos da construção civil de grande porte.

Explicados os conceitos norteadores do trabalho, concentrou-se a revisão bibliográfica na etapa de construção civil dentro da vida útil das edificações. Em seguida, averiguou-se o consumo energético dentro da construção civil pela investigação da literatura dessa área, em que o diesel foi apontado como principal combustível.

É apresentado o método do Balanço de Energia Útil (BEU) para obter a classificação dos diferentes usos finais da energia utilizada no setor. Com isso, foi encontrada a classificação de equipamentos por tipo. Também, para dar uma maior confiabilidade aos dados coletados, foi realizada uma análise de incertezas.

Esse capítulo, ainda, traz a revisão da literatura sobre o Retorno Sobre o Investimento de Energia (EROI) utilizado para analisar projetos que irão gerar energia e onde se espera que um retorno energético superior ao que foi inicialmente investido. Assim, a importância desse indicador seria delimitar valores mínimos de representatividade, e no caso de se alcançar uma economia de energia durante a fase de construção, pode tornar o projeto energeticamente mais interessante energeticamente.

\subsection{Análise energética}

A energia destaca-se, ao longo do tempo, como fator predominante para o crescimento e evolução da humanidade. Inicialmente, a abundância dos combustíveis fósseis norteou as formas de apropriação e de utilização desde sua descoberta racional pelo ser humano até a sua comercialização em escala mundial (GOLDEMBERG, 1998). 
Atualmente, existe um debate sobre a ameaça de escassez do combustível fóssil devido ao uso intensivo e, por que não dizer, também, desperdício, o que leva ao crescimento de esforços sociais e governamentais no que tange ao desenvolvimento e à viabilização de fontes energéticas renováveis (GOLDEMBERG, 1998).

Com o passar do tempo e com a evolução da sociedade, o homem vem aumentando seu consumo energético, em busca de conforto e comodidade. Na idade contemporânea, o consumo energético per capita ultrapassa qualquer valor antes visto na história humana, conforme Figura 3 (GOLDEMBERG, 1998b).

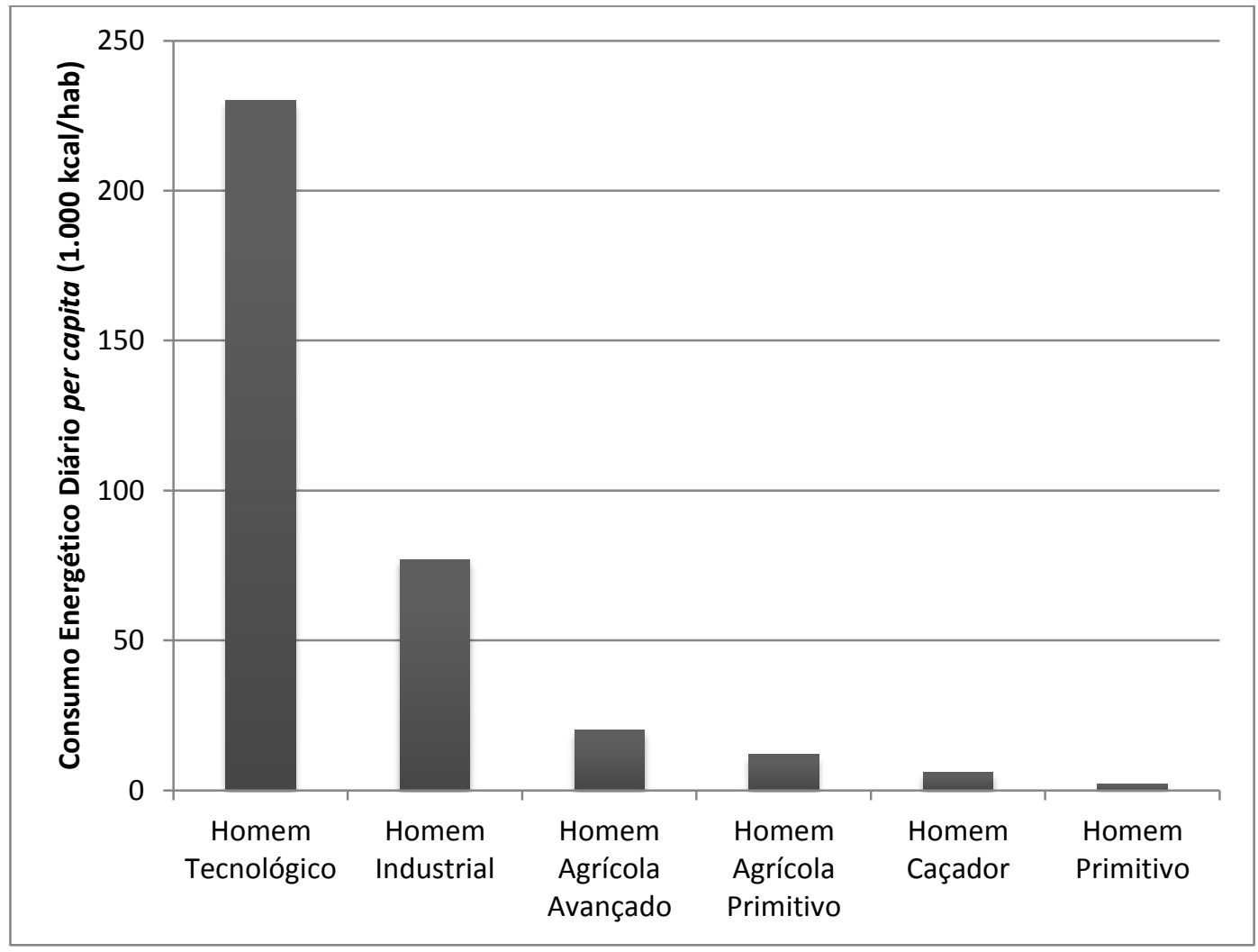

Figura 3 - Evolução do consumo energético per capita.

Fonte: Adaptado de GOLDEMBERG, 1998b.

Diante desse panorama de crescimento do consumo energético per capita, evidenciou-se o paralelismo entre consumo energético e uso de recursos naturais não renováveis, em que o homem tecnológico se apropria, sobretudo, de derivados de petróleo.

O consumo energético do homem tecnológico, descrito na Figura 3, desencadeou preocupações e iniciou um processo onde governos e corporações empenham-se em 
reduzir as emissões de gases de efeitos estufa e em realizar políticas de consumo racional de combustíveis fósseis (IPCC, 2006).

Dentre as políticas de consumo racional, destaca-se os programas de eficiência energética, cujo conceito é a razão entre energia útil e energia consumida pelo processo (PATTERSON 1996, 377 apud CURSINO, 2011).

Apesar de o conceito de eficiência energética usualmente empregado ser o difundido pelo Patterson (1996), o presente texto trabalha com diferentes máximos e mínimos para quantificar a eficiência, baseando-se no consumo energético apresentado por diversos equipamentos de um mesmo tipo, em casos práticos e sob operação na construção civil de grande porte.

\subsection{Ciclo de Carnot}

Esse item tem o objetivo de analisar as diferenças entre o ciclo de Carnot e a ferramenta criada para analisar a eficiência de equipamentos utilizados na construção civil de grande porte.

Um dos objetivos deste trabalho é a criação de uma escala com base nos dados amostrais, a partir de várias informações de eficiência para o mesmo tipo de equipamento, utilizando-se a definição de ideal como o maior valor de eficiência atingido por aquele tipo de equipamento naquela amostragem.

Existem várias maneiras de se analisar a eficiência de equipamentos. O ciclo Carnot trata da análise do o ciclo ideal, ou seja, sem perdas. O trabalho em questão não trata do conceito utilizado no ciclo Carnot, porém, vislumbra a análise de uma máquina diante de mínimos e máximos dentro de determinada amostragem.

Segundo, Oliveira e Dechoum (2003, p. 359) “a máquina térmica ideal é a analisada no ciclo de Carnot por ser a máquina que maximiza os ganhos, ou seja, o trabalho que pode ser extraído sem alterar a entropia do universo".

Ao se operar no ciclo de Carnot, tem-se que, considerando um fluxo de energia, sem perda ou sem degradação, o mesmo caminho, independentemente do sentido do fluxo, pode ser refeito, sem perda ou sem degradação. “A máquina de Carnot tem um atributo a mais sobre qualquer outra máquina reversível por fixar um limite máximo à rentabilidade, 
quer dizer, há um limite máximo por ciclo para extração de trabalho sem comprometer a reversibilidade do processo, sem degradar energia útil”' (OLIVEIRA, DECHOUM, 2013).

Conforme Simões Moreira (2012, p. 46) "o ciclo de Carnot é uma teorização de um ciclo em que se poderia obter a máxima eficiência térmica (...) e está associado com qualquer máquina, equipamento ou propriedades do fluido de trabalho".

Ticianelli e Gonzalez (1989) apontam que existem limitações de eficiência impostas pelo ciclo de Carnot às máquinas térmicas.

Nesse sentido, o ciclo do Carnot traz um perfil puramente teórico, que na perspectiva do mundo real corresponde à necessidade de incremento do uso de tecnologia para diminuir perdas. Porém, mesmo assim, sempre há uma expectativa de perdas, pois é impossível se chegar ao $100 \%$ de aproveitamento da energia utilizada em máquinas térmicas.

Tendo em vista esse panorama, optou-se por trabalhar com outra escala de eficiência dentro de uma base metodológica, considerando os valores mínimos e máximos de eficiência como os valores apresentados dentro da amostragem analisada.

Adotou-se dentro de todos os valores de eficiência apresentados para um tipo de equipamento dentro da escala, o mínimo como "zero" e o máximo observado como " 1 ".

Uma vantagem que pode ser observada com base no uso dessa metodologia é o uso de dados reais, tanto os valores de mínimos, quanto de máximos, são informações coletadas seguindo determinada rotina operacional, a partir de registros específicos de sistema monitoramento para se extrair resultados de eficiência.

\subsection{Impacto da construção civil na vida útil de um projeto}

A construção não pode ser observada como um processo uniforme ou que possua atividades constantes. Diferentes tipos de projetos apresentam distintas características que podem influenciar em seu consumo energético, conforme a variabilidade dos insumos necessários e das singularidades de suas aplicações.

De acordo com estudo publicado pelo DIEESE (2012), existem três grandes segmentos na indústria da construção. O primeiro pode ser caracterizado como a construção de edifícios - formado pelas obras de edificações ou residenciais e por obras de 
incorporação de empreendimentos imobiliários. O segundo, e alvo deste trabalho, é o segmento formado pela construção pesada ou obras de infraestrutura. Já o terceiro, é o ramo de serviços especializados, conforme as divisões 41,42 e 43, da Classificação Nacional de Atividade Econômica, o CNAE 2.0 - IBGE.

Segundo a International Standard Industrial Classification of all Economic Activities - ISIC criada pela ONU, obras de grande porte compreendem a construção pesada, que abrange as obras de auto-estradas, ruas, pontes, túneis, ferrovias, aeroportos, portos e outros projetos de água, sistemas de irrigação, sistemas de esgotos, instalações industriais, gasodutos e linhas elétricas, instalações esportivas, entre outras. Em resumo, obras que integram complexos de infraestrutura. (ISIC, 2014).

Nos últimos anos, o Brasil observou um crescimento do setor da construção pesada devido ao aumento do volume de investimentos públicos e privados em obras de infraestrutura (DIEESE, 2012).

Das 50 maiores obras atuais de infraestrutura e energia do mundo, 14 estão no Brasil, com recursos que somam R $\$ 250$ bilhões (DIEESE, 2012).

Também, destaca-se que um mesmo tipo de projeto pode apresentar diferentes etapas construtivas. Segundo Monteiro Filha (2010), as principais etapas que podem ser destacadas possuem foco no planejamento, produção, uso e manutenção ou demolição.

$\mathrm{Na}$ etapa de planejamento é realizada a concepção do projeto. Aqui é o momento onde as necessidades do empreendedor e as do cliente são consideradas e ponderadas em relação às questões de sustentabilidade. Durante a etapa de planejamento, as principais decisões são tomadas visando atender a qualidade necessária do projeto, pois são determinados os aspectos de atendimento das exigências dos clientes, de adequação às questões técnicas, aos aspectos que envolvem sustentabilidade e as tecnologias aplicadas (MONTEIRO FILHA, et al, 2010).

A etapa de produção corresponde ao período efetivo de construção do empreendimento. Nesta etapa ocorrem os maiores impactos na região de onde será implantado o empreendimento em um menor espaço de tempo. Requer acompanhamento para que sejam detectadas as necessidades não previstas. Durante a construção, os principais insumos materiais e energéticos são incorporados ao empreendimento. Há também externalidades que são geradas, com a geração de esgotos, gases poluentes e de gases de efeito estufa, geração de resíduos e, por vezes, até alteração de ecossistemas (MONTEIRO FILHA, et al, 2010). 
$\mathrm{Na}$ etapa de uso, o empreendimento é entregue ao contratante juntamente aos documentos relacionados à construção, como planta, cortes e memoriais, além de um manual onde constam as informações técnicas necessárias, como limpeza, conservação, uso e manutenção do empreendimento. Esta etapa é a mais duradoura, onde o empreendimento servirá ao seu propósito de criação. Durante esta fase ocorrem grandes consumos energéticos, porém em menores intensidades e com maior temporalidade (MONTEIRO FILHA, et al, 2010).

Durante a manutenção ocorrem reformas e melhorias nas edificações. Já durante a demolição há o desmonte e a destruição da edificação. Nestas etapas há grande parte da geração dos resíduos sólidos da vida útil de uma edificação (MONTEIRO FILHA, et al, 2010).

Em termos energéticos, a construção civil consome uma parcela menor, porém significativa e intensiva, quando comparada ao ciclo de vida de uma edificação - em torno de $15 \%$ a $20 \%$ do total de energia (UNEP, 2007).

Todas estas etapas podem ser esquematizadas conforme a Figura 4. No presente trabalho, o foco é concentrado na etapa de produção, ou seja, durante a construção do empreendimento, onde ocorrem os mais intensos consumos energéticos da vida útil de um empreendimento.

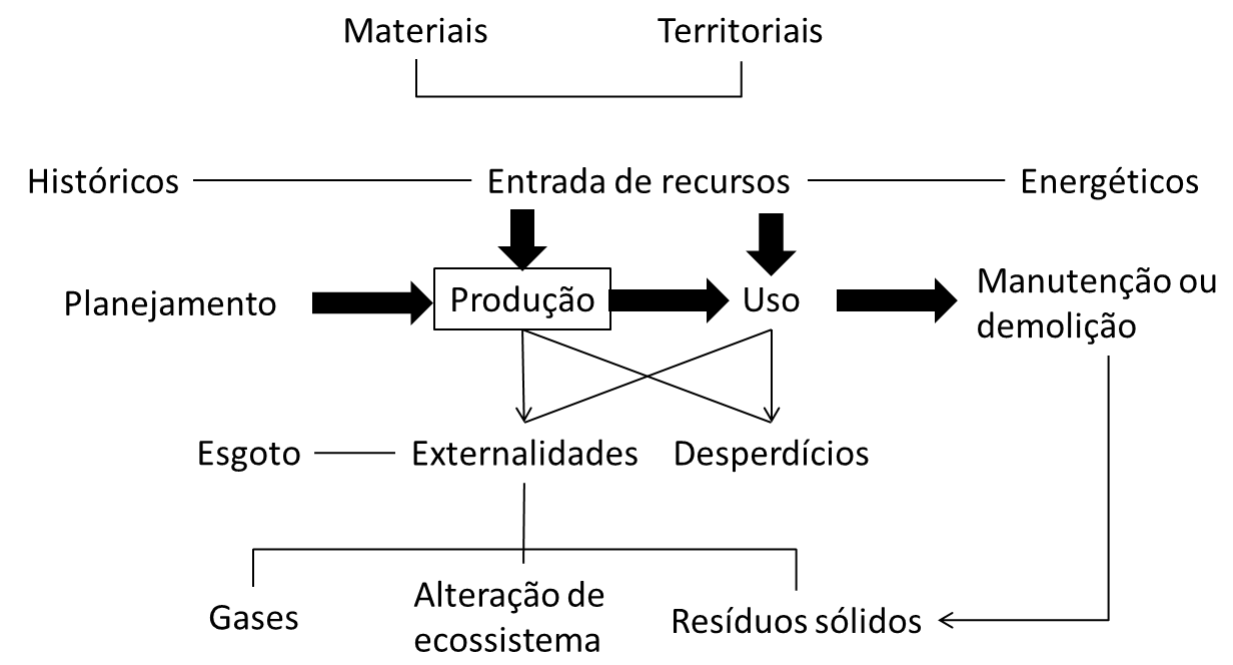

Figura 4 - Esquematização simplificada do Ciclo de Vida da Construção Civil.

Fonte: Monteiro Filha, et al 2010. 
No contexto da melhoria de eficiência no uso da energia, a indústria da construção civil requer uma atenção especial. Isto se deve, fundamentalmente, ao fato de se tratar de uma área energo-intensiva - ou seja, com alto consumo energético por unidade produzida e que utiliza diversos insumos também intensivos em energia.

Considerando a vida útil de uma edificação, o consumo energético do período de construção é inferior ao consumo energético de uma edificação concluída, porém, a intensidade com que este consumo ocorre mostra que a construção civil é de fato um item relevante para a questão de eficiência energética (SUZUKI, 1998 e JUNILLA, 2004).

$\mathrm{Na}$ Figura 5 é evidenciada a participação do consumo energético do período da construção dentro da análise do ciclo de vida de edificações japonesas (SUZUKI, 1998), americanas e finlandesas (JUNILLA, 2004). Estes dados servem como exemplo para iniciar o entendimento da participação energética da construção civil. É mais comum encontrarmos informações a respeito de obras de pequeno porte devido à sua homogeneidade. No entanto, no caso de obras de grande porte, há alta variabilidade de informações e de tipos de perfis na construção.

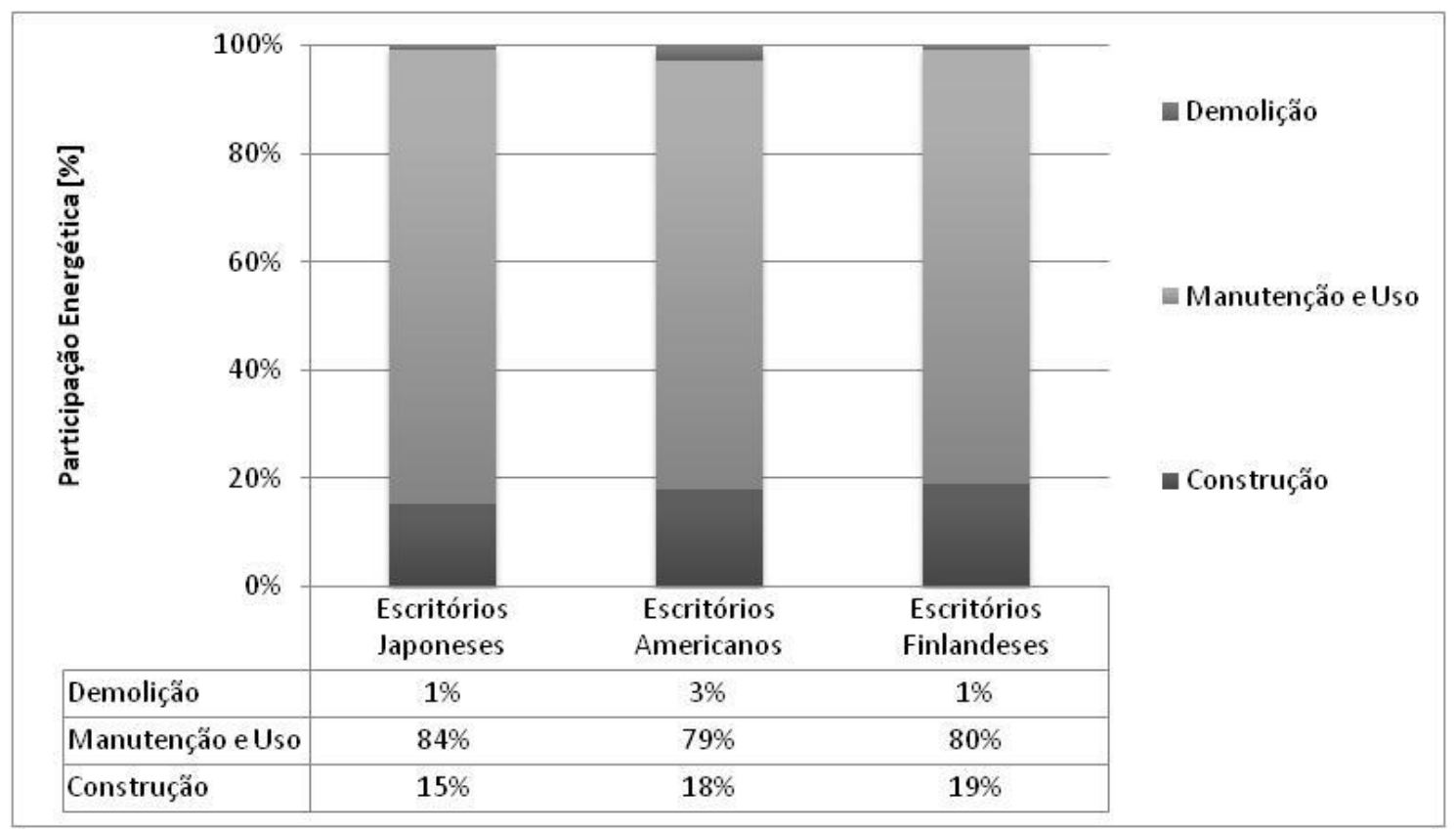

Figura 5 - Participação energética durante a vida útil de edificações.

Fonte: Adaptado de SUZUKI, 1998 e JUNILLA, 2004. 
Avaliando-se a revisão bibliografia efetuada, constatou-se apenas alguns estudos que citam genericamente o consumo energético no período de construção como foco (CURSINO, 2011) (SUZUKI, 1998) (JUNILLA, 2004).

Do ponto de vista energético, é de grande relevância identificar em qual etapa o processo construtivo se encontra. Para cada uma dos níveis da construção há perfis de atividades diferentes que podem ocorrer, caracterizando distintas intensidades energéticas (APUC, 2008).

Um processo construtivo apresenta três principais fases distintas conforme o nível de atividade apresentada (APUC, 2008). São elas a mobilização, o pico e a desmobilização, melhor visualizadas na Figura 6.

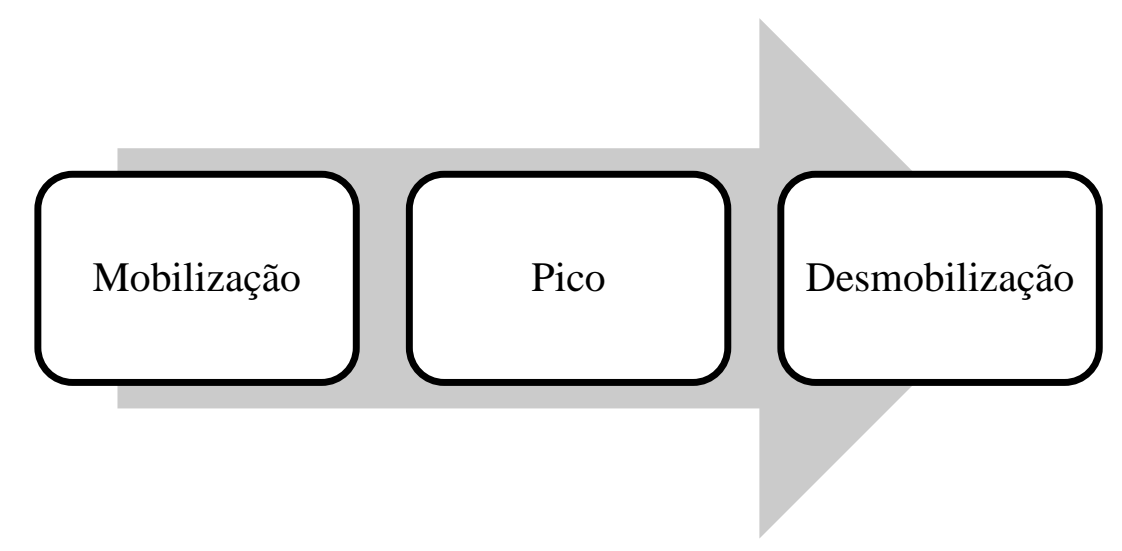

Figura 6 - Principais fases de um projeto de construção.

Fonte: Elaboração própria adaptado de APUC, 2008.

Durante a etapa de mobilização há a admissão das equipes que farão parte do projeto, aquisição dos equipamentos e início da operação. Nesta etapa há o estabelecimento do canteiro de obras de forma física com a organização do site, nomeação de equipes e preparo para as primeiras atividades (APUC, 2008).

O pico de um projeto é caracterizado pelo auge da produção, onde ocorre a maior movimentação de equipamentos e a execução do projeto. Nesta etapa há o maior consumo energético da fase de construção de um projeto (APUC, 2008).

Já a etapa de desmobilização é marcada pelo encerramento de grande parte das atividades construtivas, com a saída do efetivo contratado e redução considerável das 
atividades. Nesta etapa, ainda, realizam-se serviços, porém com foco em atividades de acabamento para garantir a entrega do produto final (APUC, 2008).

A comparação de forma isolada de consumo energético sem a devida análise da fase em que o projeto se encontra não traria reais conclusões, pois claramente em um projeto em fase de mobilização ou desmobilização haveria menor consumo energético do que em um projeto em seu pico. Assim, análises de grupos de obras, mesmo que em diferentes etapas, traria um resultado mais homogêneo, possibilitando maiores comparações.

O trabalho analisa dados de todas essas fases de uma obra, considerando os dados de um ano de operação. Vale ressaltar que utilizando dados de fases isoladas os resultados podem ser distintos, uma vez que ao se considerar a mobilização ou desmobilização, devido à natureza dessas fases, o consumo energético obtido seria menor.

\subsection{Problemática energética na etapa de construção}

Há um conjunto de segmentos industriais que respondem por importante parcela do consumo industrial de eletricidade. Esses segmentos industriais englobam na sua maioria materiais eletro-intensivos, podendo se dizer que todos eles são, sem exceção, também energo-intensivos. Os grandes consumidores industriais de eletricidade são a cadeia produtiva do alumínio, incluindo a produção de alumina e a extração de bauxita, siderurgia (produção de aço bruto), ferro ligas, pelotização, cobre, petroquímica (produção de polímeros), soda-cloro, papel e celulose, e cimento (MME, EPE, 2012).

A produção de insumos básicos de diversos setores da economia fica a crédito destes segmentos, desde a construção civil, incluindo obras de infraestrutura, à produção de utensílios de uso cotidiano, passando pela fabricação de máquinas e equipamentos, entre outras aplicações (MME, EPE, 2012).

No que diz respeito a alumínio e aço, a construção civil é responsável por 14\% do alumínio e 7,2\% do aço consumidos no Brasil (MME, EPE, 2012).

O cimento e aço são insumos energo-intensivos relevantes para a construção. Os mecanismos de gerenciamento que poderiam render uma maior redução da intensidade 
energética intrínseca ao consumo destes materiais são encargos da cimenteira e da siderúrgica responsáveis por sua fabricação (MME, EPE, 2012).

Nestes casos, a gestão na cadeia de fornecedores estaria sob gerenciamento da empresa construtora, tomando por critérios a logística de fornecimento e a energia utilizada para confecção propriamente dita. Pode-se observar, que esse tipo de gestão vem ocorrendo com o objetivo de redução de gases de efeito estufa (CDP, 2011).

Já no caso do combustível, outro insumo de importância energética dentro de obras de construção civil, a combustão ocorre sob influência direta da construtora. Neste caso, é possível uma gestão reforçada e mais eficiente por parte da empresa atuante na obra.

A partir dos dados publicados no Carbon Disclosure Project - CDP, foi feito o cálculo e se constatou que $97 \%$ do consumo energético direto de uma construtora provêm da queima de combustíveis fósseis, sendo apenas $3 \%$ do consumo energético proveniente de eletricidade (CDP, 2011).

De acordo com IBGE (2010), os custos destinados à aquisição de combustíveis na construção civil no Brasil podem variar de $6 \%$ a 20\%. Isso evidencia a importância de uma gestão equilibrada e eficaz deste insumo.

Para uma melhor gestão, é relevante o conhecimento dos equipamentos e maquinários que queimam tais combustíveis.

Neste sentido, Habert et al. (2012) traz uma lista de equipamentos mais comumente utilizados durante uma obra de construção civil na França: Escavadeira de esteiras; Caminhões para transporte de materiais; Geradores a diesel; Plantas de mistura de concreto; Caminhão agitador; e Caminhão bombeador de concreto (HABERT et al., 2012).

Em relação ao Brasil, observou-se a mesma tendência em termos de maquinário. Maciel e Castro (2009) citam os seguintes equipamentos: escavadeira, pá-carregadeira, mini-carregadeira, caminhão, bate estaca, perfuratriz, empilhadeira e grua. Nesse trabalho, também, foi feito o levantamento dos principais equipamentos utilizados a partir de dados da empresa escolhida para estudo de caso, conforme descritos no item 4.3 e no apêndice 6.1 . 


\subsection{Balanço de energia útil para análise da relevância energética dos insumos}

Avaliando-se os métodos e os sistemas de gestão energética é possível ponderar a escolha de medidas mais eficazes e, assim, justificar incrementos nos investimentos em eficiência energética (EPA, 2007). Partindo-se deste princípio, para analisar a distribuição energética ao longo da cadeia de construção se faz necessário utilizar um método que atenda às peculiaridades deste setor.

O Balanço de Energia Útil (BEU), elaborado pelo Ministério de Minas e Energia (MME, 2005), é um método que visa estabelecer a distribuição da energia útil e estimar o potencial de economia de energia para diferentes insumos energéticos em diferentes setores de usos finais de energia (MME, 2005).

O óleo diesel, gasolina, álcool, querosene, gás natural e GLP são alguns exemplos de insumos analisados pelo BEU. Já os setores da economia tratados pelo BEU são os setores energéticos, residencial, comercial, transporte, cimento, ferro-gusa, aço, entre outros.

A partir do processamento das informações setoriais, são obtidas estimativas da Energia Final ${ }^{1}$ destinada a sete diferentes Usos Finais.

O primeiro compreende o consumo energético para a geração de força motriz. A energia é usada em motores estacionários ou em motores de veículos de transporte individual ou coletivo, de carga, tratores, máquinas agrícolas, de terraplenagem e de movimentação de terras (MME, 2005).

O calor de processo trata da energia usada em caldeiras e aquecedores de água ou de fluidos térmicos para a geração de energia térmica (MME, 2005).

Há também o chamado aquecimento direto que foca a energia utilizada em fornos, fornalhas, radiação, aquecimento por indução, condução e micro-ondas (MME, 2005).

Outro uso final destacado pelo BEU é refrigeração, abrangendo a energia usada em geladeiras, freezers, equipamentos de refrigeração e ar condicionado, tanto de ciclo de compressão como de absorção (MME, 2005).

A energia usada em iluminação interna ou externa também é tratada como um uso final separado (MME, 2005).

\footnotetext{
${ }^{1}$ Cabe denotar que entende-se por energia final o total de energia fornecido, ou seja, a soma da parcela de energia útil e da energia perdida no processo (MME, 2005).
} 
Outra classificação tratada de forma específica no BEU é a eletroquímica, abrangendo a energia usada em células eletrolíticas, processos de galvanoplastia, eletroforese e eletrodeposição (MME, 2005).

Para outros usos finais, a exemplo da energia utilizada em computadores, telecomunicações, máquinas de escritório, xerografia e equipamentos eletrônicos de controle, o BEU apropria-se de uma classificação denominada "outros usos" (MME, 2005).

O Balanço de Energia Útil considera que a energia útil é dada pela (1).

$$
\mathrm{EU}=\mathrm{EF}-\mathrm{EP}
$$

Onde:

$$
\begin{array}{lll}
\text { EU } & =\text { Energia Útil } & {[\mathrm{J}]} \\
\mathrm{EF} & =\text { Energia Final } & {[\mathrm{J}]} \\
\mathrm{EP} & =\text { Energia Perdida } & {[\mathrm{J}]}
\end{array}
$$

Sendo ainda a parcela de energia perdida dada pela (2).

$$
\mathrm{EP}=\mathrm{ENR}+\mathrm{EPEc}
$$

Onde:

ENR = Energia não Recuperável

EPEc $=$ Energia com Potencial de Economia

O MME (2005) utilizou o modelo computacional Modelo para a Avaliação do Potencial de Economia de Energia (MAPEE) visando a ampliação da utilização do BEU e permitindo gerar a estimativa do potencial de economia de energia para os diferentes insumos energéticos aplicados aos diferentes usos finais de cada um dos setores analisados. O modelo toma por base rendimentos de referência para os processos considerados, comparativamente aos rendimentos atuais de eficiência energética (MME, 2005). 
Nesse trabalho, a preponderância da utilização do BEU como ferramenta conceitual ocorre, principalmente, no capítulo 3, que trata do método para construção dos parâmetros do indicador de eficiência calculado.

O BEU é utilizado para definir o uso final, o qual a energia está sendo destinada, com isso delineou-se a desagregação de equipamentos estudados frente aos usos finais. Para afunilar a análise, optou-se, também, na construção da classificação da destinação da energia por tipo de equipamento, conforme apresentado no capítulo 4.

\subsection{Análise do Retorno Sobre o Investimento de Energia}

O EROI - Retorno Sobre o Investimento de Energia (Energy Return On Investment) analisa a quantidade de energia que se recupera dentro de um processo para cada unidade energética. Analogicamente, é possível traçar um paralelo com a definição de Payback, onde este analisa o retorno de investimento financeiro sobre o fator temporal.

Dessa forma, entende-se por EROI a razão entre a quantidade de energia obtida por um processo de produção e a quantidade de energia (ou o seu equivalente de outra fonte) que é necessária para obtenção de uma nova unidade de energia.

De acordo com Murphy e Hall (2010), o EROI não deve ser confundido com a eficiência de conversão, como acontece muitas vezes na literatura, por exemplo, em relação ao refino de gasolina a partir de petróleo.

A partir dos resultados de EROI é possível determinar a viabilidade de um dado projeto, comparando-se qual a proporção de energia gerada com a energia utilizada. A ideia é compreender que quanto menor o EROI, menor será a quantidade de energia gerada em relação à quantidade de energia inserida no sistema.

Por exemplo, considerando a construção de uma hidrelétrica, onde a expectativa de geração é por toda sua vida útil após a construção, espera-se que o total de energia produzido durante todo o período, seja maior do que toda a energia que foi inserida durante o processo construtivo.

Segundo Gately, 2007, os custos energéticos podem ser divididos em quatro níveis cumulativos de abrangência. A Figura 7 ilustra esta classificação. 


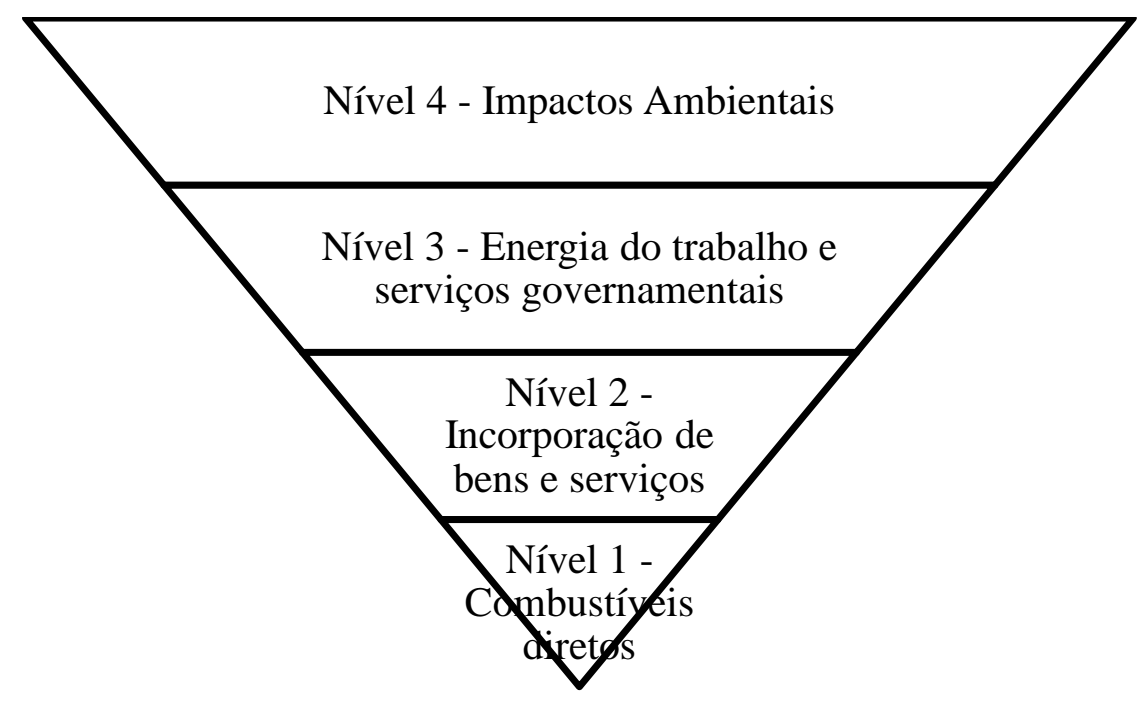

Figura 7 - Classificação da abrangência do EROI

Fonte: Elaboração própria baseado em GATELY, 2007

Segundo Gately (2007), o primeiro nível é o mais simples dos quatro, abrangendo somente a energia proveniente de queima de combustíveis utilizados diretamente pelo projeto. Os custos diretos são de responsabilidade da construção, sendo assim de obtenção simplificada.

Os custos energéticos indiretos são mais difíceis de identificar e avaliar, apesar de muitas vezes serem mais significativos e abrangentes do que os custos diretos. Os custos indiretos estão fracionados nos próximos três níveis de abrangência (GATELY, 2007)

O nível 2 abrange a soma do nível 1 à energia incorporada aos bens e serviços utilizados no processo. O terceiro nível abrange o segundo somado à energia dispendida no trabalho e serviços governamentais. Já o quarto nível corresponde ao nível 3 mais os serviços ecossistêmicos, entendidos como os custos energéticos de quaisquer danos advindos das depleções e poluições ambientais (GATELY, 2007).

A Tabela 2 demonstra a magnitude de diversos valores de EROI para vários recursos energéticos nos EUA, alguns deles com avanço no tempo, como o caso de óleo e gás. Demonstra também a relevância da hidrelétrica que apresenta um dos maiores retornos em termos de energia aplicada (MURPHY e HALL, 2010). 
Tabela 2 - Valores usuais de EROI para diversos recursos energéticos

\begin{tabular}{|c|c|c|}
\hline Recurso & Ano & EROI \\
\hline \multicolumn{3}{|l|}{ Combustíveis fósseis } \\
\hline Óleo e gás & 1930 & maior que 100 \\
\hline Óleo e gás & 1970 & 30 \\
\hline Óleo e gás & 2005 & 11 a 18 \\
\hline Descoberta & 1970 & 8 \\
\hline Produção & 1970 & 20 \\
\hline Produção mundial de óleo & 1999 & 35 \\
\hline Óleo importado & 1990 & 35 \\
\hline Óleo importado & 2005 & 18 \\
\hline Óleo importado & 2007 & 12 \\
\hline Gás natural & 2005 & 10 \\
\hline Carvão & 1950 & 80 \\
\hline Carvão & 2000 & 80 \\
\hline Areias betuminosas & & 2 a 4 \\
\hline Óleo de xisto & & 5 \\
\hline \multicolumn{3}{|c|}{ Outras energias não renováveis } \\
\hline Nuclear & & 5 a 15 \\
\hline \multicolumn{3}{|l|}{ Renováveis } \\
\hline Hidrelétricas & & maior que 100 \\
\hline Turbinas Eólicas & & 18 \\
\hline \multicolumn{3}{|l|}{ Coletores Solares } \\
\hline Painéis & & 1,9 \\
\hline Concentradores solares & & 1,6 \\
\hline Fotovoltaicas & & 6,8 \\
\hline \multicolumn{3}{|l|}{ Biomassa } \\
\hline Etanol de cana-de-açúcar & & 0,8 a 10 \\
\hline Etanol de milho & & 0,8 a 1,6 \\
\hline Biodiesel & & 1,3 \\
\hline
\end{tabular}

A um primeiro momento, optou-se neste trabalho por focar no nível 1 de análise do EROI, de forma a verificar a relevância dos combustíveis diretos na proporção de entrada de energia e saída durante a operação das hidrelétricas. Para tal é de grande importância a análise dos principais combustíveis utilizados em projetos de construção de grande porte, o que e melhor detalhado no capítulo 3. 


\subsection{Combustíveis}

Diversos tipos de combustíveis são encontrados em obras de construção civil. Os mais comuns são o diesel e a gasolina, porém outros em menores quantidades também podem ser observados.

O diesel é formado por hidrocarbonetos parafínicos com uma porção de naftênicos e aromáticos, com cadeias que variam de 10 a 25 átomos de carbono. Possui uma faixa de destilação entre 150 e $400^{\circ} \mathrm{C}$. Seu principal uso é em máquinas a combustão interna que operam em ciclo Diesel, como por exemplo, caminhões, tratores ou sistemas de geração de eletricidade (BRASIL et al, 2012).

Já a gasolina possui cadeias de 5 a 10 átomos de carbono, em uma faixa de ebulição entre 30 e $220^{\circ} \mathrm{C}$. Destaca-se o uso como combustível de motocicletas, veículos a ciclo Otto ou pequenas embarcações (BRASIL, et al, 2012).

O biodiesel é um óleo obtido através da reação de transesterificação de diversos insumos, em sua maior parte através de sementes de oleaginosas como soja, algodão, palma, amendoim, ou em alguns casos óleos de fritura ou sebo animal (NCAUR, 2005). Em 2012, o montante de biodiesel produzido no Brasil atingiu a marca de $2.717 .483 \mathrm{~m}^{3}$, um aumento de $1,7 \%$ em relação ao ano anterior. A principal matéria-prima foi o óleo de soja, com a participação de 69,6\%, seguido do sebo bovino, com 14,7\% (MME, 2013).

Quanto ao etanol, também consumido em veículos leves (quando hidratado) e em misturas com a gasolina comercializada em diversos países (etanol anidro), no Brasil houve um acréscimo em sua produção em 2012, correspondente a 2,4\% em comparação a 2011. Cerca de 59,3\% deste total referem-se ao etanol hidratado (MME, 2013).

Os dados de combustíveis analisados no presente trabalho são provenientes de uma gama de países que por vezes não utilizam a de mesma proporção biocombustíveis na mistura fornecida aos consumidores. Estas parcelas de biocombustíveis inseridos são definidas pelo governo de cada país onde o combustível será fornecido ao consumidor final. A nomenclatura utilizada toma por base a porcentagem de biocombustível na porção fóssil, por exemplo, Diesel BX refere-se a X\% de biodiesel na mistura, enquanto que Gasolina EY refere-se a Y\% de etanol na mistura.

No caso do Brasil a definição vem através de resoluções da ANP, que delimita a adição de $5 \%$ de biodiesel no diesel nacional comercializado, segundo a Resolução da Agência Nacional do Petróleo, Gás Natural e Biocombustíveis - ANP 07 de 19/03/2008 
(ANP, 2008) e a Lei 11.097 de 13/01/2005 (BRASIL, 2005). No caso da gasolina comercializada, demarca a adição de $25 \%$ de álcool etílico anidro combustível à gasolina tipo A, segundo a Resolução Conselho Interministerial do Açúcar e do Álcool - CIMA 37 de 27/06/2007 (CIMA, 2007) e a Resolução ANP 36, de 6/12/2005 (ANP, 2005).

Durante o ano de 2011 a gasolina sofreu uma alteração para E20 a partir de outubro do mesmo ano segundo a Portaria do Ministro de Estado da Agricultura, Pecuária e Abastecimento - MAPA 678, de 31/08/2011 (MAPA, 2005). Para as devidas conversões, considerou-se que a gasolina consumida durante o ano teria as médias de etanol apresentados no ano, ou seja, trabalhou-se com o valor de $23,75 \%$ de etanol na gasolina.

O presente trabalho conta também com informações de consumo de combustíveis em Angola, Argentina, Colômbia, Cuba, Estados Unidos, México, Moçambique, Panamá, Peru, Portugal, República Dominicana e Venezuela.

Para uma análise energética mais eficaz é importante conhecer a participação de biocombustíveis nos insumos energéticos para assim analisar seu potencial em termos de energia. Segundo IEA (2011) países como Angola, Cuba, Estados Unidos, Moçambique, Panamá, Portugal, República Dominicana e Venezuela utilizavam diesel e gasolina sem misturas com biocombustíveis em sua matriz no ano de 2011, ano em que os dados foram coletados.

Já no caso da Argentina, o diesel distribuído possuía uma parcela de $7 \%$ de biodiesel e a gasolina 5\% de etanol em sua composição. A Colômbia possuía 10\% de biodiesel e $10 \%$ de etanol em suas composições de gasolina e diesel, respectivamente. O Peru aprestava $2 \%$ de biodiesel e 7,8\% de etanol em seus insumos. O México possuía uma parcela de $2 \%$ de etanol em sua gasolina e diesel puro (IEA, 2011).

Essas parcelas de biocombustíveis na matriz de cada país evoluíram com o passar dos anos. Para o ano de 2014 muitos já apresentam porções maiores de biocombustíveis em sua matriz, evidenciando a relevância dos combustíveis renováveis nos dias atuais (Biofuels Digest, 2014), porém, como os dados que serviram de base para o presente trabalho são do ano de 2011, optou-se por utilizar as proporções de biocombustíveis utilizadas neste mesmo ano para cada país. 


\subsection{Análise de incertezas}

Dentro das mais diversas fontes de amostragem de informações, é importante observar que há incertezas associadas aos dados gerados. A análise destas incertezas demonstra a relevância de determinada informação dentro da apreciação do conjunto de informações coletadas (IPIECA, 2009).

Conforme estudo do IPCC (2006), diversos são os fatores que podem levar às incertezas no processo de coleta de informações, os quais também podem ser vislumbrados no presente trabalho.

Dentre tais fatores, merece destaque a falta de integralidade das informações coletadas, caracterizada pela ausência de certos dados, assim como pela falta de reconhecimento do processo de coleta ou pela ausência de método de medição específico e necessário para verificar a acurácia dos dados.

Também, pode-se referenciar a adoção de determinados modelos que não retratam a realidade com exatidão e que, consequentemente, aumentam o grau de incertezas do contexto resultante de sua respectiva análise.

Igualmente, o Fórum Clima (2013) aponta o efeito de incremento do grau de incertezas quando o sistema a ser estudado apresenta uma ausência de dados de determinada fonte considerada relevante ao processo analisado.

Outro fator que compromete a exatidão de análise dos resultados também é a falta de representatividade dos dados, que ocorre quando não há relação precisa entre os dados disponíveis e os resultados obtidos a partir dos modelos descritos.

Ademais, erros de medição podem ocorrer quando há equívocos nas informações medidas ou na aquisição de valores inexatos de constantes e de outros parâmetros obtidos a partir de fontes externas.

Erros durante o reporte ou a classificação ocorrem, principalmente, em virtude da falta de clareza ou de definição completa durante o final do relatório.

Também, realça-se que existe uma ligação entre o grau de incerteza durante o processo de aquisição de dados e o tipo de sistema de quantificação utilizado. Nesse sentido, para a forma manual de entrada de dados, pode-se mencionar como fator relevante o erro humano. Se forem utilizados os dados impressos, registros extraviados podem contribuir para aumentar o nível de incerteza. Para aquisição de dados instrumentais, a 
incerteza pode surgir a partir do sinal dos sensores e dispositivos utilizados (IPIECA, 2009).

Técnicas de controle de qualidade e práticas robustas de gerenciamento de dados podem minimizar os efeitos de muitas dessas fontes de incertezas. Por exemplo, uma checagem com base na comparação entre os valores de entrada conhecidos e seus resultados medidos ou calculados pode fornecer uma estimativa da incerteza de aquisição de dados (IPIECA, 2009).

Outro fator de incerteza relevante é a inexatidão de processamento dos dados decorrentes do processo de calibração. Este processo ocorre durante a calibração de um equipamento utilizando dados base, onde representam o melhor ajuste e dispersão das informações. No caso de ocorrer algum problema durante esta etapa de calibração, este erro pode ser dispersado para futuras análises (IPIECA, 2009).

Quanto melhor a qualidade do dado, menor será a incerteza associada e, portanto, espera-se que no aprimoramento da coleta de dados, quando possível, devem-se priorizar dados mensurados, calculados e estimados, respectivamente. Dados mensurados referemse aos valores medidos, calculados são os dados derivados de cálculo, e, por fim, estimados, referem-se aos valores fornecidos através do julgamento de um profissional (FÓRUM CLIMA, 2013).

Diante desse quadro, o presente trabalho traz no capítulo 3 o método de coleta e de utilização dos dados coletados, os quais baseiam a análise e o estudo da eficiência de equipamentos usualmente empregados por empresas do setor de construção de civil de grande porte.

Nessa perspectiva, a revisão bibliográfica aqui empreendida serve, sobretudo, como instrumento para a compreensão da acurácia de informações e de dados resultantes do monitoramento realizado pela empresa do estudo de caso, assim como do entendimento das consequências de adoção de determinados métodos, modelos, cálculos e técnicas de mensuração dos resultados.

\subsection{Considerações finais do capítulo}

Conforme visto, a literatura direcionou algumas premissas para a análise dos dados e discussão dos resultados, porquanto, um dos maiores consumos energéticos diretos da construção de grande porte ocorre pela queima de diesel em seus equipamentos. 
A literatura, também, apontou a importância da análise do consumo energético da etapa de construção civil, que é reconhecida como uma fase rápida e intensa da atividade do setor em questão.

Igualmente, pode-se verificar a partir da pesquisa bibliográfica os principais equipamentos utilizados na etapa estudada.

O EROI também trouxe o fato de que a hidrelétrica possui um dos maiores retornos por unidade de energia investida, direcionando a analise desse indicador para as hidrelétricas. 


\section{Método}

\subsection{Introdução}

O trabalho tem por base o levantamento de dados sobre o consumo energético de cada equipamento, assim como dados de eletricidade disponibilizada pela rede para consumo no canteiro.

Como já abordado anteriormente, o escopo do presente trabalho abrange a construção civil de grande porte. O estudo não tratou da Análise de Ciclo de Vida - ACV da edificação.

Foram analisados somente insumos energo-intensivos que são diretamente controlados pela construtora, ou seja, onde possui a gestão energética deste insumo. Insumos como cimento, aço, alumínio, não foram considerados, pois a energia embutida nestes materiais é controlada pelos fornecedores durante a fabricação do respectivo material.

Pelo exposto, esse capítulo encontra-se dividido nos seguintes itens: (i) banco de dados; (ii) dados utilizados no cálculo; (iii) métodos de coleta informação; (iv) análise energética; (v) utilização do balanço de energia útil (BEU) para verificação da relevância energética de diversos insumos na construção civil de grande porte; (vi) construção de parâmetros para classificação; e (vii) análise de incertezas.

\subsection{Banco de dados}

Inicialmente, compilou-se o banco de dados com informações acerca do consumo anual de combustíveis destinado ao manejo de 26.121 equipamentos em operação, em 84 obras de construção de grande porte, a fim da realização da análise energética, conforme definidos nos objetivos específicos descritos no Capítulo 1.

Os dados foram obtidos a partir da cessão de informações provenientes de empresa do setor de construção civil de grande porte, aqui denominada "Empresa X". O período de análise compreendeu os meses de janeiro a dezembro do ano de 2011.

A partir de 2012, o método de coleta de dados da Empresa $X$ foi alterado com a uniformização dos inventários de gases de efeito estufa da construção civil de grande porte. 
$\mathrm{O}$ ano de 211 corresponde ao ano zero em que a Empresa $\mathrm{X}$ realizou uma coleta de dados de consumo para o relato de suas emissões de gases de efeito estufa, obtendo informações por segmento do destino de todo combustível consumido internamente.

Primeiramente, a partir dos dados coletados, procedeu-se à classificação das obras da "Empresa X" por tipo, excluindo os equipamentos exclusivamente utilizados em escritórios, tais como alguns automóveis de pequeno porte, buscando-se considerar somente os equipamentos que são utilizados em obras de construção civil de grande porte em si, mesmo que aqui apresentem algumas unidades de veículos de pequeno porte. A Tabela 3 traz os quantitativos dessas obras no período em análise. 
Tabela 3 - Quantitativos de obras da "Empresa X" no período entre janeiro e dezembro de 2011.

\begin{tabular}{|c|c|}
\hline Tipo de Obra & Quantidades \\
\hline Adutora & 2 \\
\hline Aeroporto & 2 \\
\hline Barragem & 1 \\
\hline Concessionária & 3 \\
\hline Concessionária Rodovia & 1 \\
\hline Dragagem & 1 \\
\hline Drenagem & 1 \\
\hline Edificação & 7 \\
\hline Estaleiro & 1 \\
\hline Ferrovia & 2 \\
\hline Gasoduto & 1 \\
\hline Hidrelétrica & 8 \\
\hline Irrigação & 1 \\
\hline Metrô & 4 \\
\hline Montagem & 5 \\
\hline Pavimentação & 1 \\
\hline Pedreira & 1 \\
\hline Petroquímica & 4 \\
\hline Plataforma & 1 \\
\hline Ponte & 1 \\
\hline Portuária & 3 \\
\hline Rede Elétrica & 2 \\
\hline Refinaria & 3 \\
\hline Rodovia & 11 \\
\hline Saneamento & 7 \\
\hline Siderúrgica & 1 \\
\hline Terraplanagem & 2 \\
\hline Túnel & 4 \\
\hline Urbanização & 2 \\
\hline Viaduto & 1 \\
\hline
\end{tabular}

Fonte: Empresa X (2011).

\subsection{Dados utilizados nos cálculos}

Foram separados os equipamentos, objeto da análise, e em seguida, foram examinados os diferentes combustíveis, colocando-as na mesma base energética. A Tabela 4 traz os dados de poder calorífico e de densidade utilizados para conversão em giga Joule (GJ), assim como as informações de litros de combustíveis para uniformização do acervo de dados. Tendo em vista que biocombustíveis e combustíveis fósseis apresentam poder 
calorífico e densidade distintos, a presente tabela faz a distinção entre combustíveis renováveis e não renováveis, apresentando o resultado da mistura em suas últimas colunas.

Tabela 4 - Uniformização dos dados por base energéticas

\begin{tabular}{|c|c|c|c|c|c|c|}
\hline Combustível & $\begin{array}{c}\text { Poder } \\
\text { calorífico não } \\
\text { renovável } \\
{[\mathrm{kcal} / \mathrm{kg}]}\end{array}$ & $\begin{array}{c}\text { Densidade da } \\
\text { Porção não } \\
\text { renovável } \\
{[\mathrm{kg} / \mathrm{l}]}\end{array}$ & $\begin{array}{c}\text { Poder } \\
\text { calorífico da } \\
\text { Porção } \\
\text { renovável } \\
{[\mathrm{kcal} / \mathrm{kg}]}\end{array}$ & $\begin{array}{c}\text { Densidade da } \\
\text { Porção } \\
\text { renovável } \\
{[\mathrm{kg} / \mathrm{l}]}\end{array}$ & $\begin{array}{c}\text { Poder } \\
\text { calorífico da } \\
\text { mistura } \\
{[\mathrm{kcal} / \mathrm{kg}]}\end{array}$ & $\begin{array}{c}\text { Densidade da } \\
\text { mistura } \\
{[\mathrm{kg} / \mathrm{l}]}\end{array}$ \\
\hline Diesel & 10.750 & 0,840 & 9.345 & 0,880 & 10.750 & 0,8400 \\
\hline $\operatorname{Diesel}^{2}$ (B20) & 10.750 & 0,840 & 9.345 & 0,880 & 10.469 & 0,8480 \\
\hline Diesel (B5) & 10.750 & 0,840 & 9.345 & 0,880 & 10.680 & 0,8420 \\
\hline Diesel (B7) & 10.750 & 0,840 & 9.345 & 0,880 & 10.652 & 0,8428 \\
\hline Diesel (B10) & 10.750 & 0,840 & 9.345 & 0,880 & 10.610 & 0,8440 \\
\hline Diesel (B2) & 10.750 & 0,840 & 9.345 & 0,880 & 10.722 & 0,8408 \\
\hline Etanol (E100) & 11.220 & 0,742 & 6.650 & 0,809 & 6.650 & 0,8090 \\
\hline Gasolina & 11.220 & 0,742 & 7.090 & 0,791 & 11.220 & 0,7420 \\
\hline Gasolina (E10) & 11.220 & 0,742 & 7.090 & 0,791 & 10.807 & 0,7469 \\
\hline Gasolina (E2) & 11.220 & 0,742 & 7.090 & 0,791 & 11.137 & 0,7430 \\
\hline Gasolina $(E 23,75)$ & 11.220 & 0,742 & 7.090 & 0,791 & 10.239 & 0,7536 \\
\hline Gasolina (E5) & 11.220 & 0,742 & 7.090 & 0,791 & 11.014 & 0,7445 \\
\hline Gasolina (E7.8) & 11.220 & 0,742 & 7.090 & 0,791 & 10.898 & 0,7458 \\
\hline
\end{tabular}

Fonte: GHG PROTOCOL BRASIL, 2012; BEN 2013; NREL, 2009.

Vale ressaltar que o fator de conversão utilizado de quilowatts hora (KWh) para gigajoule (GJ) foi 0,0036 .

Os dados de referência utilizados para o PCI de combustíveis são os referenciados no BEN 2010, cujo conteúdo pode ser localizado na Tabela VIII.9 (Densidades e Poderes Caloríficos Inferiores - 2009), exceto o biodiesel, que utiliza o PCI apresentado no documento Biodiesel Handling and Use Guidelines, US Department of Energy, 2004.

\subsection{Métodos de coleta da Informação}

Para análise energética restrita à eficiência, utilizaram-se somente informações obtidas a partir dos equipamentos monitorados via satélite.

As informações via satélite são processadas automaticamente e podem ser ligadas diretamente ao tempo em funcionamento para gerar estimativas de eficiência.

\footnotetext{
${ }^{2}$ Conforme explicado no capítulo da revisão bibliográfica, o termo BX se refere a X\% de combustível renovável adicionado ao diesel.
} 
Ainda, o método de monitoramento apresenta os seguintes benefícios: controle da frota durante a jornada de trabalho e monitoramento das operações efetuadas; gerenciamento do desempenho do equipamento e do operador; e otimização das operações e redução de custos (VOLKSNET, 2014).

Já os dados de faturamento e dados obtidos nas bombas de combustíveis sofrem transferências manuais para tabelas de cálculos a fim de serem consolidados. Podem apresentar erros de digitação ou de desatenção do operador que realizou as anotações ou do responsável para a transferência para o meio digital.

A partir das observações iniciais do banco de dados em questão, os insumos energéticos analisados no presente trabalho foram: óleo diesel, biodiesel adicionado ao óleo diesel, gasolina, etanol hidratado e anidro adicionado à gasolina e, finalmente, a eletricidade.

Todos os dados de eletricidade foram obtidos a partir das faturas de cada medidor que as obras apresentam. Estes dados foram transferidos manualmente para a forma digital.

Os dados originais consolidados de consumo por tipo de equipamento estão apresentados no apêndice 6.1. Os tipos de equipamentos apresentados são caminhão, escavadeira, gerador, trator de esteira, pá carregadeira, automóvel, compressor, draga, moto niveladora, pick up, retro escavadeira, rolo compactador, guindaste, ônibus, carreta perfuração e outros equipamentos. A categoria "outros equipamentos" referem-se aos equipamentos que possuem menor representatividade no consumo de combustíveis e, por sua vez, no consumo energético, como por exemplo, fresadora ou guincho.

As informações referentes a caminhões encontram-se desagregados no apêndice 6.2. Os tipos apresentados são caminhão basculante, caminhão comboio, caminhão tanque, caminhão guindaste, caminhão betoneira, caminhão pipa, caminhão articulado, caminhonete, caminhão plataforma, caminhão de reboque, caminhão baú, caminhão bomba, caminhão cavalo mecânico, caminhão de lixo, caminhão lança concreto, caminhão limpa fossa e caminhão munck.

\subsection{Análise energética}

A análise energética aqui realizada objetiva transformar todas as informações contidas no apêndice 6.1, convertendo-as para uma unidade energética única e a partir 
desse ponto avaliar o impacto de cada insumo energético na construção civil de grande porte.

Primeiramente, utiliza-se a (3) para determinar qual a massa de combustível que estaria sendo consumida.

$$
\text { Massa }=\text { Consumo } \cdot \delta
$$

Onde:
Massa Massa de combustível
$[\mathrm{kg}]$
Consumo Consumo do combustível
[1]
$\delta \quad$ Densidade relativa do combustível em questão
$\left[\mathrm{kg} . \mathrm{l}^{-1}\right]$

Em seguida, a (4) foi usada para transformar a quantidade de combustível em quilos para unidades energéticas.

$$
\text { Consumo energético }=\text { Massa } \cdot P C I \cdot \text { Fator de Conversão }
$$

Onde:
Consumo energético
Total de combustível utilizado convertido para [kcal] unidades energéticas
PCI
PCI do combustível em questão
$\left[\mathrm{kcal} . \mathrm{kg}^{-1}\right]$
Fator de Conversão
Fator de conversão entre kcal e GJ
$4,1910^{-6}$

Finalmente, para trazer todos os dados para uma base energética comum, os dados de energia elétrica consumidos, que apresentam como unidade o $\mathrm{KWh}$, foram convertidos para GJ utilizando-se o fator de 0,0036

Utilizando-se das informações da Tabela 4, no item 3.3, e considerando-se as devidas proporções entre biocombustíveis e combustíveis fósseis, pode-se analisar os combustíveis tendo por base a energia contida em cada um deles. 


\subsection{Utilização do balanço de energia útil (BEU)}

As aplicações do método estabelecidas pelo BEU para o presente estudo se deram de forma a estimar a quantidade de energia final, os coeficientes de destinação, e a distribuição da energia final para as obras de construção civil de grande porte.

Para a desagregação ser mais efetiva no que se relaciona aos diferentes usos finais em uma obra, e considerando o perfil de equipamentos das obras, optou-se por separar os usos finais, realizando-se assim uma adaptação dos conceitos do BEU, conforme apresentados na Tabela 5.

Tabela 5 - Método de desagregação de equipamentos utilizados neste estudo frente aos usos finais estabelecidos pelo BEU

\begin{tabular}{|c|c|}
\hline Uso Final & Equipamentos \\
\hline Força Motriz & \\
\hline $\begin{array}{l}\text { Equipamentos que } \\
\text { convertem energia de } \\
\text { combustíveis em força } \\
\text { motriz. }\end{array}$ & $\begin{array}{l}\text { Caminhão; Escavadeira; Trator de esteira; Pá carregadeira; Carreta de perfuração; } \\
\text { Motoniveladora; Rebocador; Retro escavadeira; Rolo compactador; Automóvel; Draga; } \\
\text { Compressor; Guindaste; Bomba }\end{array}$ \\
\hline Calor de Processo & Não identificados na base de dados fornecidos. \\
\hline Aquecimento Direto & Não identificados na base de dados fornecidos. \\
\hline Refrigeração & Não identificados na base de dados fornecidos. \\
\hline Iluminação & $\begin{array}{l}\text { Torres de iluminação: Equipamentos que convertem energia de combustíveis em uso } \\
\text { final iluminação. }\end{array}$ \\
\hline Eletroquímica & Não identificados na base de dados fornecidos. \\
\hline Outros & $\begin{array}{l}\text { Geradores: Equipamentos que convertem energia de combustíveis em uso final } \\
\text { eletricidade. }\end{array}$ \\
\hline
\end{tabular}

A maior parte dos equipamentos analisados e listados na Tabela 5 são utilizados para geração de força motriz, as exceções são torres de iluminação que convertem a energia de combustíveis para o uso final de iluminação, assim como os geradores, os quais convertem a energia química do combustível em eletricidade. Na Tabela 5 a eletricidade 
gerada por estes geradores não está contemplada como um uso final específico evitando-se a dupla contagem, posto que a energia proveniente da combustão do diesel nos gerados já foi contabilizada, por tal motivo esse uso final foi considerado na coluna "outros".

\subsection{Construção de parâmetros para classificação de indicador de eficiência}

O objetivo do item em questão é verificar como a eficiência de um conjunto de equipamentos utilizados em obras de construção civil de grande porte se comporta frente aos equipamentos mais e menos eficientes dentro deste mesmo conjunto, de forma a se comparar equipamentos operando em projetos reais sob cargas de trabalho reais.

Para isso, partiu-se de uma base de dados de eficiência energética e de atuação de 1.018 equipamentos que apresentavam tais informações obtidas através de monitoramento via satélite em quantidade de litros de combustíveis consumidos por hora trabalhada. Geraram-se as tabelas existentes no apêndice 6.10, utilizando por base alguns conceitos do BEU, já discutidos no item 2.6.

Com base no tipo de equipamento reportado, foi possível realizar 27 classificações de equipamentos, e uma categoria denominada "outros", para agrupar os equipamentos de menor representatividade.

As classificações foram as seguintes: bomba, caminhão, carregadeira de pneus, carreta de perfuração, cavalo mecânico, compactador, compressor, draga, empilhadeira, escavadeira, gerador, guindaste, manipulador telescópico, máquina de solda, mini carregadeira, mini escavadeira, misturador de concreto, moto niveladora, ônibus, perfuratriz, plataforma elevatória, plataforma telescópica, rebocador, retro escavadeira, torre de iluminação, trator, trator de esteira e outros.

A partir desta classificação gerou-se a Tabela 8 com valores médios de eficiência, máximos e mínimos. Os dados de menor consumo por hora trabalhada serão os ideais a serem observados, ou seja, os valores tomados como referência para melhor eficiência obtida em campo, já que todos os dados utilizados são dados reais, de equipamentos que estavam durante todo o período analisado em atividades em obras distintas.

Tendo estes valores mínimos como ideais de eficiência a serem obtidos, criou-se uma escala que pudesse ser transformada em unidades de porcentagem para comparação de eficiência alcançada no conjunto dos equipamentos. 
Buscou-se, assim, uma variação onde o valor mínimo, em termos de consumo energético, representasse o $100 \%$, desempenhando o melhor caso de eficiência observada. Nesta mesma escala o maior consumo de combustíveis por horas trabalhadas representaria o valor de $0 \%$, ou seja, a eficiência mínima.

Considerando esta escala, a mediana entre os valores de eficiência apresentados pelos equipamentos através deste indicador representaria uma porcentagem entre $0 \%$ e $100 \%$, em que, no caso de próxima à 100\%, a classe do equipamento apresentaria a maior parte da energia dispensada convertida em energia útil, e quanto mais próxima de $0 \%$, maior a atenção dispensada para que sua eficiência melhore e seu consumo diminua em função das horas trabalhadas. Em resumo, os valores que mais se aproximarem de $0 \%$ representam os equipamentos menos eficientes.

Optou-se por utilizar valores medianos com a finalidade de que os efeitos de valores extremos fossem amenizados (IPCC, 2012).

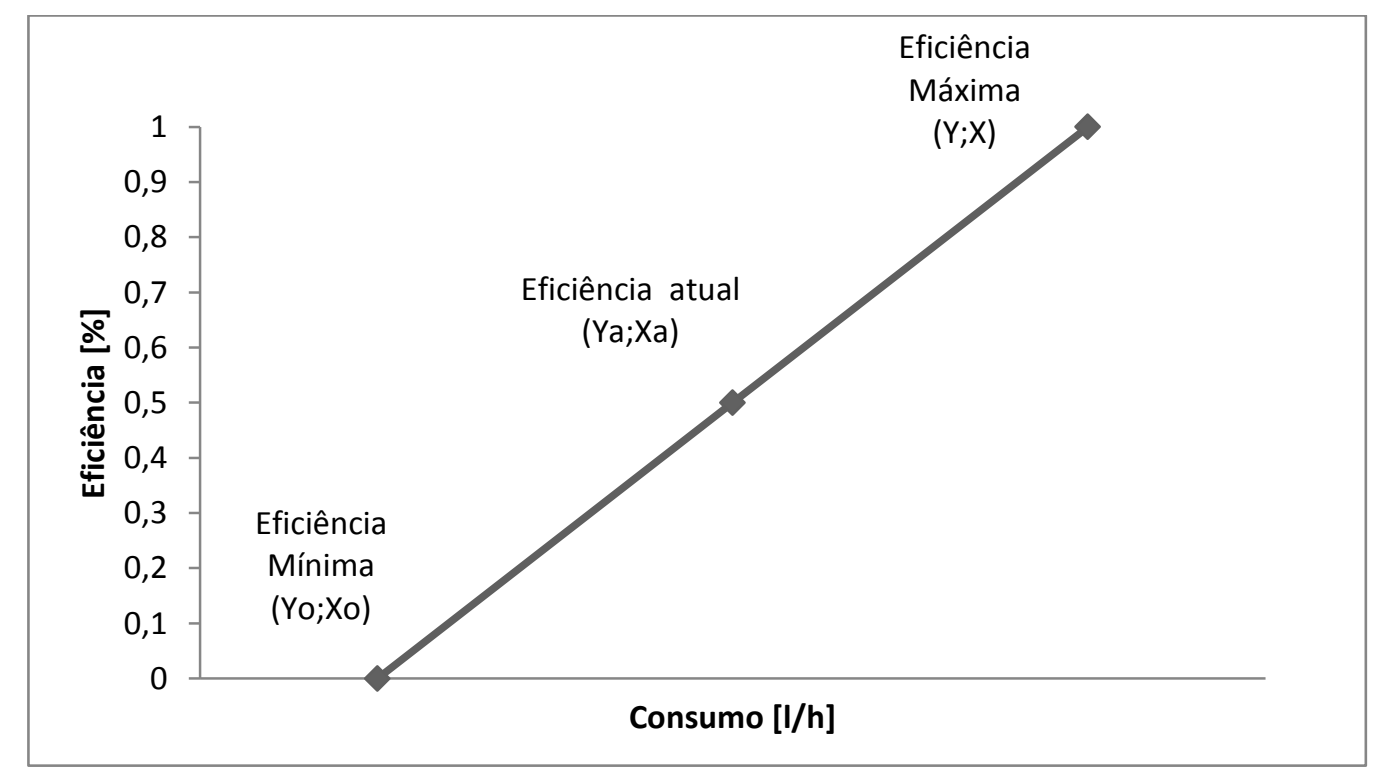

Figura 8 - Metodologia de classificação da o indicador de eficiência

Fonte: Elaboração própria

Para obtenção desta escala utilizou-se uma metodologia de crescimento linear, que foi obtido pela Equação (5).

$$
Y_{a}=\left(\left(X_{a}-X_{0}\right) \cdot\left(\frac{Y-Y_{0}}{X-X_{0}}\right)\right)+Y_{0}
$$


Onde:

Ya Valor em porcentagem que representa a eficiência atual [\%]

Y Valor em porcentagem que representa a eficiência máxima [\%]

Y0 Valor em porcentagem que representa a eficiência mínima [\%]

$\mathrm{X} \quad$ Taxa de consumo em litros por hora que representa a eficiência $\left[1 . \mathrm{h}^{-1}\right]$ máxima

X0 Taxa de consumo em litros por hora que representa a eficiência $\left[1 . h^{-1}\right]$ mínima

Xa Taxa de consumo em litros por hora que representa a eficiência atual $\quad\left[1 . h^{-1}\right]$

A destinação de energia de cada equipamento estudado foi adaptada do BEU e foi criada dentro dos parâmetros de uso final desse instrumento de análise energética. A partir da apropriação desses dados, estimou-se o percentual de energia destinada a cada uso final.

Em relação ao potencial de economia de energia nos diferentes usos, tomou-se por base o resultado da classificação de eficiência, fundamentando-se no fato de que na prática todos os equipamentos tem o potencial de eficiência de $100 \%$, considerando a classificação explicada acima e vislumbrada na Figura 8.

Logo, o potencial de economia é a diferença do percentual de eficiência apresentada por cada equipamento e o $100 \%$ de eficiência aqui construído.

\subsection{Análise de incertezas}

Para a explicação do grau de incerteza apresentado nesse trabalho, a Tabela 6 traz os parâmetros de incerteza recomendados para a análise de dados utilizados em inventário de gases de efeito estufa na construção civil de grande porte. A mesma sistemática será utilizada no presente trabalho a fim de verificar a relevância das informações colhidas. 
Tabela 6- Parâmetros para análise de incerteza para o consumo de combustíveis

\begin{tabular}{|clr|}
\hline & Medição direta com equipamentos específicos & $0,2 \%$ \\
\multirow{2}{*}{ Coleta de dados } & Medição direta com equipamentos genéricos & $0,5 \%$ \\
& Por documento de terceiros & $0,8 \%$ \\
& Por estimativa & $3,0 \%$ \\
\hline \multirow{2}{*}{ Lançamento no sistema } & Automático & $0,2 \%$ \\
& Manual & $1,5 \%$ \\
\hline \multirow{2}{*}{ Conversão } & Não há necessidade de conversão & $0,2 \%$ \\
& Conversão dimensional & $0,4 \%$ \\
& Conversão para outra unidade & $1,5 \%$ \\
\hline
\end{tabular}

Fonte: FÓRUM CLIMA (2013).

Considerando a Tabela 6 , realizou-se a verificação da incerteza baseada em três métodos de coleta de dados, método de lançamento dos dados no sistema, e se houve a necessidade de conversão de unidades durante o processo de coleta.

Quanto à coleta, todas as informações lançadas tem como fonte a medição direta de equipamento específico. Ela é coletada diretamente no equipamento analisado, não sendo proveniente de terceiros, estimativas ou médias genéricas, que ocasionam dados aproximados.

No tocante ao tipo de lançamento, reforça-se que parte é automático, principalmente, o monitoramento via satélite, e que a outra parte é manual, quando por exemplo, tem-se a coleta direta na bomba de combustível.

Em relação aos fatores de conversão, destaca-se que não existiu a necessidade da realização dessa operação, porque os valores obtidos já tinham sido gerados em litros.

\subsection{Utilização de EROI na análise de hidrelétricas}

A análise de EROI mostra-se relevante para a determinação do potencial de produção energética de um dado projeto. A presente análise igualmente mostra-se importante para demonstrar a proporção entre a energia de entrada em um projeto e a energia de saída, principalmente durante a análise de obras que, durante seu uso, gerarão energia, como o caso de hidrelétricas, usinas térmicas, usinas de fabricação de combustíveis ou usinas nucleares, por exemplo. No presente trabalho, observou-se esta relação em projetos de hidrelétricas tendo por base a análise do "nível 1", conforme a 
Figura 7, utilizando os dados de consumo de combustíveis diretos durante o processo de fabricação do conjunto de hidrelétricas inserido na base de dados utilizada.

Dentre a listagem de obras com informações de consumo de combustíveis, observou-se a presença de seis hidrelétricas com informações de capacidade instalada e período de operação. A partir destas informações é possível definir qual será a energia total produzida durante sua vida útil.

Para cada uma destas usinas, sabe-se quanto e qual tipo de combustível e quantitativo de eletricidade foram utilizados no ano de 2011. Com estas informações foi possível estimar quanto de combustível foi utilizado em 2011 no processo construtivo e sua respectiva conversão para unidades energéticas, a título de comparação com o total de energia produzida pela usina durante sua operação. Considerou-se uma média de 5 anos interruptos de construção para cada hidrelétrica.

A partir destes dados, é possível aplicar o EROI apresentado no item 2.7. O resultado desta operação é um número adimensional que representa quantas unidades energéticas serão produzidas a partir de uma unidade energética dispendida.

\subsection{Considerações finais do capítulo}

Como foi visto ao longo desse capítulo, a metodologia encerra, sobretudo, a construção de parâmetros para mensuração da eficiência no âmbito dos insumos energéticos (combustíveis) utilizados nos equipamentos na construção civil de grande porte.

Dessa forma, através desse novo indicador, aqui construído, é possível verificar dados mínimos que são os reais a serem buscados, considerando os dados ideais, os quais são os valores tomados como referência para melhor eficiência obtida em campo. Ressaltase que os dados foram obtidos por monitoramento via satélite.

Portanto, a partir da construção desse indicador se obtém resultados apresentados no capítulo 4 que espelham, principalmente, o atual modelo de consumo de combustível no setor em questão. 


\section{Resultados e Discussões}

\subsection{Introdução}

Como apresentado no capítulo 3, o método do trabalho partiu da análise do banco de dados construído a partir do fornecimento de informações da Empresa $X$, em que foi possível realizar a conversão de unidades dos consumos volumétricos para energia dispensada a cada equipamento utilizando valores de PCI e densidade de cada tipo de combustível analisado.

Com isso, foi possível levantar a distribuição dos insumos energéticos, onde as obras construção civil de grande porte detém a gestão de sua aplicação para cada tipo de uso final. Posteriormente, foi montado os parâmetros para a classificação de eficiência.

Diante de todo esse panorama metodológico, os resultados foram obtidos e divididos em: (i) principais insumos energéticos identificados; (ii) a destinação desses combustíveis e para qual equipamento foi utilizado; (iii) tipo de uso final; (iv) classificação de eficiência; e (v) potencial de redução do consumo dos insumos energéticos. Todos os pontos comentados serão apresentados a seguir.

As informações que deram origem aos dados, gráficos e figuras se encontram nos apêndices.

\subsection{Insumos energéticos}

Em termos de resultados dos insumos energéticos utilizados nos equipamentos operados no ano de 2011 nos projetos analisados, foi possível constatar uma predominância do consumo de óleo diesel quando comparado a outros insumos energéticos, assim como observado na Figura 9. 


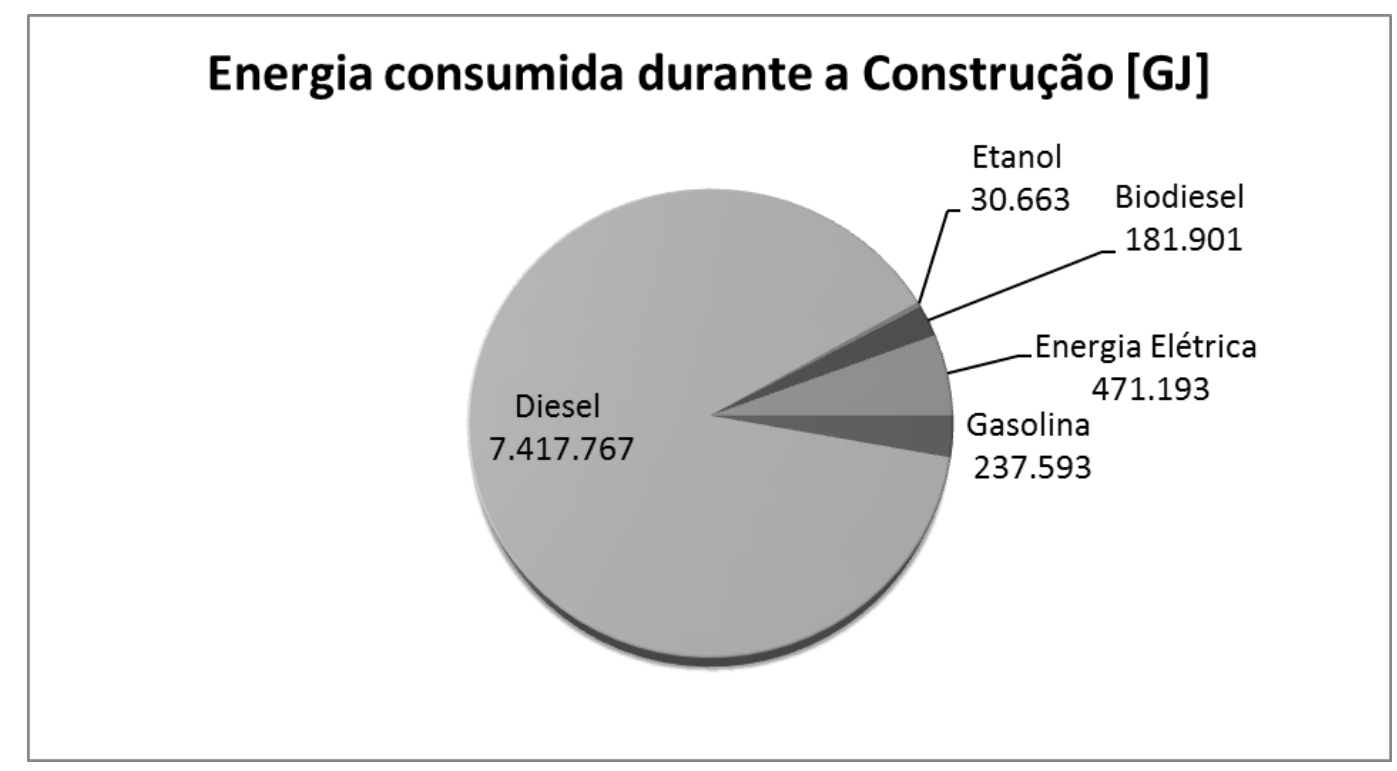

Figura 9 - Energia consumida durante a construção [GJ].

Com base na Figura 9 podemos verificar que diesel representa um percentual de $89,95 \%$ de consumo energético de diesel. A gasolina é direcionada prioritariamente para automóveis de pequeno porte, um volume menor é destinado para frota de caminhão e para geradores.

Já a energia elétrica é utilizada para a gerenciamento de canteiro, com usos finais convencionais, tais como ar condicionado, computadores e demais equipamentos para escritório temporário montado em obras.

O total de eletricidade contabilizado na Figura 9 provém da rede a partir do fornecimento da concessionária local de eletricidade. Nesta contabilização não foi incluída a energia elétrica obtida a partir da conversão em geradores a combustíveis como o diesel, uma vez que o combustível consumido para o funcionamento destes geradores já está contabilizado, evitando-se assim duplas contagens.

Em relação ao biodiesel, destaca-se que o mesmo deriva da parcela renovável na mistura de diesel conforme legislação própria de cada país. Quanto ao etanol, parte deriva do combustível propriamente dito utilizado pelos veículos e parte deriva da parcela renovável misturado à gasolina. Considerando este panorama, o principal resultado desse item foi ter apresentado a relevância do diesel em termos de tipo de combustível utilizado dentre os equipamentos estudados, o que permite direcionar os esforços para aumentar a eficiência no consumo deste combustível nas obras. 


\subsection{Demanda energética nos diferentes usos}

Esse item traz os resultados da demanda energética em GJ por tipo de equipamento estudado, conforme metodologia descrita no item 3.5. Optou-se pelo número de 15 tipos de equipamentos em razão de representarem o consumo de $93 \%$ do consumo total de combustível listado (apêndice 6.1).

Dentro desse quadro, ressalta-se que, em termos de unidades, $26 \%$ de todos os equipamentos são caminhões; 9.6\% são geradores; $8.2 \%$ são escavadeiras. Abaixo dessas classificações, nenhum outro equipamento tem mais de $5.5 \%$ de participação na amostra estudada.

Com os dados de consumo por tipo de equipamento, é possível se apropriar do conceito da Curva ABC para análise dos itens de maior relevância em termos de consumo energético do sistema.

A Figura 10 apresenta o consumo médio energético (correspondente ao uso de combustível) por tipo de equipamento. Como se observa, o equipamento caminhão (quase 7000 unidades), com 37\% de todo o consumo energético concentrado nessa categoria, traz o maior consumo dentre os demais tipos (apêndices 6.2 e 6.3).

Em seguida, a escavadeira e o gerador apresentam os consumos mais significativos, não pela taxa de consumo, mas, sobretudo, porque somam juntos 4.663 unidades. 


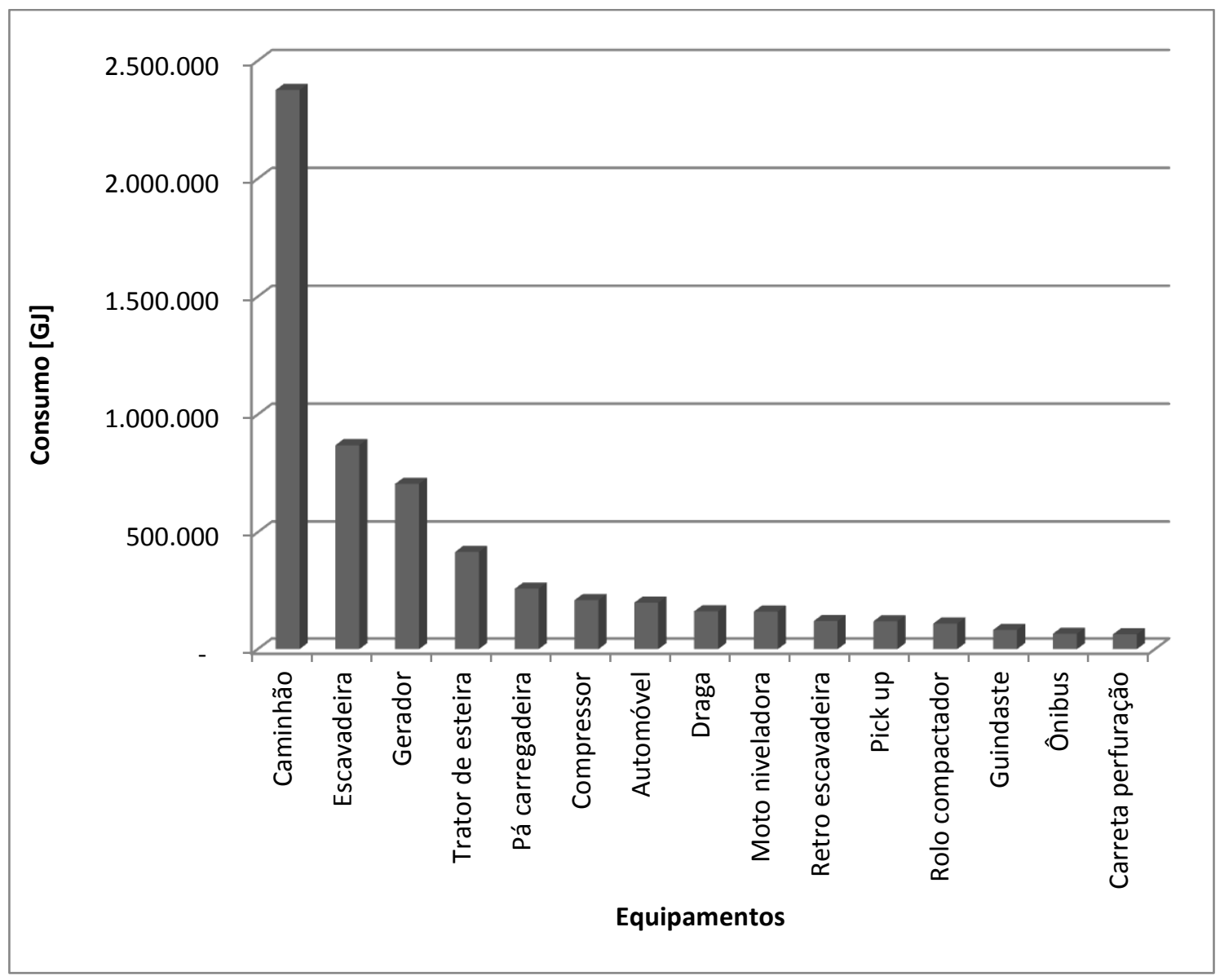

Figura 10 - Consumo energético por tipo de equipamento no ano de 2011 para o total de obras analisadas.

Apesar das 48 unidades em termos de quantidade de carretas de perfuração, o consumo energético desse equipamento foi inferior a $1 \%$, o que representa um pequeno consumo por unidade.

Por outro lado, a draga tem a menor quantidade, somente com 15 unidades, e apresenta o maior consumo por unidade (286.252 litros por unidade por ano).

A Figura 11 explicita a porcentagem acumulada do consumo energético dos tipos de equipamento. Essa figura traz os mesmos dados da Figura 10, analisados sob a participação relativa de cada equipamento dentro do panorama global. 


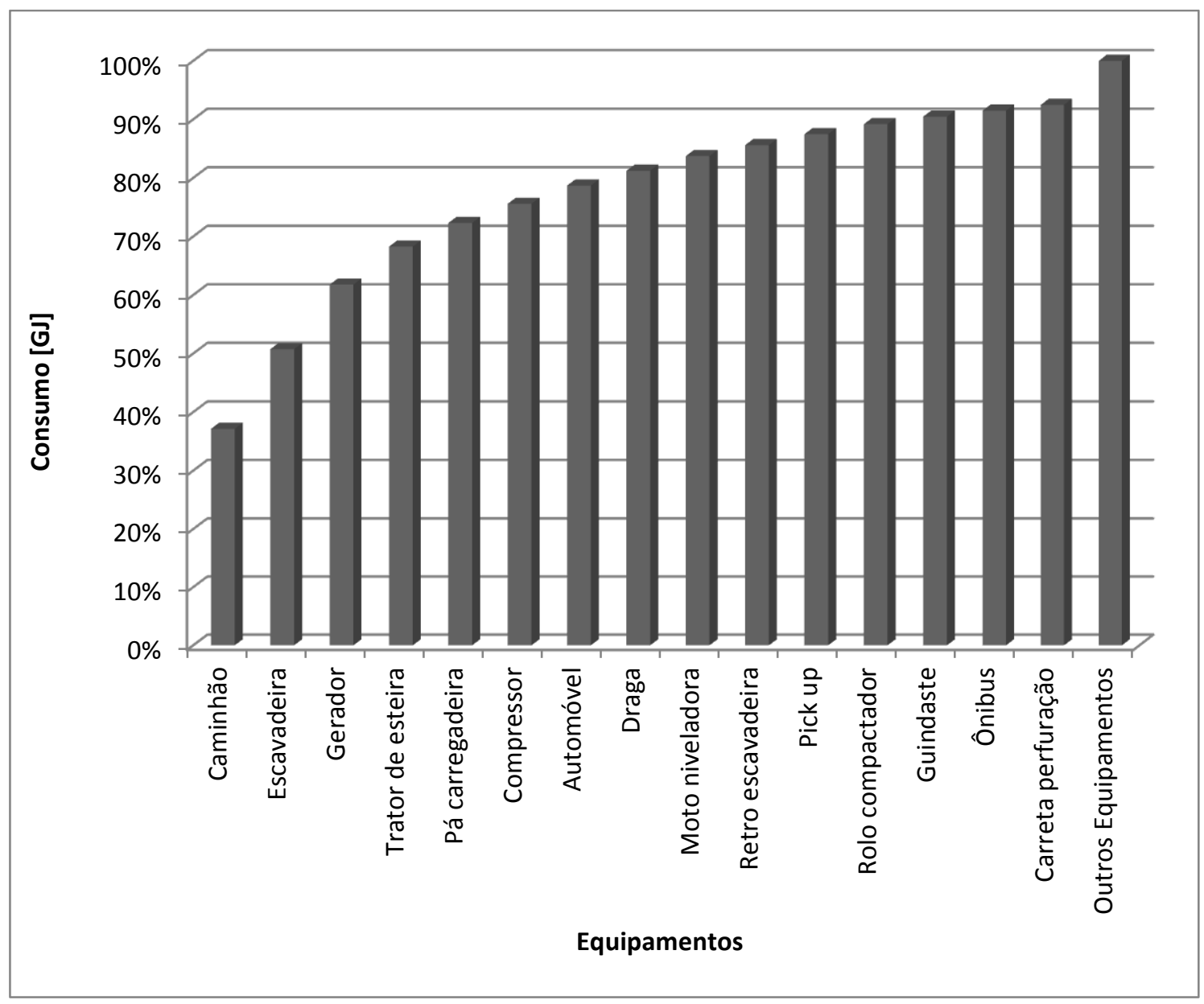

Figura 11 - Porcentagem acumulada de consumo energético por tipo de equipamento. Fonte: Elaboração própria

Para os equipamentos classificados como "outros", ressalta-se que representam $26 \%$ do total de equipamentos, porém com um consumo de apenas $7.5 \%$ do consumo total. Comparativamente, os caminhões com mesmo percentual de unidades possuem consumo de $34 \%$. Os dados que deram origem às Figura 10 e Figura 11 se localizam no apêndice 6.3.

Através dos comentários delineados, é possível verificar a preponderância dos caminhões no conjunto de equipamentos das obras de construção civil de grande porte.

A implicação desse resultado no estudo conduz à sugestão da aplicação de técnicas que melhorem a eficiência do sistema, seja através da manutenção desses veículos, seja na melhoria das técnicas de condução pelos motoristas. 


\subsection{Destinação da energia}

Utilizando os princípios do BEU abordados no item 3.6, Tabela 5, os resultados obtidos são focados nos usos finais dentro do setor em questão. A Tabela 7 aponta que a maior parte da energia fornecida pelos combustíveis utilizados em obras de construção é destinada para a geração de força motriz, o que significa mais de $90 \%$.

Ainda há uma parcela de $9 \%$ destinada à geração de eletricidade através de grupos geradores, que, por não haver uma categoria específica dentro da classificação do BEU, ficaram caracterizados como "outros".

Tabela 7 - Destinação da energia para cada uso final

\begin{tabular}{lrr}
\cline { 2 - 3 } Uso Final & Consumo [GJ] & \multicolumn{1}{c}{$\%$} \\
\cline { 2 - 3 } Força Motriz & $7.108 .257,14$ & $90,3 \%$ \\
Iluminação & $53.673,84$ & $0,7 \%$ \\
Outros & $705.899,07$ & $9,0 \%$ \\
\hline
\end{tabular}

Fonte: Elaboração própria

Uma pequena parcela, menos de $1 \%$, foi caracterizada como geração de iluminação, através das torres de iluminação.

Como observado, praticamente, todo o consumo energético está direcionado para o uso final "força motriz," que compreende um conjunto de atividades específicas que poderiam ser enquadradas em outras categorias de uso final.

No entanto, como a metodologia do trabalho se propôs a seguir o método descrito no item 3.6, em decorrência da concentração observada na técnica do BEU, optou-se por detalhar a classificação de força motriz no tocante a cada tipo de equipamento, e os resultados foram esmiuçados no item 4.5 .

\subsection{Classificação do indicador de eficiência}

No tocante aos resultados relacionados à classificação do indicador de eficiência, usando 1018 equipamentos monitorados via satélite e com informações de taxa consumo em litros por hora, foi possível gerar a Tabela 8. 
Com base nos dados de eficiência e com auxílio da Equação (5), mencionada no item 3.7, foi possível estimar a porcentagem de eficiência e a análise do desempenho dos equipamentos em questão.

Tabela 8 - Parâmetros para classificação de indicador de eficiência calculado

\begin{tabular}{|c|c|c|c|c|c|}
\hline $\begin{array}{l}\text { Classificação de } \\
\text { equipamentos }\end{array}$ & $\begin{array}{c}\text { Número de } \\
\text { equipamentos }\end{array}$ & Mediana $[\mathrm{l} / \mathrm{h}]$ & $\begin{array}{c}\text { Taxa de consumo } \\
\text { máximo } \\
\text { observado }[\mathrm{l} / \mathrm{h}]\end{array}$ & $\begin{array}{c}\text { Taxa de consumo } \\
\text { mínimo observado } \\
{[\mathrm{l} / \mathrm{h}]}\end{array}$ & $\begin{array}{c}\text { Indicador de } \\
\text { eficiência } \\
\text { calculado }\end{array}$ \\
\hline Gerador & 101 & 6,47 & 559,40 & 1,03 & $99,0 \%$ \\
\hline Guindaste & 37 & 6,19 & 76,14 & 1,37 & $93,5 \%$ \\
\hline Compressor & 59 & 14,96 & 203,30 & 1,19 & $93,2 \%$ \\
\hline Caminhão & 343 & 7,91 & 89,50 & 1,06 & $92,3 \%$ \\
\hline Cavalo mecânico & 24 & 10,15 & 92,16 & 1,05 & $90,0 \%$ \\
\hline Escavadeira & 100 & 13,40 & 86,05 & 1,22 & $85,6 \%$ \\
\hline Trator & 16 & 11,63 & 62,50 & 3,09 & $85,6 \%$ \\
\hline Torre de iluminação & 38 & 4,00 & 13,55 & 1,81 & $81,3 \%$ \\
\hline Compactador & 26 & 8,63 & 36,66 & 2,19 & $81,3 \%$ \\
\hline Empilhadeira & 14 & 4,16 & 14,90 & 1,59 & $80,7 \%$ \\
\hline Carregadeira de pneus & 28 & 8,37 & 38,02 & 1,13 & $80,4 \%$ \\
\hline Manipulador telescópico & 27 & 4,20 & 13,76 & 1,82 & $80,1 \%$ \\
\hline Trator de esteira & 52 & 16,90 & 71,18 & 1,04 & $77,4 \%$ \\
\hline Bomba & 9 & 14,69 & 26,32 & 10,89 & $75,4 \%$ \\
\hline Plataforma telescópica & 17 & 5,26 & 15,28 & 1,53 & $72,9 \%$ \\
\hline Plataforma elevatória & 7 & 5,88 & 13,76 & 2,85 & $72,2 \%$ \\
\hline Ônibus & 3 & 4,40 & 8,93 & 2,59 & $71,5 \%$ \\
\hline Retro escavadeira & 45 & 7,10 & 20,00 & 1,06 & $68,1 \%$ \\
\hline Misturador de concreto & 4 & 5,37 & 8,47 & 3,88 & $67,6 \%$ \\
\hline Mini carregadeira & 5 & 2,30 & 4,06 & 1,29 & $63,6 \%$ \\
\hline Carreta perfuração & 20 & 18,93 & 48,27 & 1,55 & $62,8 \%$ \\
\hline Máquina de solda & 3 & 11,48 & 18,30 & 7,03 & $60,5 \%$ \\
\hline Rebocador & 7 & 20,69 & 37,52 & 6,74 & $54,7 \%$ \\
\hline Mini escavadeira & 7 & 2,83 & 4,62 & 1,17 & $51,8 \%$ \\
\hline Outros & 2 & 5,09 & 8,34 & 1,85 & $50,0 \%$ \\
\hline Draga & 3 & $1.379,00$ & $2.065,00$ & 659,10 & $48,8 \%$ \\
\hline Moto niveladora & 17 & 14,24 & 25,13 & 1,07 & $45,3 \%$ \\
\hline Perfuratriz & 4 & 18,80 & 19,48 & 1,05 & $3,7 \%$ \\
\hline
\end{tabular}

Fonte: Elaboração própria 
Para cada equipamento há um dado de eficiência disponibilizado e que foi gerado durante sua operação no ano de 2011. Os dados nomeados como mediana constituem os valores medianos observados durante a operação, já os valores máximos representam os consumos máximos para dada classificação de equipamentos.

Os valores menores representam as menores taxas de consumo por hora observados no caso real apresentado. Estes valores estão sendo tomados como os melhores possíveis dentro de suas atividades.

Neste item, focou-se na descrição dos resultados apresentados pelos equipamentos que se apresentam em maior número, o que corresponde à ligação entre a eficiência calculada e o potencial de redução de consumo ainda disponível para o aumento do desempenho de cada equipamento dentro do conjunto.

O gerador apresentou o melhor resultado dentro do conjunto de equipamentos estudados. Com 101 equipamentos, chegou-se a 99,0\% de eficiência calculada, a mediana de consumo em litros por hora está próxima aos valores mínimos de consumo observados.

O indicador de eficiência energética do compressor é de 93,2\%, considerando 59 unidades, a mediana atingiu 14,96 l/h, o que significa que comparativamente ao gerador, a diferença na quantidade de equipamentos acarreta no resultado final do cálculo. Porque o compressor apresenta metade de equipamentos, mas o dobro do consumo médio.

O caminhão é o equipamento com maior quantidade de unidades analisadas, 343. Com uma eficiência calculada de 92,3\%, enxergam-se possibilidades de atuação no aumento da eficiência do consumo. A mediana ainda está distante do máximo consumo observado, porém ainda pode ser trabalhada para se aproximar do mínimo - 1,06 1/h.

A escavadeira tem uma realidade próxima ao dos caminhões. No entanto, o valor da mediana, comparativamente ao caminhão, é considerado elevado frente ao consumo médio dos outros equipamentos. Consequentemente, o espaço de atuação no desempenho ainda é bem maior que a do caminhão, pois os valores de mediana correspondentes à escavadeira estão mais afastados do seu consumo mínimo, 1,22 1/h.

$\mathrm{O}$ trator de esteira também apresenta um número significativo de unidades dentro da amostra realizada, com 52 unidades. O seu consumo máximo chegou a 71,18 1/h, enquanto o seu mínimo alcançou o valor de 1,04 1/h. Sua mediana chega a $16,9 \mathrm{l} / \mathrm{h}$, distante do mínimo. Esse resultado demonstra o potencial de atuação que pode ser trabalhado no presente equipamento.

Quanto maior a quantidade de equipamentos por classificação, maiores serão as possibilidades de chegar a um número mais realista de eficiência calculada e mais espaço 
se terá para trabalhar na redução do consumo de insumo energético, aprimorando a eficiência calculada do processo.

\subsection{Potencial de redução de consumo com base no indicador de eficiência criado}

Nesse item, assumiu-se que todos os equipamentos poderiam atender ao mínimo de consumo alcançável. Esse conceito se caracteriza como o mais baixo valor que o subconjunto de cada classificação de equipamentos apresentou.

Reforça-se o conceito de consumo mínimo como ideal a ser atingido, por exemplo, diante de uma curva de dispersão com dois valores equidistantes. A partir da mediana, apropria-se desses dois valores e ao se aperfeiçoar o sistema, obtém-se uma aproximação da linha da mediana com o valor mínimo. Como explorado na Figura 8, a partir da escala criada e adotada, o valor mínimo representa 100\%. Logo, quanto mais próximo a 100\%, mais eficiente os equipamentos se apresentam dentro das possibilidades do caso real.

Para o cálculo de potencial de redução do consumo de insumo energético, adotouse que o potencial mínimo observado seria a diferença entre $100 \%$ e a porcentagem de eficiência calculada e apresentada na Tabela 8, abordada no item 4.5.

Os resultados do potencial mínimo observado estão expostos na Tabela 9. Os resultados da Tabela 9 são inversos aos da Tabela 8, considerando especificamente a eficiência calculada.

Dessa forma, os equipamentos que mais se aproximam do comportamento ideal de consumo dentro desta escala criada apresentam um potencial de redução abaixo de $1 \%$. Cada equipamento tem uma escala própria. 
Tabela 9 - Potencial de redução com base no indicador de eficiência criado

\begin{tabular}{|c|c|}
\hline Equipamentos & Potencial de redução \\
\hline Gerador & $0,97 \%$ \\
\hline Guindaste & $6,45 \%$ \\
\hline Compressor & $6,81 \%$ \\
\hline Caminhão & $7,75 \%$ \\
\hline Cavalo mecânico & $9,98 \%$ \\
\hline Escavadeira & $14,36 \%$ \\
\hline Trator & $14,38 \%$ \\
\hline Torre de iluminação & $18,65 \%$ \\
\hline Compactador & $18,69 \%$ \\
\hline Empilhadeira & $19,34 \%$ \\
\hline Carregadeira de pneus & $19,62 \%$ \\
\hline Manipulador telescópico & $19,93 \%$ \\
\hline Trator de esteira & $22,62 \%$ \\
\hline Bomba & $24,63 \%$ \\
\hline Plataforma telescópica & $27,14 \%$ \\
\hline Plataforma elevatória & $27,77 \%$ \\
\hline Ônibus & $28,49 \%$ \\
\hline Retro escavadeira & $31,90 \%$ \\
\hline Misturador de concreto & $32,36 \%$ \\
\hline Mini carregadeira & $36,43 \%$ \\
\hline Carreta perfuração & $37,20 \%$ \\
\hline Máquina de solda & $39,47 \%$ \\
\hline Rebocador & $45,32 \%$ \\
\hline Mini escavadeira & $48,20 \%$ \\
\hline Outros & $50,00 \%$ \\
\hline Draga & $51,21 \%$ \\
\hline Moto niveladora & $54,73 \%$ \\
\hline Perfuratriz & $96,31 \%$ \\
\hline
\end{tabular}

Fonte: Elaboração própria

No caso dos geradores, tem-se que o resultado do potencial de redução foi $0,97 \%$, o que significa que uma parcela muito pequena desse tipo de equipamento está distante do mínimo esperado. Em resumo, para esse equipamento, a mediana está próxima do mínimo. Os geradores são os equipamentos que mais se aproximam do comportamento ideal de consumo dentro desta escala criada.

Essa afirmação pode também ser visualizada na Figura 12, em que a mediana do equipamento diz onde a maior parte dos dados está concentrada. Ou seja, mais próximo do 
mínimo, no caso dos geradores, o que comprova novamente o resultado de eficiência desse equipamento (para maiores detalhes, ver apêndice 6.11).

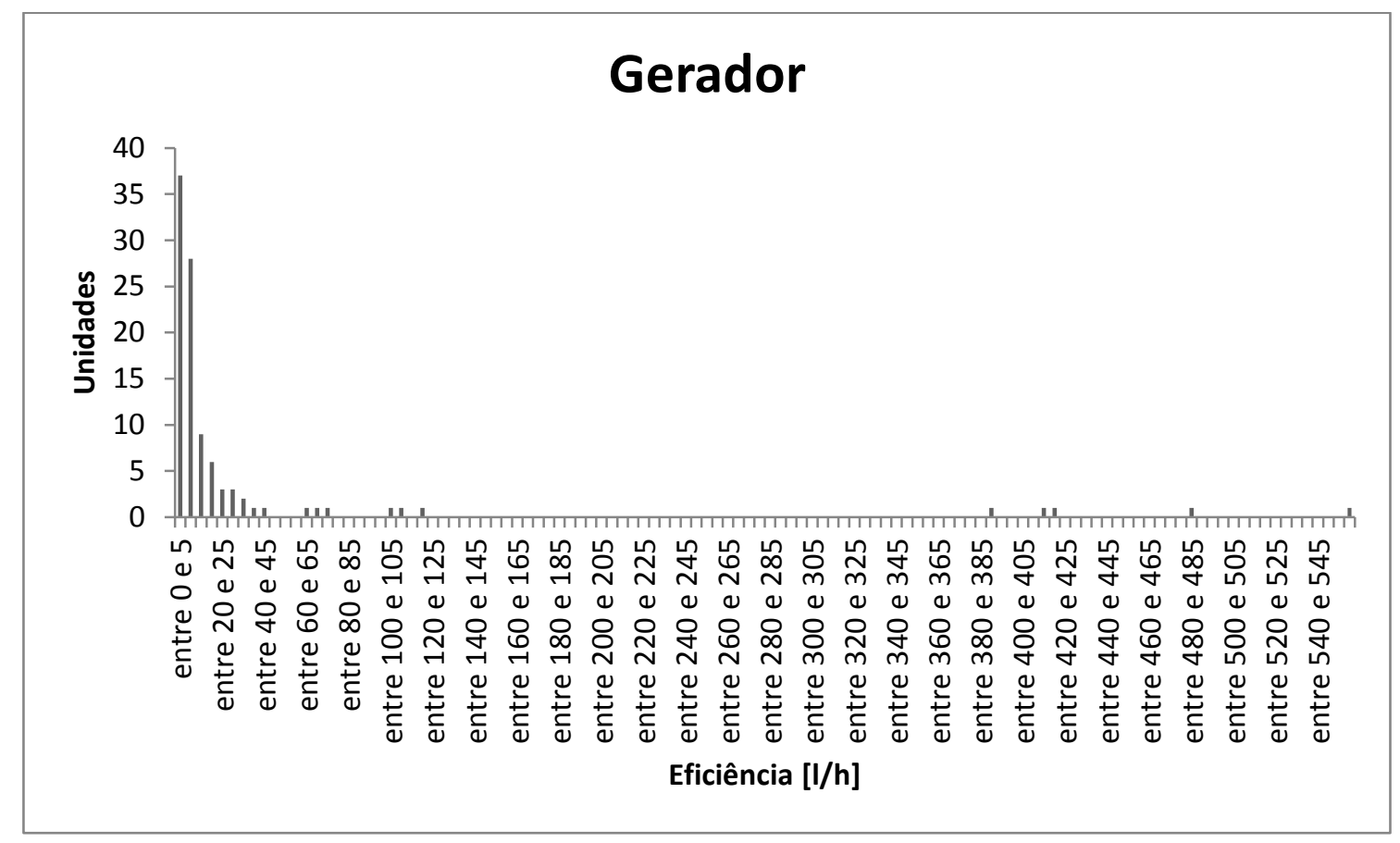

Figura 12 - Histograma de Eficiência do gerador

Fonte: Elaboração própria

Pode-se ressaltar, também, os dados de perfuratriz (com 04 unidades), que apresentaram altas variações entre os consumos observados, o que acarretou uma distância considerável entre valores mínimos e máximos, o que pode refletir no resultado final de 96,31\%. O subgrupo dos equipamentos denominados perfuratriz mostra como resultado final a tendência de alto potencial de redução de consumo.

Outro ponto interessante demonstrado na Tabela 9 é o subgrupo caminhão que traz um percentual de redução de 7,75\%. Esse resultado pode ser ilustrado na Figura 13, que traz o quantitativo dos caminhões mais concentrados ao mínimo, porém mais distanciados que os dados do gerador, constantes na Figura 12. 


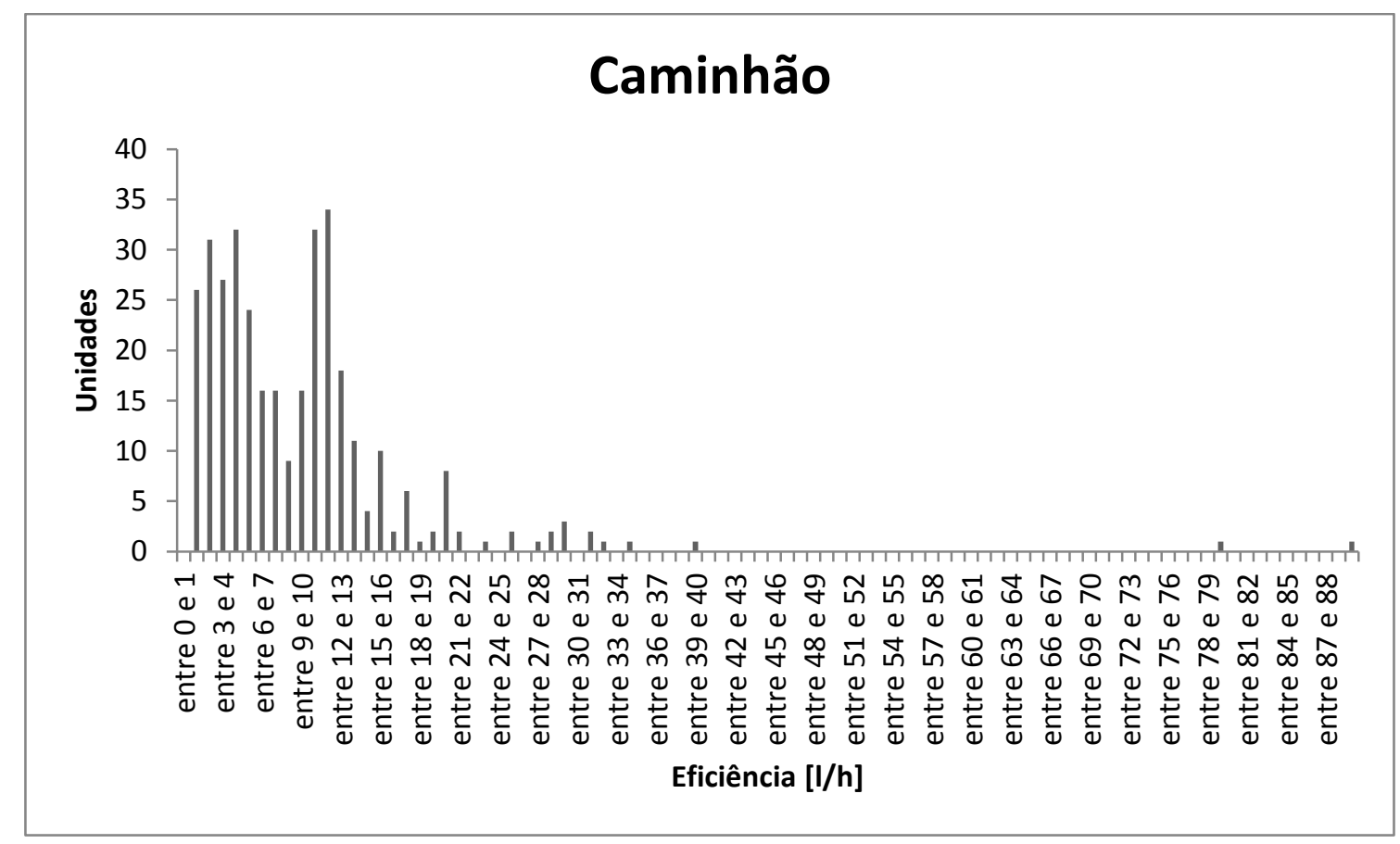

Figura 13 - Histograma de Eficiência do Caminhão

Fonte: Elaboração própria

Considerando que foram analisadas 343 unidades dentro de subgrupo caminhão (ver apêndice 6.12), pode-se averiguar que o impacto de programas de redução de consumo ocasionariam maiores ganhos comparativamente aos demais equipamentos.

As políticas podem ser referentes à manutenção preventiva, ações do operador do equipamento para evitar desgastes desnecessários em termos de forçar o motor da máquina ou deixá-lo ligado em períodos sem uso para finalidade específica, e o aprimoramento dos trajetos, como por exemplo, programas de logística eficiente.

A retroescavadeira tem 45 equipamentos, representando um quantitativo expressivo dentro das classificações de equipamentos apresentados e monitorados via satélite. Pode-se verificar diante dos resultados da Tabela 9, que o potencial de redução de consumo de $31,90 \%$ é significativo, principalmente, em relação ao caminhão e ao gerador.

A eficiência da retroescavadeira foi de $68 \%$ (ver Tabela 8), significando que a mediana está próxima à taxa de consumo média conforme observado na Figura 14. Os dados que servirão de base estão alocados no apêndice 6.13 . 


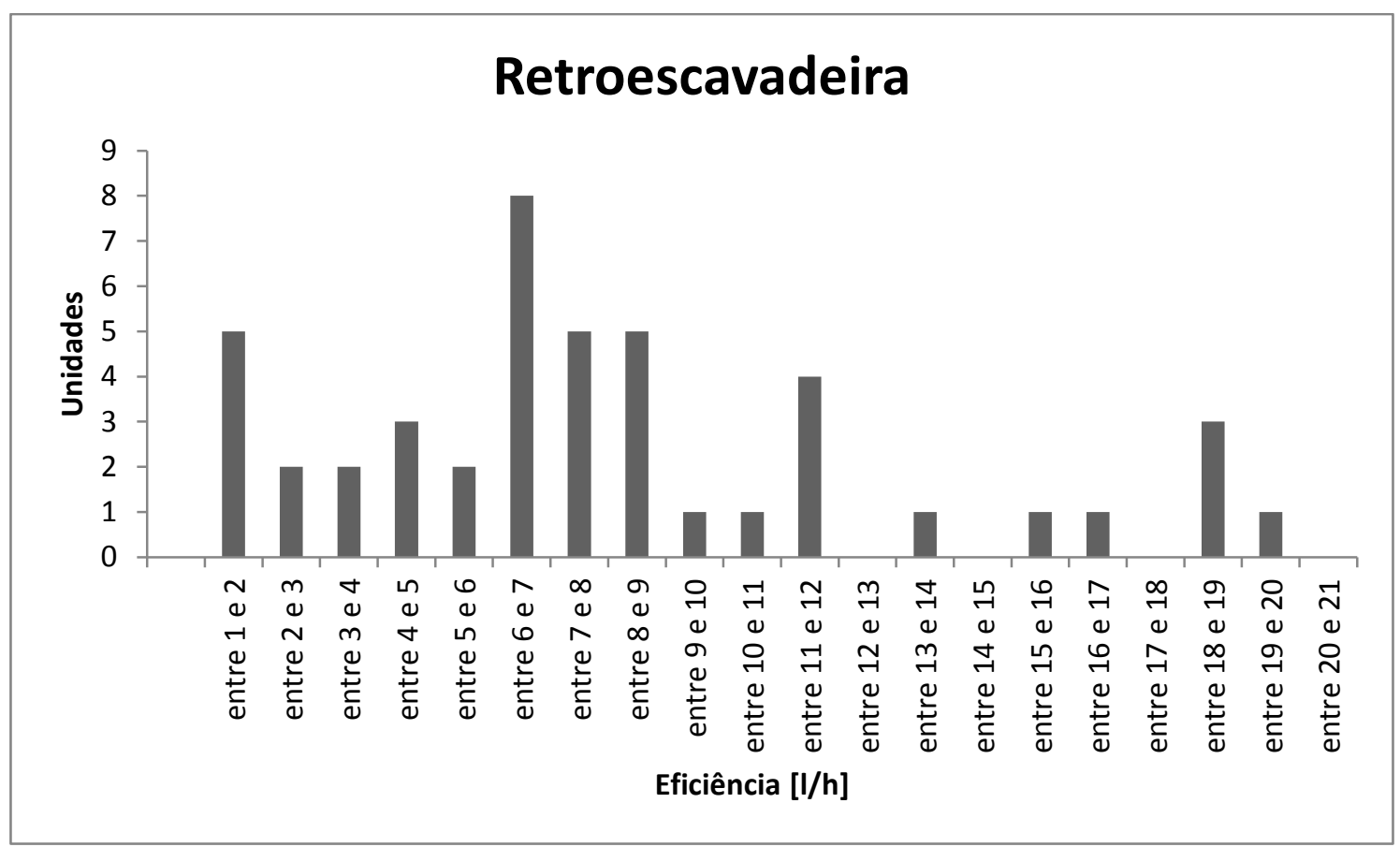

Figura 14 - Histograma de Eficiência do retroescavadeira

Fonte: Elaboração própria

Com o objetivo de consolidar os resultados comentados ao longo desse capítulo, a Tabela 10 traz um resumo dos principais resultados do trabalho.

Tabela 10 - Consolidação dos resultados

\begin{tabular}{ll}
\hline Principal Insumo Energético & Diesel \\
Principal Uso Final & Força Motriz \\
Principal Equipamento em termos de consumo global & Caminhão \\
Equipamento maior eficiência criada & Gerador \\
Equipamento com maior potencial de redução & Perfuratriz \\
\hline
\end{tabular}

Fonte: Elaboração própria

\subsection{Análise do EROI}

Para a análise do EROI baseou-se no consumo de combustíveis de forma isolada para cada projeto caracterizado como construção de hidrelétrica com informações suficientes de tempo de vida útil para geração de energia e potencia instalada. Chegou-se a um total de seis projetos com estas características que viabilizaram a análise. 
Tratou-se de somar todos os consumos de combustíveis apresentados na base de dados do ano de 2011 devidamente convertidos para unidades energéticas. As análises tratadas neste trabalho tomaram por base o uso da unidade de GJ, porém para a análise de EROI optou-se por utilizar MWh. Os totais obtidos estão apresentados na Tabela 11 a seguir.

Tabela 11 - Total de combustíveis consumidos durante a construção de Hidrelétricas no ano de 2011 dentro da base de dados utilizada.

\begin{tabular}{lrr}
\hline Projeto & $\begin{array}{r}\text { Total consumido em combustíveis fósseis } \\
\text { em 2011 [GJ] }\end{array}$ & $\begin{array}{c}\text { Total consumido em combustíveis fósseis } \\
\text { em 2011 [MWh] }\end{array}$ \\
\hline Hidrelétrica1 & 111.548 & 30.986 \\
Hidrelétrica2 & 241.506 & 67.085 \\
Hidrelétrica3 & 1.039 .740 & 288.817 \\
Hidrelétrica4 & 31.136 & 8.649 \\
Hidrelétrica5 & 72.111 & 20.031 \\
Hidrelétrica6 & 568.286 & 157.857 \\
\hline
\end{tabular}

Fonte: Elaboração própria.

Elaborou-se a estimativa de consumo energético de toda o período construtivo da obra considerando que estas levam 5 anos médios para serem construídas. A partir desta constatação é possível estimar qual o total de energia dispendida durante a construção destas hidrelétricas em termos de consumo de combustíveis. No presente caso o total apresentado em cinco anos utilizando os dados de 2011 como média foram de 2.867.120 MWh.

Para completar a análise é necessário o conhecimento do período de operação licenciado para cada projeto. A Tabela 12 apresenta uma estimativa do total de energia teoricamente gerada por cada hidrelétrica do conjunto. 
Tabela 12 - Estimativa do total de energia gerada durante a vida útil dos projetos em questão.

\begin{tabular}{cccr}
\hline \multicolumn{1}{c}{ Projeto } & Período de operação [anos] & $\begin{array}{c}\text { Capacidade } \\
\text { Instalada [MW] }\end{array}$ & Energia total produzida [MWh] \\
\hline Hidrelétrica1 & 30 & 456 & 119.836 .800 \\
Hidrelétrica2 & 21 & 80 & 14.716 .800 \\
Hidrelétrica3 & 35 & 3.150 & 965.912 .640 \\
Hidrelétrica4 & 35 & 1.820 & 558.012 .000 \\
Hidrelétrica5 & 35 & 334 & 102.312 .420 \\
Hidrelétrica6 & 25 & 2.160 & 473.040 .000 \\
\hline
\end{tabular}

Fonte: Elaboração própria.

A partir das informações descritas na Tabela 12, foi possível calcular a relação entre o total de energia proveniente de combustíveis diretos no período de construção e a estimativa do total de energia produzida pelas hidrelétricas em questão, obtendo-se um EROI médio de 779. Ou seja, existe uma relação de que para cada unidade energética inserida na atividade construtiva por combustíveis há um retorno de 779 unidades de energia produzidas durante a operação destas hidrelétricas.

Considerando que em média o EROI de hidrelétrica gira em torno de valores maiores que 100, conforme Tabela 2, e neste caso é considerada somente a queima de combustível, o número é factível, isto porque outros insumos de grande importância energética, além de fatores indiretos, conforme Figura 7, também são considerados em uma análise mais completa do caso.

Aplicando-se processos que visem a redução no consumo energético, aumentando a eficiência de equipamentos e reduzindo seus desperdícios, estes valores poderiam ser ainda mais representativos, reduzindo os investimentos energéticos durante a fase construtiva, tornando este indicador relevante.

\subsection{Considerações finais do capítulo}

Nesse capítulo foram explorados os resultados dentro da metodologia construída para os subgrupos de equipamentos, ou seja, a análise foi feita em conjunto e dentro de cada subgrupo. Equipamentos que apresentaram poucas unidades podem influenciar os resultados de eficiência observada e calculada dentro dos parâmetros descritos no capítulo 3. 
Conclui-se que a predominância do consumo de óleo diesel acarreta uma proposta de direcionamento de boas práticas para visar a redução de consumo desse insumo. Igualmente, tem-se que a demanda energética e com base no BEU, a maior parte da energia fornecida pelos combustíveis utilizados em obras de construção é destinada para a geração de força motriz, ocasionando a concentração da análise dos resultados na distribuição de consumo entre combustíveis.

Ademais, diante dos resultados do indicador de eficiência, infere-se que o gerador apresentou o melhor resultado dentro do conjunto de equipamentos estudados, chegando a $99,0 \%$ de eficiência calculada.

Também, o estudo deduz que o caminhão é o equipamento com maior quantidade de unidades monitoradas, 343, trazendo um maior espaço para atuação no aumento da eficiência do consumo, comparativamente aos demais equipamentos, facilitando a atuação com programas de eficiência. A perfuratriz trouxe numericamente o maior potencial de redução, todavia, com poucas unidades aonde se pode atuar.

Outro ponto que merece ser mencionado diz respeito à mecânica do motor, que não foi objeto do presente trabalho, porém entende-se que trabalhos futuros podem aproveitar desses resultados e replicar esse estudo, por exemplo, para novos equipamentos e diferentes grupos de controles. Novos estudos, também, podem se deter aos problemas de como o mercado dita os ganhos tecnológicos da parte mecânica. 


\section{Conclusão}

Em termos de considerações finais, no tocante ao principal insumo energético consumido pelos equipamentos estudados, o presente trabalho traz a preponderância do diesel enquanto grande fonte energética da construção civil de grande porte.

A partir da análise dos resultados foi possível constatar que a maior parte dos equipamentos utilizados no setor em questão geram força motriz para a realização de suas atividades através de motores a combustão. O consumo de óleo diesel quando comparado a outros insumos energéticos representa $89 \%$ frente aos $6 \%$ da eletricidade, e aos $5 \%$ de outros combustíveis.

Considerando o objetivo específico da dissertação, no tocante a obtenção do indicador de eficiência dos equipamentos, geradores, guindastes, compressores e caminhões foram os itens que apresentaram maiores índices de eficiência, com 99,0\%, 93,5\%, 93,2\% e 92,3\%, respectivamente. Esses resultados mostram que a maior parte destes equipamentos opera próximo ao ótimo do consumo por hora registrado no projeto.

O equipamento caminhão é o maior consumidor de diesel das obras analisadas, porém apresenta também uma eficiência elevada. Mesmo apresentando resultados representativos, recomenda-se ainda uma atenção especial aos caminhões, já que representam $37 \%$ de todo o consumo energético direto de uma construção civil de grande porte. Ainda assim são necessárias medidas para tornar essa eficiência ainda melhor, devido ao grande número de unidades apresentadas.

Equipamentos tais como draga, motoniveladora e perfuratriz apresentaram os menores índices de eficiência, com 48,8\%, 45,3\% e 3,7\%, porém isso pode ser explicado em função do tipo de atividade realizada, características próprias do terreno, método construtivo ou até mesmo especificidades de cada atividade que os equipamentos realizam.

A partir da análise do Retorno Sobre o Investimento de Energia - EROI das obras das hidrelétricas inseridas no sistema, o trabalho demonstrou que, de fato, existe um alto retorno energético tendo por base a análise dos combustíveis usados em suas construções. O retorno apresentado pode se tornar maior aplicando-se projetos de redução de consumo energético e melhorando a eficiência dos equipamentos operados nestas obras.

Por fim, pode-se concluir que são necessárias aplicações de boas práticas de redução dos consumos energéticos em obras de construção civil de grande porte tendo em 
vista a abertura desta oportunidade visando redução de custos e de gastos de recursos naturais.

Essas práticas devem ainda ser mais estudadas e aplicadas aos projetos visando avalizar a aplicabilidade de cada medida que vise a redução dos consumos e a melhoria das eficiências.

Futuros trabalhos também poderão se aprofundar nos ganhos econômicos e ambientais, envolvendo também as reduções de emissões de gases de efeito estufa, por exemplo, que esta melhora na eficiência e a redução dos volumes de combustíveis queimados poderão acarretar tendo em vista o número crescente de obras de grande porte e a importância destes projetos no panorama nacional.

Poderão também verificar-se em estudos futuros a relação direta entre a redução das queimas de combustíveis fósseis e a redução de recursos dispendidos, além de minimização de externalidades negativas como emissão de gases poluentes e emissão de gases de efeito estufa, representando não só um ganho monetário, como também ganho ambiental. 


\section{REFERÊNCIAS}

ASSOCIAÇÃO BRASILEIRA DE NORMAS TÉCNICAS. ABNT NBR ISO 50001:2011 Sistemas de gestão da energia - Requisitos com orientações para uso. Rio de Janeiro, 2011.

AGÊNCIA NACIONAL DO PETRÓLEO, GÁS NATURAL E BIOCOMBUSTÍVEIS. Resolução no 07, de 19 de março de 2008. DOU 20 de Março de 2008.

Resolução n 36, de 06 de dezembro de 2005. DOU 07 de dezembro de 2005.

ADVANCED PROCUREMENT FOR UNIVERSITIES AND COLLEGES. Guide to Procuring Construction Projects, 2008. Londres. Disponível em: <http://www.apucscot.ac.uk/uploads/Docs/pdf/Guide\%20to\%20Procuring\%20Construction\%20Projects\%20 29-6-11.pdf>. Acesso em: 20 de Maio de 2014.

AUSTRALIAN GOVERNMENT - DEPARTMENT OF RESOURCES, ENERGY AND TOURISM. Analyses of Diesel Use for Mine Haul and transport operations. 2011. Disponível em: <http://www.ret.gov.au/energy/Documents/energyefficiencyopps/resmaterial/Analysis-of-Diesel-Use.pdf>. Acesso em: 20 de Outubro de 2012.

Energy Savings Measurement Guide: How to Estimate, Measure, Evaluate and Track Energy Eficiency Opportunities. 2008. Disponível em: <http://www.ret.gov.au/energy/Documents/energyefficiencyopps/ESMG\%20-\%20Ver sionOne_Web20080520104658.pdf>. Acesso em: 20 de Outubro de 2012.

BIOFUELS DIGEST. Biofuels Mandates Around the World: 2014. 2014. Disponível em: <http://www.biofuelsdigest.com/bdigest/2013/12/31/biofuels-mandates-around-theworld-2014/>. Acesso em: 21 de Abr. 2013.

BRASIL. Decreto n. ${ }^{\circ} 4.059$, de 19 de dezembro de 2001, Regulamenta a Lei n. ${ }^{0} \mathbf{1 0 . 2 9 5}$, de 17 de outubro de 2001, que dispõe sobre a Política Nacional de Conservação e Uso Racional de Energia. Diário Oficial da República Federativa do Brasil, Brasília, DF, v. 138, n. 242, p.5. 2001, Seção 1.

Lei $\mathrm{n}^{\circ} 11.097$ de 13 de janeiro de 2005. Dispõe sobre a introdução do biodiesel na matriz energética brasileira. Diário Oficial da República Federativa do Brasil, Brasília, DF, de 14 de Jan. 2005, p.8. Seção 1. 
BRASIL, N. I et al. Processamento de Petróleo e Gás - Petróleo e seus derivados, processamento primário, processos de refino, petroquímica e meio ambiente. Petrobrás. 2012. Rio de Janeiro: LTC, 2012. ISBN 978-85-216-1996-3.

CARBON DISCLOSURE PROJECT. 2011. Disponível em: <http://www.cdproject.net>. Acesso em: 10 out. 2012.

CONSELHO INTERMINISTERIAL DO AÇÚCAR E DO ÁLCOOL. Resolução nº 37, de 27 de jun. 2007. DOU 28 de Junho de 2007.

COLE, R. J.; KERNAN, P. C. Life-Cycle Energy Use in Office Buildings. Building and Environment, Volume 31, no 4, página 307 - 317. 1996. Disponível em: <http://ametme.mnsu.edu/UserFilesShared/SolarWall/Benchmarking/Misc/Life-

Cycle\%20Energy\%20Use\%20in\%20Office\%20Buildings.pdf $>$. Acesso em: 10 de Outubro de 2012.

COLE, R.; Energy and Greenhouse Gas Emissions Associated With the Construction of Alternative Structural Systems. Building and Environment, Volume 34, Issue 3, 1, $\begin{array}{llllll}\text { página } & 335 & - & 348 . & 1998 . & \text { Disponível }\end{array}$ <http://www.sciencedirect.com/science/article/pii/S0360132398000201>. Acesso em: 10 de Outubro de 2012.

DELOITTE. EPoC 2010 - European Powers of Construction. 2011. Disponível em: $<$ http://www.deloitte.com/assets/DcomFrance/Local\%20Assets/Documents/Votre\%20Secteur/Immobilier/EPoC_European_Powe rs_of_Construction_2010.pdf>. Acesso em: 25 de Outubro de 2012.

DIEESE, Estudo Setorial da Construção. Estudos e Pesquisas, 2012. Disponível em: <http://www.dieese.org.br/estudosetorial/2012/estPesq65setorialConstrucaoCivil2012.pdf> . Acesso em: 01 de Março de 2014.

DIMOUDI, A.; TOMPA, C. Energy and Environmental Indicators Related to Construction of Office Buildings. Resources, Conservation and Recycling. Volume 53, Issues 1-2, página $86-95.2008$.

ENCORD. Construction $\mathbf{C O}_{2} \mathbf{e}$ Measurement Protocol. 2012. Disponível em: <http://www.encord.org/wp-content/uploads/2012/06/ENCORD_CO2e_Protocol.pdf〉. Acesso em: 10 de Outubro de 2012. 
ENVIRONMENTAL PROTECTION AGENCY. National Action Plan for Energy Efficiency: Model Energy Efficiency Program Impact Evaluation Guide. 2007. Disponível em: <www.epa.gov/eeactionplan>. Acesso em: 10 out. 2012.

Potential for Reducing Greenhouse Gas Emissions in the Construction Sector. 2009. Disponível em: <http://www.epa.gov/sectors/pdf/construction-sectorreport.pdf $>$. Acesso em: 10 de Jul. 2012

FÓRUM CLIMA. Guia Metodológico para Inventário de Emissões de Gases de Efeito Estufa na Engenharia e Construção. 2013. Disponível em: <http://forumempresarialpeloclima.org.br/wp-content/uploads/2013/08/Guia.pdf>. Acesso em: 01 de Mar. 2014.

GARTNER, E. M.; SMITH, M. A.; Energy Costs of House Construction. Energy Policy. Volume 4, Issue 2, página $144-157.1976$. Disponível em: <http://www.sciencedirect.com/science/article/pii/0301421576900070>. Acesso em: 10 out. 2012.

GATELY, M. The EROI of U.S. offshore energy extraction: A net energy analysis of the Gulf of Mexico. Ecological Economics. 2007. Disponível em: < http://www.sciencedirect.com/science/article/pii/S0921800907001036>. Acesso em: 07 Maio 2014.

GHG PROTOCOL BRASIL. Média anual da mistura de combustíveis renováveis nos combustíveis fósseis. FGV - Faculdade Getúlio Vargas. 2012.

GOLDENBERG, J. Energia e Desenvolvimento. Estudos avançados, v.12, n. 33, 1998. Disponível em: <http://www.scielo.br/scielo.php?script=sci_arttext\&pid=S010340141998000200002>. Acesso em :01 nov. 2012.

(b). Energia, Meio Ambiente e Desenvolvimento. Edusp, São Paulo, 1998.

HARBert, G.; CASTILlO, E.; VINCENS, E.; MOREL, J. C. Power: A New Paradigm for Energy Use in Sustainable Construction. Ecological indicators. 2012. Disponível em: <http://www.sciencedirect.com/science/article/pii/S1470160X12001240>. Acesso em: 10 out. 2012.

HERENDEEN, R. A. Notes and Comments on the Energy Cost of Building Construction. Energy and Buildings. Volume 1, Issue 1, pag 95-96, 1977. Disponível em: <http://www.sciencedirect.com/science/article/pii/0378778877900184>. Acesso em: 10 out. 2012. 
INSTITUTO BRASILEIRO DE GEOGRAFIA E ESTATÍSTICA Pesquisa Anual da Indústria da Construção. 2010. Disponível em: <ftp://ftp.ibge.gov.br/Industria_da_Construcao/Pesquisa_Anual_da_Industria_da_Construc ao/2010/paic2010.pdf>. Acesso em: 10 out. 2012.

INTERNATIONAL ENERGY AGENCY. Technology Roadmap Biofuels for Transport. 2011. Disponível em: <http://www.iea.org/publications/freepublications/publication/biofuels_roadmap.pdf > . Acesso em: 21 de Abril de 2013.

INSTITUTE FOR BUILDING EFFICIENCY. Energy Efficiency Indicator: 2012 EEI: Brazil Results. 2012. Disponível em: <http://www.institutebe.com/Energy-EfficiencyIndicator/2012-EEI-Brazil-Results.aspx?lang=en-US>. Acesso em: 10 de Outubro de 2012.

INTERGOVERNMENTAL PANEL ON CLIMATE CHANGE. Guidelines for National Greenhouse Gas Inventories. Volume 1 General Guidance and Reporting. Capítulo 3: Uncertainties. 2006. Disponível em: <http://www.ipccnggip.iges.or.jp/public/2006gl/pdf/1_Volume1/V1_3_Ch3_Uncertainties.pdf >. Acesso em: 21 de Abril de 2013.

IPCC Renewable Energy Sources and Climate Change Mitigation (SRREN). 2012. Cambridge University Press, UK. pp 1076. Disponível em: <http://srren.ipccwg3.de/report/IPCC_SRREN_Full_Report.pdf>. Acesso em: 15 mar. 2014.

Reference Document on Best Available Techniques for Energy Efficiency. 2009. Disponível em: <http://eippcb.jrc.ec.europa.eu/reference/BREF/ENE_Adopted_022009.pdf>. Acesso em: 10 out. 2012.

INTERNATIONAL PETROLEUM INDUSTRY ENVIRONMENTAL CONSERVATION ASSOCIATION. Addressing Uncertainty in Oil and Natural Gas Industry Greenhouse Gas Inventories, Technical Considerations and Calculation Methods. Disponível em: <http://www.ipieca.org/sites/default/files/publications/addressing_uncertainty_pilot.pdf>. Acesso em: 21 abr. 2013.

INTERNATIONAL ORGANIZATION STANDARDIZATION. Win the energy challenge with ISO 50001. 2011. Disponível em: <http://www.iso.org/iso/iso_50001_energy.pdf> Acesso em: 01 ago. 2012.

INTERNATIONAL STANDARD INDUSTRIAL CLASSIFICATION OF ALL ECONOMIC ACTIVITIES - ISIC. Detailed structure and explanatory notes - ISIC 
Rev.

3.1.

2014.

Disponível

em:

$<$ http://unstats.un.org/unsd/cr/registry/regcs.asp? $\mathrm{Cl}=17 \& \mathrm{Lg}=1 \& \mathrm{Co}=45>$. Acesso 30 out. 2014.

JUNNILA, S. An Environmental Impact of an Office Building Throughout its Life Cycle. Espoo, Helsinki University of Technology Construction Economics and Management (Doctoral Dissertation). Espoo. 2004. Disponível em: $<$ https://aaltodoc.aalto.fi/bitstream/handle/123456789/2462/isbn9512272857.pdf?sequence =1>. Acesso em: 10 out. 2012 .

MACEDO, M. L. A. Análise comparativa dos processos de certificação energética de edifícios existentes aplicados na União Europeia. Mestrado Integrado em Engenharia Civil - 2008/2009 - Departamento de Engenharia Civil, Faculdade de Engenharia da Universidadedo Porto, Porto, Portugal, 2008. Disponível em: <http://repositorioaberto.up.pt/bitstream/10216/59684/1/000136597.pdf>. Acesso em: 15 out. 2012.

MINISTÉRIO DE ESTADO DA AGRICULTURA, PECUÁRIA E ABASTECIMENTO. Portaria $\mathrm{n}^{\circ} 678$ de 31 de agosto de 2011. DOU 01 de Setembro de 2011.

MINISTÉRIO DE MINAS E ENERGIA. Balanço de Energia Útil 2005, ano base 2004. Brasília, 2005.

— Balanço Energético Nacional. Brasil. 2013. Disponível em: <https://ben.epe.gov.br/downloads/Relatorio_Final_BEN_2013.pdf > . Acesso em: 22 mar. 2014.

Brasil. 2011. Disponível em: <http://www.mme.gov.br/mme/galerias/arquivos/PlanoNacEfiEnergetica.pdf >. Acesso em: 24 out. 2012.

MINISTÉRIO DE MINAS E ENERGIA \& EMPRESA DE PESQUISA ENERGÉTICA. Plano Decenal de Expansão de Energia 2022. Brasil. 2013. Disponível em: < http://www.epe.gov.br/PDEE/20140124_1.pdf>. Acesso em: 12 fev. 2014.

Projeção da demanda de energia elétrica. Brasil. 2012. Disponível em: <http://www.epe.gov.br/mercado/Documents/S\%C3\%A9rie\%20Estudos\%20de\%20Energi a/20130117_1.pdf>. Acesso em: 12 fev. 2014.

MONTEIRO FILHA, D. C.; COSTA, A. C. R.; ROCHA, E. R. P. Perspectivas e Desafios para Inovar na Construção Civil. BNDES Setorial 31, página 353 - 410. 2010. 
<http://www.bndes.gov.br/SiteBNDES/export/sites/default/bndes_pt/Galerias/Arquivos/co nhecimento/bnset/set3110.pdf >. Acesso em :10 out. 2012.

MURPHY D. J.; HALL, C. A. S. Year in Review — EROI or Energy Return on (Energy) Invested. Annals of the New York academy of Sciences , v.1185, p.102-118, Jan. 2010. Disponível

em: <http://www.soest.hawaii.edu/GG/FACULTY/ITO/GG410/EROI_Future_Energy_Sources /Murphy_EROI_AnNYAcSci10.pdf>. Acesso em: 12 mar. 2014.

NATIONAL CENTER FOR AGRICULTURAL UTILIZATION RESEARCH. The Biodiesel Handbook. USA, Illinois. 2005.

NATIONAL RENEWABLE ENERGY LABORATORY. Biodiesel Handling and Use Guidelines, US Department of Energy. 2009. Disponível em: <http://www.biodiesel.org/docs/using-hotline/nrel-handling-and-use.pdf?sfvrsn=4>. Acesso em: 13 maio 2014.

OLIVEIRA, P. M. C.; DECHOUM, K. Facilitando a Compreensão da Segunda Lei da Termodinâmica. Revista Brasileira de Ensino de Física, v. 25, n. 4, p.359, dez. 2003 Disponível em: <http://www.scielo.br/pdf/rbef/v25n4/a04v25n4>. Acesso em: 22 de Abril de 2014.

PEREIRA, E.; PIMENTEL, L. L. Eficiência Energética Nas Edificações Certificações e Políticas Públicas. In: ENCONTRO DE INICIAÇÃO CIENTÍFICA DA PUC CAMPINAS, 15., 2010, Campinas. Anais... Disponível em: <http://www.puccampinas.edu.br/websist/portal/pesquisa/ic/pic2010/resumos/2010924_161839_502023879 _resman.pdf>. Acesso em: 05 set. 2012.

SANCHEZ, G. F; LOPEZ, F. R. A Methodology to Identify Sustainability Indicators in Construction Project Management - Application to Infrastructure Projects in Spain. Ecological Indicators, v.10, n.6, p. 1193-1201, Nov. 2010. Disponível em: <http://www.sciencedirect.com/science/article/pii/S1470160X10000798>. Acesso em: 20 out. 2012.

SIMÕES MOREIRA, J. R. Aplicações da Termodinâmica. Escola Politécnica da USP Departamento de Engenharia Mecânica. 2012.

SUZUKI, M.; OKA, T. Estimation of Life Cycle Energy Consumption and $\mathrm{CO}_{2}$ Emission of Office Buildings in Japan. Journal of Energy and Buildings,v.28, p. 33-41, 1998. Disponível em: <http://www.sciencedirect.com/science/article/pii/S0378778898000103\#>. Acesso em: 10 out. 2012. 
TICIANELli, E. A.; GONZALEZ, E. R. Células a Combustão: uma alternativa promissora para a geração de eletricidade. Química Nova, v.12, n.3, p. 268 - 272, 1989. Disponível em: <quimicanova.sbq.org.br/qn/qnol/1989/vol12n3/v12_n3_\%20(10).pdf>. Acesso em: 22 abr. 2014.

UNITED NATIONS ENVIRONMENT PROGRAMME. BUILDINGS AND CLIMATE CHANGE Status, Challenges and Opportunities. 2007. Disponível em: <http://www.unep.fr/shared/publications/pdf/DTIx0916xPA-BuildingsClimate.pdf>. Acesso em: 10 out. 2012.

VARUN; SHARMA, A.; SHREE, V.; NAUTIYAL, H. Life Cycle Environmental Assessment of an Educational Building in Northern India: A Case Study. Sustainable Cities and Society, v.4, p. 22-28, 2012. Disponível em: <http://www.sciencedirect.com/science/article/pii/S2210670712000170>. Acesso em: 10 out. 2012.

VOLKSNET. Guia Institucional Volksnet. 2014. Disponível em: <http://www.volksnet.com.br/institucional/o_que_e.jsf>. Acesso em: 13 mar. 2014.

YAN, H.; SHEN, Q.; FAN, L. C. H.; WANG, Y.; ZHANG, L. Greenhouse Gas Emissions in Building Construction: A Case Study of One Peking in Hong Kong. Building and Environment, v. 45, n.4, p. 949-955, 2010. Disponível em: <http://www.sciencedirect.com/science/article/pii/S0360132309002649>. Acesso em: 10 out. 2012.

YOSHINO, R. T.; SOUZA, R. M. Barreiras aos Programas de Conservação de Energia no Brasil. In: ENCONTRO NACIONAL DE ENGENHARIA DE PRODUÇÃO, 21. , 2001, Salvador. Anais... Porto Alegre: ABREPO, 2001. Disponível em: <http://www.abepro.org.br/biblioteca/ENEGEP2001_TR103_0282.pdf〉. Acesso em: 10 out.2012. 


\section{Apêndices}

\subsection{Consumo por equipamentos}

\begin{tabular}{ccccc}
\hline Quantidade & Equipamento & Consumo [I] em 2011 & Litros por unidade & \% \\
\hline 6.780 & Caminhão & 63.442 .505 & 164.662 & $37,05 \%$ \\
2.150 & Escavadeira & 23.214 .865 & 10.798 & $13,56 \%$ \\
2.513 & Gerador & 18.737 .823 & 7.456 & $10,94 \%$ \\
554 & Trator de esteira & 11.080 .299 & 20.001 & $6,47 \%$ \\
472 & Pá carregadeira & 6.906 .963 & 14.633 & $4,03 \%$ \\
1.275 & Automóvel & 6.016 .441 & 4.719 & $3,51 \%$ \\
1.407 & Compressor & 5.558 .480 & 3.951 & $3,25 \%$ \\
15 & Draga & 4.293 .782 & 286.252 & $2,51 \%$ \\
324 & Moto niveladora & 4.281 .236 & 13.214 & $2,50 \%$ \\
1.065 & Pick up & 3.190 .777 & 2.996 & $1,86 \%$ \\
1.132 & Retro escavadeira & 3.189 .060 & 2.817 & $1,86 \%$ \\
513 & Rolo compactador & 2.902 .954 & 5.659 & $1,70 \%$ \\
610 & Guindaste & 2.182 .715 & 3.578 & $1,27 \%$ \\
467 & Oonibus & 1.751 .269 & 3.750 & $1,02 \%$ \\
48 & Carreta perfuração & 1.682 .098 & 35.044 & $0,98 \%$ \\
6.796 & Outros Equipamentos & 12.826 .815 & 263.909 & $7,49 \%$ \\
\hline
\end{tabular}


6.2 Consumo por tipo de caminhão

\begin{tabular}{ccccc}
\hline Quantidade & Equipamento & Consumo [l] & Litros por unidade & \% \\
\hline 3.032 & Caminhão basculante & 29.402 .370 & 9.697 & $17,17 \%$ \\
1.301 & Caminhão & 13.103 .131 & 10.072 & $7,65 \%$ \\
100 & Caminhão comboio & 4.552 .492 & 45.525 & $2,66 \%$ \\
409 & Caminhão tanque & 5.611 .920 & 13.721 & $3,28 \%$ \\
453 & Caminhão guindaste & 2.645 .764 & 5.841 & $1,54 \%$ \\
587 & Caminhão betoneira & 2.554 .071 & 4.351 & $1,49 \%$ \\
293 & Caminhão pipa & 1.644 .694 & 5.613 & $0,96 \%$ \\
46 & Caminhão articulado & 1.019 .074 & 22.154 & $0,60 \%$ \\
297 & Caminhonete & 1.455 .073 & 4.899 & $0,85 \%$ \\
73 & Caminhão plataforma & 483.983 & 6.630 & $0,28 \%$ \\
25 & Caminhão de reboque & 116.825 & 4.673 & $0,07 \%$ \\
26 & Caminhão baú & 107.939 & 4.151 & $0,06 \%$ \\
26 & Caminhão bomba & 120.761 & 4.645 & $0,07 \%$ \\
62 & Caminhão cavalo mecânico & 431.759 & 6.964 & $0,25 \%$ \\
11 & Caminhão de lixo & 51.139 & 4.649 & $0,03 \%$ \\
14 & Caminhão lança concreto & 51.884 & 3.706 & $0,03 \%$ \\
12 & Caminhão limpa fossa & 74.411 & 6.201 & $0,04 \%$ \\
13 & Caminhão munck & 15.215 & 1.170 & $0,01 \%$ \\
\hline
\end{tabular}


6.3 Consumo energético por tipo de equipamento [GJ]

\begin{tabular}{ccccc}
\hline Quantidade & Equipamento & Consumo [GJ] & GJ por unidade & $\%$ \\
\hline 6.780 & Caminhão & 2.375 .830 & 6.099 & $37,14 \%$ \\
2.150 & Escavadeira & 869.890 & 405 & $13,60 \%$ \\
2.513 & Gerador & 705.899 & 281 & $11,04 \%$ \\
554 & Trator de esteira & 415.466 & 750 & $6,50 \%$ \\
472 & Pá carregadeira & 258.302 & 547 & $4,04 \%$ \\
1.407 & Compressor & 209.523 & 149 & $3,28 \%$ \\
1.275 & Automóvel & 198.754 & 156 & $3,11 \%$ \\
15 & Draga & 161.657 & 10.777 & $2,53 \%$ \\
324 & Moto niveladora & 160.929 & 497 & $2,52 \%$ \\
1.132 & Retro escavadeira & 120.028 & 106 & $1,88 \%$ \\
1.065 & Pick up & 119.287 & 112 & $1,86 \%$ \\
513 & Rolo compactador & 109.493 & 213 & $1,71 \%$ \\
610 & Guindaste & 81.883 & 134 & $1,28 \%$ \\
467 & Ônibus & 66.041 & 141 & $1,03 \%$ \\
48 & Carreta perfuração & 63.337 & 1.320 & $0,99 \%$ \\
6.796 & Outros Equipamentos & 480.395 & 9.863 & $7,51 \%$ \\
\hline
\end{tabular}


6.4 Consumo energético por tipo de caminhão [GJ]

\begin{tabular}{ccccc}
\hline Quantidade & Equipamento & Consumo [GJ] & GJ por unidade & \% \\
\hline 3.032 & Caminhão basculante & 1.106 .655 & 365 & $17,30 \%$ \\
1.301 & Caminhão & 490.302 & 377 & $7,66 \%$ \\
100 & Caminhão comboio & 171.439 & 1.714 & $2,68 \%$ \\
409 & Caminhão tanque & 211.004 & 516 & $3,30 \%$ \\
453 & Caminhão guindaste & 98.970 & 218 & $1,55 \%$ \\
587 & Caminhão betoneira & 94.557 & 161 & $1,48 \%$ \\
293 & Caminhão pipa & 61.732 & 211 & $0,97 \%$ \\
46 & Caminhão articulado & 36.606 & 796 & $0,57 \%$ \\
297 & Caminhonete & 51.428 & 173 & $0,80 \%$ \\
73 & Caminhão plataforma & 17.070 & 234 & $0,27 \%$ \\
25 & Caminhão de reboque & 4.240 & 170 & $0,07 \%$ \\
26 & Caminhão baú & 4.064 & 156 & $0,06 \%$ \\
26 & Caminhão bomba & 4.394 & 169 & $0,07 \%$ \\
62 & Caminhão cavalo mecânico & 16.319 & 263 & $0,26 \%$ \\
11 & Caminhão de lixo & 1.836 & 167 & $0,03 \%$ \\
14 & Caminhão lança concreto & 1.829 & 131 & $0,03 \%$ \\
12 & Caminhão limpa fossa & 2.811 & 234 & $0,04 \%$ \\
13 & Caminhão munck & 573 & 44 & $0,01 \%$ \\
\hline
\end{tabular}


6.5 Destinação dos combustíveis para cada tipo de equipamento [Litros]

\begin{tabular}{|c|c|c|c|c|c|c|c|c|c|c|c|c|c|}
\hline & Diesel & $\begin{array}{c}\text { Diesel } \\
\text { B20 }\end{array}$ & $\begin{array}{c}\text { Diesel } \\
\text { B5 } \\
\end{array}$ & $\begin{array}{c}\text { Diesel } \\
\text { B7 }\end{array}$ & $\begin{array}{c}\text { Diesel } \\
\text { B10 }\end{array}$ & $\begin{array}{c}\text { Diesel } \\
\text { B2 } \\
\end{array}$ & $\begin{array}{c}\text { Etanol } \\
\text { E100 }\end{array}$ & Gasolina & $\begin{array}{c}\text { Gasolina } \\
\text { E10 }\end{array}$ & $\begin{array}{c}\text { Gasolina } \\
\text { E2 }\end{array}$ & $\begin{array}{c}\text { Gasolina } \\
\text { E23.75 } \\
\end{array}$ & $\begin{array}{c}\text { Gasolina } \\
\text { E5 } \\
\end{array}$ & $\begin{array}{c}\text { Gasolina } \\
\text { E7.8 } \\
\end{array}$ \\
\hline Caminhão & 24.701 .921 & 15.648 & 33.696 .532 & 1.170 .098 & 1.302 .981 & 681.100 & - & 1.548 .082 & - & - & 6.349 & - & 22 \\
\hline Escavadeira & 5.666 .425 & - & 15.639 .855 & - & 963.637 & 813.544 & - & - & - & - & - & - & - \\
\hline Gerador & 11.768 .631 & 575 & 6.656 .052 & 210.853 & 11.038 & - & - & 21.007 & - & - & 39.518 & - & 19 \\
\hline Trator de esteira & 3.917 .039 & - & 6.574 .926 & - & 213.455 & 313.489 & - & - & - & - & - & - & - \\
\hline Pá carregadeira & 3.332 .114 & - & 3.213 .128 & 1.164 & 143.138 & 157.467 & - & - & - & - & - & - & - \\
\hline Compressor & 2.108 .192 & 360 & 3.190 .700 & 4.739 & 57.074 & 195.014 & - & - & - & - & - & - & - \\
\hline Automóvel & 491.067 & - & 267.310 & 68.132 & - & - & 298.295 & 1.005 .498 & - & 67.459 & 3.763 .559 & 54.395 & - \\
\hline Draga & - & - & 4.293 .782 & - & - & - & - & - & - & - & - & - & - \\
\hline Moto niveladora & 2.509 .124 & - & 1.427 .571 & 63.508 & 215.609 & 49.011 & - & - & - & - & - & - & - \\
\hline Retro escavadeira & 1.756 .552 & 2.408 & 1.194 .104 & 27.312 & 87.640 & 112.693 & - & - & - & - & - & - & 186 \\
\hline Pick up & 1.335 .897 & - & 902.307 & 53.199 & 353.845 & 186.952 & - & 358.290 & - & - & - & - & - \\
\hline Rolo compactador & 1.744 .684 & - & 915.761 & 70 & 174.836 & 62.757 & - & 3.692 & - & - & - & - & - \\
\hline Guindaste & 1.446 .021 & 3.513 & 668.039 & 25.990 & 25.472 & - & - & - & - & - & - & - & - \\
\hline Ônibus & 821.524 & - & 707.717 & 40.435 & 108.331 & 69.799 & - & 3.464 & - & - & - & - & - \\
\hline Carreta perfuração & 47.585 & - & 1.634 .513 & - & - & - & - & - & - & - & - & - & - \\
\hline Outros Equipamentos & 37.288 .391 & 9.929 & 12.665 .247 & 211.392 & 380.525 & 313.568 & 5.659 & 400.568 & 2.535 & - & 414.948 & - & 85.878 \\
\hline
\end{tabular}


6.6 Destinação dos combustíveis para cada tipo de equipamento [GJ]

\begin{tabular}{|c|c|c|c|c|c|c|c|c|c|c|c|c|c|}
\hline & Diesel & $\begin{array}{c}\text { Diesel } \\
\text { B20 } \\
\end{array}$ & $\begin{array}{c}\text { Diesel } \\
\text { B5 } \\
\end{array}$ & $\begin{array}{c}\text { Diesel } \\
\text { B7 } \\
\end{array}$ & $\begin{array}{c}\text { Diesel } \\
\text { B10 } \\
\end{array}$ & $\begin{array}{c}\text { Diesel } \\
\text { B2 } \\
\end{array}$ & $\begin{array}{c}\text { Etanol } \\
\text { E100 } \\
\end{array}$ & Gasolina & $\begin{array}{c}\text { Gasolina } \\
\text { E10 } \\
\end{array}$ & $\begin{array}{c}\text { Gasolina } \\
\text { E2 }\end{array}$ & $\begin{array}{c}\text { Gasolina } \\
\text { E23.75 } \\
\end{array}$ & $\begin{array}{c}\text { Gasolina } \\
\text { E5 }\end{array}$ & $\begin{array}{c}\text { Gasolina } \\
\text { E7.8 } \\
\end{array}$ \\
\hline Caminhão & 933.901 & 592 & 1.268 .646 & 43.979 & 48.849 & 25.707 & - & 53.960 & - & - & 205 & - & - \\
\hline Escavadeira & 214.229 & - & 588.828 & - & 36.127 & 30.706 & - & - & - & - & - & - & - \\
\hline Gerador & 444.934 & 22 & 250.595 & 7.925 & 414 & - & - & 732 & - & - & 1.277 & - & - \\
\hline Trator de esteira & 148.091 & - & 247.541 & - & 8.002 & 11.832 & - & - & - & - & - & - & - \\
\hline Pá carregadeira & 125.977 & - & 120.972 & 44 & 5.366 & 5.943 & - & - & - & - & - & - & - \\
\hline Compressor & 79.704 & 14 & 120.127 & 178 & 2.140 & 7.361 & - & - & - & - & - & - & - \\
\hline Automóvel & 18.566 & - & 10.064 & 2.561 & - & - & 6.719 & 35.048 & - & 2.337 & 121.592 & 1.867 & - \\
\hline Draga & - & - & 161.657 & - & - & - & - & - & - & - & - & - & - \\
\hline Moto niveladora & 94.862 & - & 53.747 & 2.387 & 8.083 & 1.850 & - & - & - & - & - & - & - \\
\hline Retro escavadeira & 66.410 & 91 & 44.957 & 1.027 & 3.286 & 4.253 & - & - & - & - & - & - & - \\
\hline Pick up & 50.506 & - & 33.971 & 2.000 & 13.266 & 7.056 & - & 12.489 & - & - & - & - & - \\
\hline Rolo compactador & 65.961 & - & 34.478 & - & 6.555 & 2.369 & - & 129 & - & - & - & - & - \\
\hline Guindaste & 54.669 & 133 & 25.151 & 977 & 955 & - & - & - & - & - & - & - & - \\
\hline Ônibus & 31.059 & - & 26.645 & 1.520 & 4.061 & 2.634 & - & 121 & - & - & - & - & - \\
\hline Carreta perfuração & 1.799 & - & 61.538 & - & - & - & - & - & - & - & - & - & - \\
\hline $\begin{array}{c}\text { Outros } \\
\text { Equipamentos }\end{array}$ & 1.409 .755 & 375 & 476.836 & 7.945 & 14.266 & 11.835 & 127 & 13.962 & 86 & - & 13.406 & - & 2.930 \\
\hline
\end{tabular}


6.7 Destinação dos combustíveis para cada tipo de equipamento [\% de litros]

\begin{tabular}{|c|c|c|c|c|c|c|c|c|c|c|c|c|c|}
\hline & Diesel & $\begin{array}{c}\text { Diesel } \\
\text { B20 }\end{array}$ & $\begin{array}{c}\text { Diesel } \\
\text { B5 } \\
\end{array}$ & $\begin{array}{c}\text { Diesel } \\
\text { B7 } \\
\end{array}$ & $\begin{array}{c}\text { Diesel } \\
\text { B10 }\end{array}$ & $\begin{array}{c}\text { Diesel } \\
\text { B2 } \\
\end{array}$ & $\begin{array}{c}\text { Etanol } \\
\text { E100 }\end{array}$ & Gasolina & $\begin{array}{c}\text { Gasolina } \\
\text { E10 }\end{array}$ & $\begin{array}{c}\text { Gasolina } \\
\text { E2 }\end{array}$ & $\begin{array}{c}\text { Gasolina } \\
\text { E23.75 } \\
\end{array}$ & $\begin{array}{c}\text { Gasolina } \\
\text { E5 }\end{array}$ & $\begin{array}{c}\text { Gasolina } \\
\text { E7.8 } \\
\end{array}$ \\
\hline Caminhão & $24,97 \%$ & $48,25 \%$ & $35,98 \%$ & $62,34 \%$ & $32,27 \%$ & $23,05 \%$ & & $46,34 \%$ & & & $0,15 \%$ & & \\
\hline Escavadeira & $5,73 \%$ & & $16,70 \%$ & & $23,87 \%$ & $27,53 \%$ & & & & & & & \\
\hline Gerador & $11,90 \%$ & $1,77 \%$ & $7,11 \%$ & $11,23 \%$ & $0,27 \%$ & & & $0,63 \%$ & & & $0,94 \%$ & & \\
\hline Trator de esteira & $3,96 \%$ & & $7,02 \%$ & & $5,29 \%$ & $10,61 \%$ & & & & & & & \\
\hline Pá carregadeira & $3,37 \%$ & & $3,43 \%$ & $0,06 \%$ & $3,55 \%$ & $5,33 \%$ & & & & & & & \\
\hline Compressor & $2,13 \%$ & $1,11 \%$ & $3,41 \%$ & $0,25 \%$ & $1,41 \%$ & $6,60 \%$ & & & & & & & \\
\hline Automóvel & $0,50 \%$ & & $0,29 \%$ & $3,63 \%$ & & & $98,14 \%$ & $30,10 \%$ & & $100,00 \%$ & $89,09 \%$ & $100,00 \%$ & \\
\hline Draga & & & $4,59 \%$ & & & & & & & & & & \\
\hline Moto niveladora & $2,54 \%$ & & $1,52 \%$ & $3,38 \%$ & $5,34 \%$ & $1,66 \%$ & & & & & & & \\
\hline Retro escavadeira & $1,78 \%$ & $7,42 \%$ & $1,28 \%$ & $1,46 \%$ & $2,17 \%$ & $3,81 \%$ & & & & & & & \\
\hline Pick up & $1,35 \%$ & & $0,96 \%$ & $2,83 \%$ & $8,76 \%$ & $6,33 \%$ & & $10,73 \%$ & & & & & \\
\hline Rolo compactador & $1,76 \%$ & & $0,98 \%$ & & $4,33 \%$ & $2,12 \%$ & & $0,11 \%$ & & & & & \\
\hline Guindaste & $1,46 \%$ & $10,83 \%$ & $0,71 \%$ & $1,38 \%$ & $0,63 \%$ & & & & & & & & \\
\hline Carreta perfuração & $0,05 \%$ & & $1,75 \%$ & & & & & & & & & & \\
\hline $\begin{array}{c}\text { Outros } \\
\text { Equipamentos }\end{array}$ & $37,69 \%$ & $30,61 \%$ & $13,52 \%$ & $11,26 \%$ & $9,42 \%$ & $10,61 \%$ & $1,86 \%$ & $11,99 \%$ & $100,00 \%$ & & $9,82 \%$ & & $99,74 \%$ \\
\hline
\end{tabular}


6.8 Destinação dos combustíveis por tipo de obra [GJ]

\begin{tabular}{|c|c|c|c|c|c|c|c|c|c|c|c|c|c|}
\hline & Diesel & $\begin{array}{c}\text { Diesel } \\
\text { B20 }\end{array}$ & $\begin{array}{c}\text { Diesel } \\
\text { B5 } \\
\end{array}$ & $\begin{array}{c}\text { Diesel } \\
\text { B7 }\end{array}$ & $\begin{array}{c}\text { Diesel } \\
\text { B10 }\end{array}$ & $\begin{array}{c}\text { Diesel } \\
\text { B2 } \\
\end{array}$ & $\begin{array}{c}\text { Etanol } \\
\text { E100 }\end{array}$ & Gasolina & $\begin{array}{c}\text { Gasolina } \\
\text { E10 }\end{array}$ & $\begin{array}{c}\text { Gasolina } \\
\text { E2 } \\
\end{array}$ & $\begin{array}{c}\text { Gasolina } \\
\text { E23.75 }\end{array}$ & $\begin{array}{c}\text { Gasolina } \\
\text { E5 } \\
\end{array}$ & $\begin{array}{c}\text { Gasolina } \\
\text { E7.8 } \\
\end{array}$ \\
\hline Rodovia & 1.309 .440 & - & 606.186 & - & 118.864 & - & - & 2.110 & - & - & 1.231 & - & 2.930 \\
\hline Hidrelétrica & 854.911 & - & 1.106 .847 & - & - & 111.548 & - & 56.109 & - & - & 36.140 & - & - \\
\hline Montagem & 343.595 & 1.226 & 1.137 .669 & - & - & - & 787 & - & - & - & 53.011 & - & - \\
\hline Saneamento & 278.628 & - & 24.460 & 38.852 & - & - & - & 896 & - & - & 56 & 1.144 & - \\
\hline Portuária & 209.147 & - & 62.629 & - & - & - & - & 9.067 & - & - & 2.145 & - & - \\
\hline Edificação & 189.970 & - & 46.820 & - & - & - & - & 13.222 & - & - & 1.309 & - & - \\
\hline Túnel & 71.471 & - & 85.051 & - & 32.507 & - & - & 6.859 & 86 & - & - & - & - \\
\hline Ponte & 132.582 & - & - & - & - & - & - & 6.843 & - & - & - & - & - \\
\hline Pavimentação & - & - & 61.846 & - & - & - & - & - & - & - & 4.775 & - & - \\
\hline Refinaria & - & - & 103.689 & - & - & - & 375 & - & - & - & 1.623 & - & - \\
\hline Viaduto & 56.139 & - & - & - & - & - & - & 2.547 & - & - & - & - & - \\
\hline Terraplanagem & 78.364 & - & 29.958 & - & - & - & - & - & - & - & - & - & - \\
\hline Estaleiro & - & - & 61.118 & - & - & - & - & - & - & - & - & - & - \\
\hline Metro & 59.579 & - & 3.227 & - & - & - & 34 & 2.952 & - & - & 1.092 & - & - \\
\hline $\begin{array}{l}\text { Concessionária } \\
\text { Rodovia }\end{array}$ & - & - & 11.775 & - & - & - & 4.192 & - & - & - & 10.799 & - & - \\
\hline Ferrovia & - & - & 59.565 & - & - & - & - & 3.845 & - & - & 2.157 & - & - \\
\hline Pedreira & 37.624 & - & - & - & - & - & - & - & - & - & - & - & - \\
\hline Rede Elétrica & - & - & 15.844 & - & - & - & - & - & - & - & 12.694 & - & - \\
\hline Escritório & 913 & - & 3.554 & - & - & - & 159 & 3.227 & - & 2.337 & 2.537 & 88 & - \\
\hline Urbanização & 80.080 & - & - & - & - & - & - & 583 & - & - & - & - & - \\
\hline Concessionária & 11.865 & - & - & - & - & - & 1.298 & 2.362 & - & - & 2.249 & - & - \\
\hline Petroquímica & - & - & 52.230 & 16.479 & - & - & - & - & - & - & - & 636 & - \\
\hline Drenagem & - & - & 26.421 & - & - & - & - & - & - & - & 2.857 & - & - \\
\hline
\end{tabular}




\begin{tabular}{|c|c|c|c|c|c|c|c|c|c|c|c|c|c|}
\hline & Diesel & $\begin{array}{c}\text { Diesel } \\
\text { B20 } \\
\end{array}$ & $\begin{array}{c}\text { Diesel } \\
\text { B5 } \\
\end{array}$ & $\begin{array}{c}\text { Diesel } \\
\text { B7 } \\
\end{array}$ & $\begin{array}{c}\text { Diesel } \\
\text { B10 } \\
\end{array}$ & $\begin{array}{c}\text { Diesel } \\
\text { B2 } \\
\end{array}$ & $\begin{array}{c}\text { Etanol } \\
\text { E100 }\end{array}$ & Gasolina & $\begin{array}{c}\text { Gasolina } \\
\text { E10 } \\
\end{array}$ & $\begin{array}{c}\text { Gasolina } \\
\text { E2 } \\
\end{array}$ & $\begin{array}{c}\text { Gasolina } \\
\text { E23.75 } \\
\end{array}$ & $\begin{array}{c}\text { Gasolina } \\
\text { E5 } \\
\end{array}$ & $\begin{array}{c}\text { Gasolina } \\
\text { E7.8 } \\
\end{array}$ \\
\hline Siderúrgica & - & - & 17.456 & - & - & - & - & - & - & - & 271 & - & - \\
\hline Gasoduto & - & - & - & 15.213 & - & - & - & - & - & - & - & - & - \\
\hline Aeroporto & 10.213 & - & - & - & - & - & - & 3.896 & - & - & - & - & - \\
\hline Barragem & 9.489 & - & - & - & - & - & - & 1.312 & - & - & - & - & - \\
\hline Plataforma & - & - & 6.614 & - & - & - & - & - & - & - & - & - & - \\
\hline Adutora & 3.899 & - & 1.184 & - & - & - & - & 612 & - & - & 645 & - & - \\
\hline Irrigação & - & - & 1.611 & - & - & - & - & - & - & - & 830 & - & - \\
\hline Dragagem & 2.512 & - & - & - & - & - & - & - & - & - & - & - & - \\
\hline
\end{tabular}


6.9 Participação no consumo energético de combustíveis para cada tipo de obra [\% de GJ]

\begin{tabular}{|c|c|c|c|c|c|c|c|c|c|c|c|c|c|}
\hline & Diesel & $\begin{array}{c}\text { Diesel } \\
\text { B20 }\end{array}$ & $\begin{array}{c}\text { Diesel } \\
\text { B5 }\end{array}$ & $\begin{array}{c}\text { Diesel } \\
\text { B7 }\end{array}$ & $\begin{array}{c}\text { Diesel } \\
\text { B10 }\end{array}$ & $\begin{array}{c}\text { Diesel } \\
\text { B2 }\end{array}$ & $\begin{array}{c}\text { Etanol } \\
\text { E100 }\end{array}$ & Gasolina & $\begin{array}{c}\text { Gasolina } \\
\text { E10 }\end{array}$ & $\begin{array}{c}\text { Gasolina } \\
\text { E2 }\end{array}$ & $\begin{array}{c}\text { Gasolina } \\
\text { E23.75 }\end{array}$ & $\begin{array}{c}\text { Gasolina } \\
\text { E5 }\end{array}$ & $\begin{array}{c}\text { Gasolina } \\
\text { E7.8 }\end{array}$ \\
\hline Rodovia & $35,01 \%$ & & $17,19 \%$ & & $78,53 \%$ & & & $1,81 \%$ & & & $0,90 \%$ & & $100,00 \%$ \\
\hline Hidrelétrica & $22,86 \%$ & & $31,39 \%$ & & & $100,00 \%$ & & $48,19 \%$ & & & $26,49 \%$ & & \\
\hline Montagem & $9,19 \%$ & $100,00 \%$ & $32,27 \%$ & & & & $11,49 \%$ & & & & $38,86 \%$ & & \\
\hline Saneamento & $7,45 \%$ & & $0,69 \%$ & $55,07 \%$ & & & & $0,77 \%$ & & & $0,04 \%$ & $61,24 \%$ & \\
\hline Portuária & $5,59 \%$ & & $1,78 \%$ & & & & & $7,79 \%$ & & & $1,57 \%$ & & \\
\hline Edificação & $5,08 \%$ & & $1,33 \%$ & & & & & $11,36 \%$ & & & $0,96 \%$ & & \\
\hline Túnel & $1,91 \%$ & & $2,41 \%$ & & $21,47 \%$ & & & $5,89 \%$ & $100,00 \%$ & & & & \\
\hline Ponte & $3,54 \%$ & & & & & & & $5,88 \%$ & & & & & \\
\hline Pavimentação & & & $1,75 \%$ & & & & & & & & $3,50 \%$ & & \\
\hline Refinaria & & & $2,94 \%$ & & & & $5,48 \%$ & & & & $1,19 \%$ & & \\
\hline Viaduto & $1,50 \%$ & & & & & & & $2,19 \%$ & & & & & \\
\hline Terraplanagem & $2,10 \%$ & & $0,85 \%$ & & & & & & & & & & \\
\hline Estaleiro & & & $1,73 \%$ & & & & & & & & & & \\
\hline Metro & $1,59 \%$ & & $0,09 \%$ & & & & $0,49 \%$ & $2,53 \%$ & & & $0,80 \%$ & & \\
\hline Concessionária Rodovia & & & $0,33 \%$ & & & & $61,24 \%$ & & & & $7,92 \%$ & & \\
\hline Ferrovia & & & $1,69 \%$ & & & & & $3,30 \%$ & & & $1,58 \%$ & & \\
\hline Pedreira & $1,01 \%$ & & & & & & & & & & & & \\
\hline Rede Elétrica & & & $0,45 \%$ & & & & & & & & $9,30 \%$ & & \\
\hline Escritório & $0,02 \%$ & & $0,10 \%$ & & & & $2,33 \%$ & $2,77 \%$ & & $100,00 \%$ & $1,86 \%$ & $4,72 \%$ & \\
\hline Urbanização & $2,14 \%$ & & & & & & & $0,50 \%$ & & & & & \\
\hline Concessionária & $0,32 \%$ & & & & & & $18,97 \%$ & $2,03 \%$ & & & $1,65 \%$ & & \\
\hline Petroquímica & & & $1,48 \%$ & $23,36 \%$ & & & & & & & & $34,04 \%$ & \\
\hline Drenagem & & & $0,75 \%$ & & & & & & & & $2,09 \%$ & & \\
\hline Siderúrgica & & & $0,50 \%$ & & & & & & & & $0,20 \%$ & & \\
\hline
\end{tabular}




\begin{tabular}{|c|c|c|c|c|c|c|c|c|c|c|c|c|c|}
\hline & Diesel & $\begin{array}{c}\text { Diesel } \\
\text { B20 }\end{array}$ & $\begin{array}{c}\text { Diesel } \\
\text { B5 } \\
\end{array}$ & $\begin{array}{c}\text { Diesel } \\
\text { B7 } \\
\end{array}$ & $\begin{array}{c}\text { Diesel } \\
\text { B10 }\end{array}$ & $\begin{array}{c}\text { Diesel } \\
\text { B2 } \\
\end{array}$ & $\begin{array}{c}\text { Etanol } \\
\text { E100 }\end{array}$ & Gasolina & $\begin{array}{c}\text { Gasolina } \\
\text { E10 } \\
\end{array}$ & $\begin{array}{c}\text { Gasolina } \\
\text { E2 } \\
\end{array}$ & $\begin{array}{c}\text { Gasolina } \\
\text { E23.75 } \\
\end{array}$ & $\begin{array}{c}\text { Gasolina } \\
\text { E5 } \\
\end{array}$ & $\begin{array}{c}\text { Gasolina } \\
\text { E7.8 } \\
\end{array}$ \\
\hline Gasoduto & & & & $21,57 \%$ & & & & & & & & & \\
\hline Aeroporto & $0,27 \%$ & & & & & & & $3,35 \%$ & & & & & \\
\hline Barragem & $0,25 \%$ & & & & & & & $1,13 \%$ & & & & & \\
\hline Plataforma & & & $0,19 \%$ & & & & & & & & & & \\
\hline Adutora & $0,10 \%$ & & $0,03 \%$ & & & & & $0,53 \%$ & & & $0,47 \%$ & & \\
\hline Irrigação & & & $0,05 \%$ & & & & & & & & $0,61 \%$ & & \\
\hline Dragagem & $0,07 \%$ & & & & & & & & & & & & \\
\hline
\end{tabular}


6.10 Consumo mediano por tipo de equipamento monitorado via satélite [l/h]

\begin{tabular}{lcc}
\hline \multicolumn{1}{c}{ Tipo de equipamento } & Número de equipamentos & $\begin{array}{c}\text { Valor mediano para consumo } \\
{[\mathbf{l} / \mathbf{h}]}\end{array}$ \\
\hline Bomba & 9 & 14,69 \\
Caminhão & 343 & 7,91 \\
Carregadeira de pneus & 28 & 8,37 \\
Carreta perfuração & 20 & 18,93 \\
Cavalo mecânico & 24 & 10,15 \\
Compactador & 26 & 8,63 \\
Compressor & 59 & 14,96 \\
Draga & 3 & 1379,00 \\
Empilhadeira & 14 & 4,16 \\
Escavadeira & 100 & 13,40 \\
Gerador & 101 & 6,47 \\
Guindaste & 37 & 6,19 \\
Manipulador telescópico & 27 & 4,20 \\
Máquina de solda & 3 & 11,48 \\
Mini carregadeira & 5 & 2,30 \\
Mini escavadeira & 7 & 2,83 \\
Misturador de concreto & 4 & 5,37 \\
Moto niveladora & 17 & 14,24 \\
Ônibus & 3 & 4,40 \\
Outros & 2 & 5,09 \\
Perfuratriz & 4 & 18,80 \\
Plataforma elevatória & 7 & 5,88 \\
Plataforma telescópica & 17 & 5,26 \\
Rebocador & 7 & 20,69 \\
Retro escavadeira & 45 & 7,10 \\
Torre de iluminação & 38 & 4,00 \\
Trator & 16 & 11,63 \\
Trator de esteira & 52 & 16,90 \\
\hline
\end{tabular}


6.11 Quantitativo de geradores por faixa de consumo em litros por hora [unidades]

\begin{tabular}{cl}
\hline Unidades de geradores & \multicolumn{1}{c}{ Consumo [1/h] } \\
\hline 37 & Entre 0 e 5 \\
28 & Entre 5 e 10 \\
9 & Entre 10 e 15 \\
6 & Entre 15 e 20 \\
3 & Entre 20 e 25 \\
3 & Entre 25 e 30 \\
2 & Entre 30 e 35 \\
1 & Entre 35 e 40 \\
1 & Entre 40 e 45 \\
0 & Entre 45 e 50 \\
0 & Entre 50 e 55 \\
0 & Entre 55 e 60 \\
1 & Entre 60 e 65 \\
1 & Entre 65 e 70 \\
1 & Entre 70 e 75 \\
0 & Entre 75 e 80 \\
0 & Entre 80 e 85 \\
0 & Entre 85 e 90 \\
0 & Entre 90 e 95 \\
0 & Entre 95 e 100 \\
1 & Entre 100 e 105 \\
1 & Entre 105 e 110 \\
2 & Entre 110 e 410 \\
1 & Entre 410 e 415 \\
1 & Entre 415 e 420 \\
1 & Entre 420 e 555 \\
1 & Entre 555 e 560 \\
\hline
\end{tabular}


6.12 Quantitativo de caminhões por faixa de consumo em litros por hora [unidades]

\begin{tabular}{|c|c|}
\hline Unidades de caminhões & Consumo $[\mathrm{l} / \mathrm{h}]$ \\
\hline 0 & Entre 0 e 1 \\
\hline 26 & Entre 1 e 2 \\
\hline 31 & Entre 2 e 3 \\
\hline 27 & Entre 3 e 4 \\
\hline 32 & Entre 4 e 5 \\
\hline 24 & Entre 5 e 6 \\
\hline 16 & Entre 6 e 7 \\
\hline 16 & Entre 7 e 8 \\
\hline 9 & Entre 8 e 9 \\
\hline 16 & Entre 9 e 10 \\
\hline 32 & Entre 10 e 11 \\
\hline 34 & Entre 11 e 12 \\
\hline 18 & Entre 12 e 13 \\
\hline 11 & Entre 13 e 14 \\
\hline 4 & Entre 14 e 15 \\
\hline 10 & Entre 15 e 16 \\
\hline 2 & Entre 16 e 17 \\
\hline 6 & Entre 17 e 18 \\
\hline 1 & Entre 18 e 19 \\
\hline 2 & Entre 19 e 20 \\
\hline 8 & Entre 20 e 21 \\
\hline 2 & Entre 21 e 22 \\
\hline 0 & Entre 22 e 23 \\
\hline 1 & Entre 23 e 24 \\
\hline 0 & Entre 24 e 25 \\
\hline 2 & Entre 25 e 26 \\
\hline 0 & Entre 26 e 27 \\
\hline 1 & Entre 27 e 28 \\
\hline 2 & Entre 28 e 29 \\
\hline 3 & Entre 29 e 30 \\
\hline 0 & Entre 30 e 31 \\
\hline 2 & Entre 31 e 32 \\
\hline 1 & Entre 32 e 33 \\
\hline 0 & Entre 33 e 34 \\
\hline 1 & Entre 34 e 35 \\
\hline 0 & Entre 35 e 39 \\
\hline 1 & Entre 39 e 40 \\
\hline 0 & Entre 40 e 79 \\
\hline 1 & Entre 79 e 80 \\
\hline 0 & Entre 80 e 90 \\
\hline 1 & Entre 89 e 90 \\
\hline
\end{tabular}


6.13 Quantitativo de retroescavadeiras por faixa de consumo em litros por hora [unidades]

\begin{tabular}{cl}
\hline Unidades de retroescavadeiras & \multicolumn{1}{c}{ Consumo $[\mathbf{l} / \mathbf{h}]$} \\
\hline 5 & Entre 1 e 2 \\
2 & Entre 2 e 3 \\
2 & Entre 3 e 4 \\
3 & Entre 4 e 5 \\
2 & Entre 5 e 6 \\
8 & Entre 6 e 7 \\
5 & Entre 7 e 8 \\
5 & Entre 8 e 9 \\
1 & Entre 9 e 10 \\
1 & Entre 10 e 11 \\
4 & Entre 11 e 12 \\
0 & Entre 12 e 13 \\
1 & Entre 13 e 14 \\
0 & Entre 14 e 15 \\
1 & Entre 15 e 16 \\
1 & Entre 16 e 17 \\
0 & Entre 17 e 18 \\
3 & Entre 18 e 19 \\
1 & Entre 19 e 20 \\
0 & Entre 20 e 21 \\
\hline
\end{tabular}

